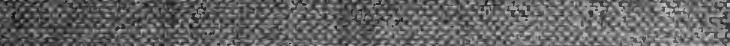

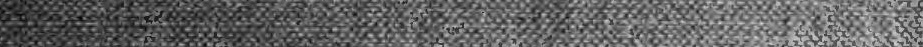
FW

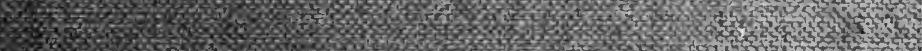

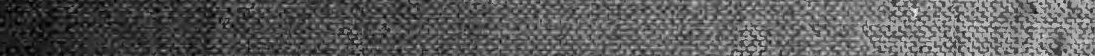

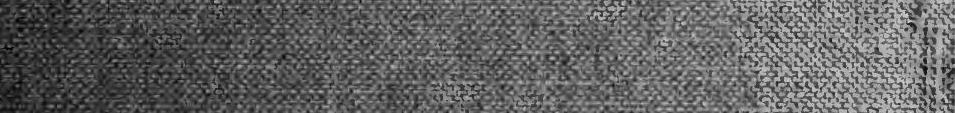

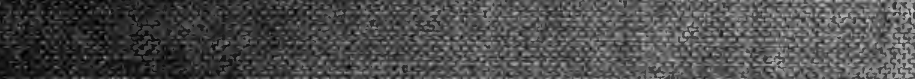

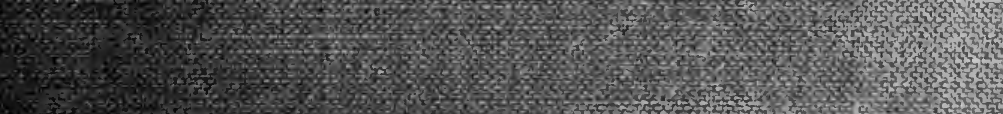
All (1)

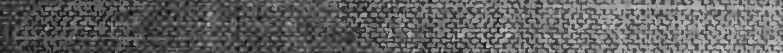

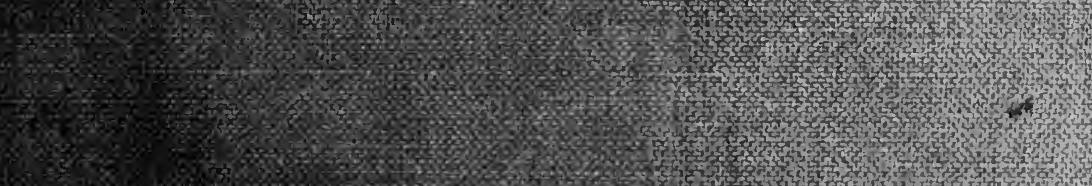
1.0. 1.

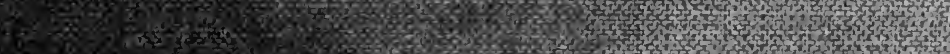

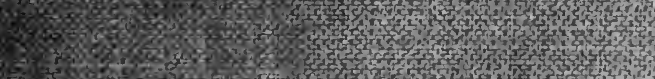

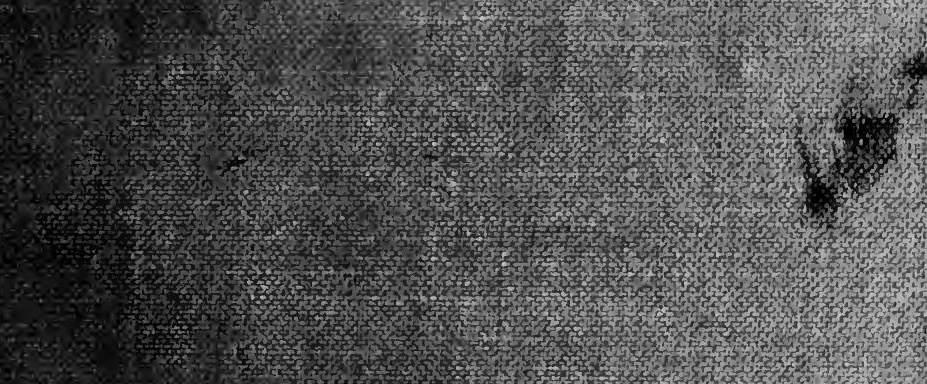
(3)

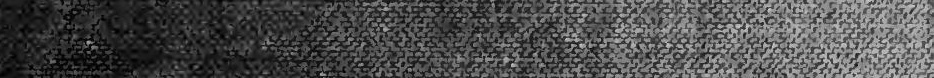

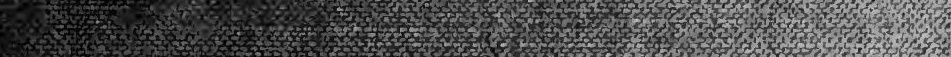

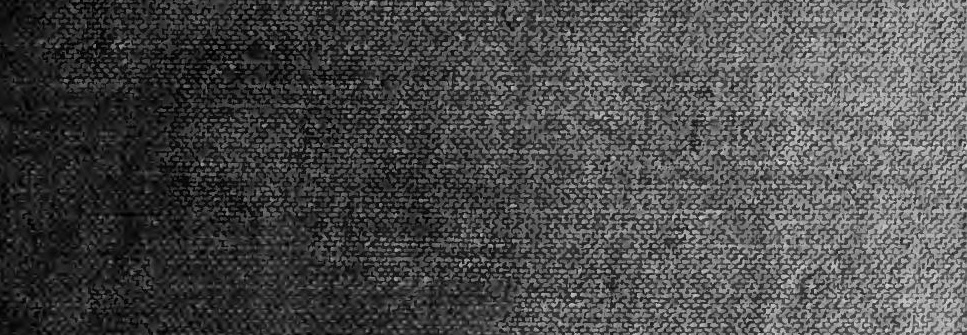

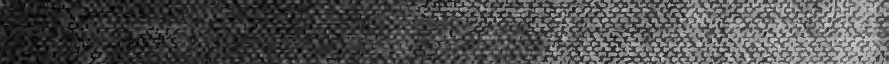
3.5. 3. 


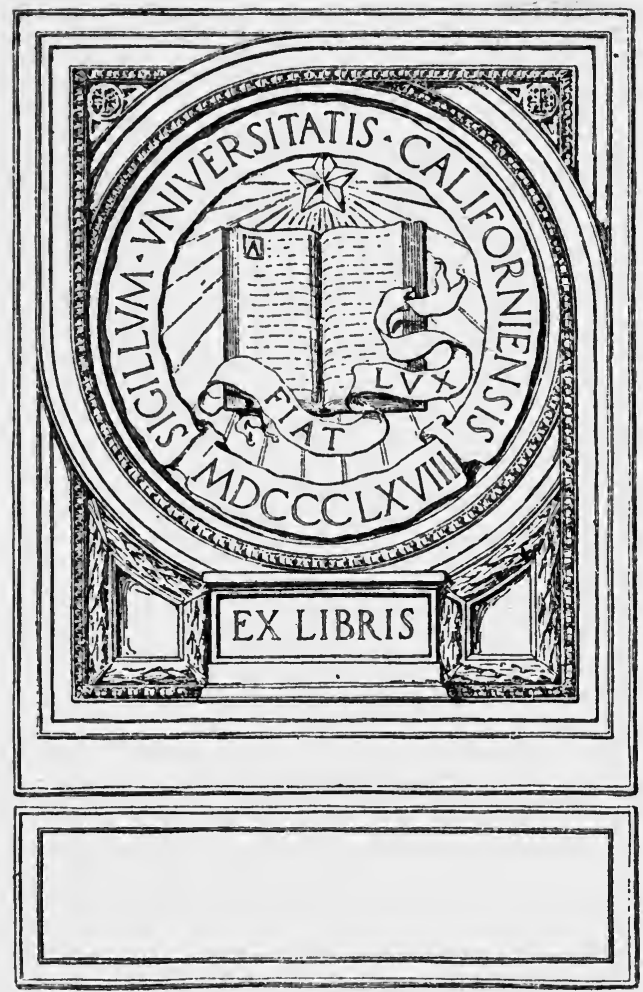


Digitized by the Internet Archive in 2007 with funding from Microsoft Corporation 



\title{
ACTUAL GOVERNMENT IN ILLINOIS
}

\author{
BY \\ MARY LOUISE CHILDS
}

Teacher of History and Civics, Evanston

Township High School

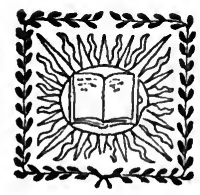

\section{NEW YORK \\ THE CENTURY CO.}

I9I7 


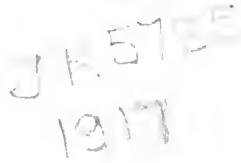

Copyright, 1914, 1917, by

The Century Co. 
TO

THE GIRLS AND BOYS

OF MY CIVICS CLASSES WHOSE INTEREST

AND LOYALTY HAVE BEEN THE

INSPIRATION OF THEIR

TEACHER 


\section{FOREWORD FOR THE TEACHER}

How may a civics teacher make vital the study of State and local government in Illinois? What are the essential facts with which the immature pupil should be familiar at the end of the course? What method of instruction will most quickly arouse his interest and give him the best training in citizenship? An earnest attempt has been made in this brief text book to suggest an answer, in part, to these important questions.

The first indispensable requisites are enthusiasm and active interest in the subject on the part of the teacher. A bored, indifferent teacher can never kindle interest or enthusiasm in the minds of high-school pupils of civics, or guide them into the broad, far-reaching fields of citizenship. The essential facts of government, particularly State and local, are dry as sawdust unless vitalized by a live teacher through connecting them at every step with the actual government in the community in which the pupils live.

Among the necessary devices to arouse interest and catch the attention is the bulletin board. Try a large one covered with dark green felt and hang it in a conspicuous place. If your pupils have access to Chicago dailies, they will be keenly interested in illustrating their note-books from the cartoons. A very interesting, instructive commentary on local and State government can be made by these cartoons. Pupils soon learn to select wisely, avoid the vulgar or simply 
grotesque, and choose the most effective ones. Try an $8 \times$ io notebook, loose leaf, with manila sheets added to the note paper for the cartoons and newspaper clippings. If you "shingle" the cartoons - slip one under the other, and paste along upper edge only - five or more can be put on one page of the manila sheet.

A "camera squad" to conduct a camera tour through the pupils' ward or village arouses much interest. Their kodaks of alleys and back yards, garbage cans, paper- and refuse-littered streets and parkways, the city "dump" or: the crematory, should be mounted and hung in the civics room where all may share the results of the "camera tour." Have them show praiseworthy conditions as well as things to criticize.

The newspaper clippings should always have noted on them name of paper, date, and an underscore in red ink or blue pencil to show why the item was cut out. This underscore saves much written explanation and is helpful in training a pupil's judgment of the essential thing in a newspaper article.

Official stationery and all kinds of official seals serve a useful purpose. A letter from some official makes that officer seem a real human being instead of a noun in a textbook, and to make this vital, human connection between text-book and actual government is the most essential part of our work. Every report, annual message, budget, ordinance, legal paper, that can be secured - and their name is legion - is grist for the civics mill.

But the human element, the meeting with officials, hear- 
ing them explain the duties of their office, the visits to institutions and buildings where they actually see the governmental wheels in motion - these are the things that seem to make the deepest impression on a pupil's mind. You may secure this vivid human illustration in several ways: by excursions of all the class (but if the class is large, all can not hear and see equally well, although they enjoy the trips in large numbers); by small groups under a pupil leadit who makes the arrangements for the party and is responsible for the group, each pupil to make an oral or written report of the trip in his own section. This method brings good results in studying your own town and saves the time of officials - sometimes the latter get a bit impatient if the individual pupils go to them, but they are glad to give some time to a group. Another method is to bring the official, as the mayor or health commissioner, to the class for a talk on their duties. If a stereopticon can be used and slides shown in illustration of the talk, so much the better.

The following excursions were given during one year for the civics class in a suburb of Chicago: A session of the Chicago council and of their own council; to the county and Federal buildings and the city hall in Chicago; to the county infirmary at Oak Forest; to Lockport via the Drainage Canal in the boat owned by the sanitary district and courteously loaned the class for that day; to the State prison at Joliet; for the boys alone, to the House of Correction; for the girls alone, to Hull House and the Crane Nursery to show how a famous social settlement is helping 
to make good citizens of aliens; a carefully chosen session of the United States district court, the docket for that day being planned six weeks in advance through the kindness of Judge Landis so the pupils might see a trial by jury; a trip to the Naval Training School at Lake Bluff and to Fort Sheridan. These excursions include the illustrative work for local, State, and National Government. They mean much work for the teacher, and every detail must be carefully planned if they are successful. But they are of great value in making vivid and practical the civics work and are well worth all they cost in time and effort. Debates and reports on suitable articles in current magazines will of course find a place in the work.

One main object has been kept constantly in mind in writing this text book: First and always to direct the pupil to the actual government in his own locality. The theory embodied in the statute and ordinance is one thing; the practical working out of the law is frequently quite a different matter; but the practical method by which the law is enforced - or not - is the vital matter to every citizen and the side of government too often neglected in our civics teaching. There is no subject taught in the high-school course where mere routine, text-book recitation, is so deadly as in civics. Therefore every effort has been made to make practical and vital the teaching of actual government within the State of Illinois.

The writer is greatly indebted to many officials for personal interviews, letters, and reports. Every courtesy has been extended to her in the work by officials in all depart- 
ments of the State and local governments. Special acknowledgment is made to the officers and director of the Chicago Bureau of Public Efficiency for permission to use their exceedingly valuable charts and reports. Mrs. Catharine Waugh McCulloch very kindly read part of the manuscript and gave the writer the benefit of helpful suggestions and criticisms.

No doubt many errors will be discovered, due to the short time allowed in preparation and the pressure of school-room duties. Much is purposely omitted that usually finds place in a civics text book. But the purpose of the book as expressed in its title has been ever in mind. It is not intended in any sense for a manual, and only points a way, tested for many years in large classes of pupils in a suburban high school, to arouse keen interest in the vital matters of home government.

A Russian Jew said to the writer recently, "You are a patriot because you teach of the government!" If all of us to whom are given the honor of guiding these junior citizens of Illinois in their first steps in citizenship could always be mindful of that fact, would not our work be ennobled immeasurably? On our faithful, intelligent efforts will depend in large degree the progress Illinois will make in wise, humane, efficient government. We can so vitalize and clothe with flesh the dry bones of civic facts that our pupils will count their study of State and local government the most human, intensely alive subject in all the high-school curriculum. Is not the end worth all the effort? 



\section{FOREWORD TO THE EDITION OF 1917}

No practical method of keeping a textbook in civics up to date has yet been evolved. A "loose-leaf" collection of printed lessons easily and economically exchangeable for new ones each year as governmental facts and devices for teaching the same evolve seems to be the only possible method of keeping pace with civic progress. But no one has yet come forward with such a series of lessons suitable for Illinois and therefore our textbooks on state and local government must be reprinted at frequent intervals if we would keep them within sight of present conditions.

From the printer's standpoint - an important one - it proved impossible to incorporate in the text the principal changes in city, county and state government within Illinois made during the last three years, or to include all these changes in footnotes. Therefore they have been gathered mainly in Appendix D at the end of the volume where it is hoped teachers, pupils and others using the book will avail themselves constantly of these collected notes and additions to the text. Illinois has been making progress during the last three years and particularly in the social legislation written on her statute books.

The new law for the care of the feeble-minded, the great increase in parks and playgrounds, the wider use of school buildings and equipment for the social needs of their districts and the steady growth of the movement to " pull Illinois out of the mud" through a fine system of highways xiii 


\section{xiv FOREWORD TO THE EDITION O I9I7}

are all proofs of the dawn of a new social conscience in our state.

When Illinois' greatest need is met,- a new constitution adapted to twentieth-century conditions, - no reprint of a textbook like this one will do, but there must be an entire revision based on the new instrument of government. 


\section{4}

\section{CONTENTS}

CHAPTER

I Cities and Villages • • • • • • • • • 3

II Government of Chicago • • • • • • • I6

III Towns AND Townships IN IllinoIs • • • 54

IV County Government in Illinois • • • • • 65

V The Public Pocketbook: How It Is Filled . 88

VI Elections and the Ballot . • • • • • 99

$\checkmark$ VII Judicial Trials and the Jury System • • . II3

VIII State of Illinois: Physiography and History 126

$\checkmark$ IX The General Assembly . • . . . . . I38

X Executive • • • • • • • • • • • • I5I

XI State Judiciary • • • • • • • • • • I59

XII Public Education in Illinois . • • • • . I65

XIII The Merit System in Illinois • • • • 175

XIV State Charity Service . • • • • • • . 188

- XV Amendment of the Illinois Constitution • . I98 XVI Illinois Moving Forward • • . • • • . 201

Appendix A-Reference List of Books and PamPhlets Valuable for Study of "Actual GovernMENT IN IllinOIS" . • • • • • • • • • 215 Appendix B - Valuable Publications of Civic OrGanizations in Chicago • • • • • • • . 217 Appendix C - Vital Statistics Law . • • • . . 219 Aprendix D-General Notes . • • • • • 222

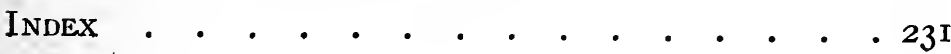



ACTUAL GOVERNMENT IN ILLINOIS 
, 


\title{
ACTUAL GOVERNMENT IN ILLINOIS
}

\author{
CHAPTER I \\ CITIES AND VILLAGES
}

REFERENCES :

I. Revised Statutes (1915-'16), ch. xxiv.

(This general law for cities and villages covers 229 pages in' the Revised Statutes of Illinois, not including the Session Laws for 1913-15.

2. Greene: Government of Illinois, pp. IoI-106.

3. Garner: Government in the United States, pp. 25-56; Government of Illinois, pp. 55-60, rev. ed.

The city corporate touches the life of the people more intimately than any governing body in the world. To speak of just one factor in its varied relations with the people, notice its streets, the "arteries through which flow the life-blood of the city - trade and traffic." "Here persons of all ages and all tastes go to meet one another, to talk over the affairs of the day, to be entertained, to eat, to drink, to inspect shop windows, to do marketing, to buy and sell merchandise, and to perform a thousand offices which the needs of the city life make profitable, healthful, or agreeable." "Then consider the influence of the streets on the habits of the people. In the congested areas of the city, the people must spend a large portion of their leisure 
on the streets, because their homes are too small for comfort, and if the city allows the streets in these sections to remain unkempt and dirty, the homes bordering them will reflect the dirt and grime of the city highway, inevitably much more, should that 'highway' be an unpaved alley." (Beard: American City Government, pp. 242-244.) And the city streets represent only one small segment of the great circle of the city powers surrounding city homes.

Are you familiar with the poster, "Madame, Who Keeps Your House?" issued by the Woman's City Club of Chicago, I 6 South Michigan Avenue? If not, make its acquaintance, for this famous poster has nearly circled the globe since it was published 4 years ago to illustrate pictorially the intimate relation existing between the city hall and the home. "The poster contains a large ' $\mathrm{C}$ ' made up of fifteen pictures illustrating the city departments that touch the home; in the center are the words, 'City Hall,' surrounded by a small ' $c$ ' made up of the names of the city departments illustrated. Below are these words: "The homely activities of your daily life make necessary these departments in the government of the city in which you live. Its interest in you is personal and kindly. Make your interest in it vital and helpful. Educate yourself in civic affairs." Know your own city!

What is the organization in Illinois of this city government that affects the daily life of its citizens so powerfully?

Cities. There are over one thousand cities and villages in Illinois. The present State constitution of 1870 forbids special legislation of any kind except for Chicago in a few definite cases, provided by recent amendment to the constitution. Therefore, in 1872, the General Assembly passed a law known as the Cities and Villages Act, for the 
government of municipalities in the State, if they chose to come under its provisions. Only about seventy-five cities, towns, and villages preferred to retain their original special charters granted by the Legislature before 1870 . The rest by vote have adopted the Cities and Villages Act, and it has therefore become their charter. This general law covers about two hundred forty pages in the Revised Statutes of Illinois and carefully details what a city may do, and provides the general framework of city government.

Much ingenuity has been displayed by the legislators in framing laws needed for a city like Chicago and a county like Cook yet not wanted in other cities and counties of Illinois. The favorite device is to put cities and counties into classes according to population and so arrange the groups that Chicago and Cook County will each come into a class by itself. "For cities having over 350,000 population" (only Chicago), or " counties having over I25,000 population" (only Cook), is frequently the wording of some law intended to apply to Chicago and Cook County alone. So far the supreme court has generally sustained such laws on the ground of necessity, although they plainly violate the spirit of the State constitution while obeying the letter.

Organization of a City. Any territory in Illinois not less than four square miles in area, having at least one thousand inhabitants, may petition the county judge (probate judge if the county has one) for a special election to vote on a city organization.

City OfFicers. If carried, the people elect a mayor, aldermen, clerk, treasurer, city attorney, and police magistrate. The wards into which the city is divided must number not less than three or more than thirty-five, depending on population, and two aldermen are chosen from each 
ward, one each year. The term of office is two years except that of the police magistrate, who is elected for four years. The aldermen are paid from three to ten dollars per session except in Chicago. ${ }^{1}$

There are over a hundred powers granted the council in the Cities and Villages Act, so its power is ample to do whatever is necessary for the city. The mayor and other officers have the same powers given under Chicago. ${ }^{1}$ The mayor, with the consent of the council, may appoint a city collector, to have charge of special assessments, special taxes for local improvements levied on property benefited, as for paving a street or putting in a sewer; a commissioner of public works to care for streets, alleys, sewers, water system, garbage collection, city buildings; corporation counsel to be legal adviser of the city officials; comptroller to have general oversight of all city accounts and expenditures; chief of police, health commissioner, fire marshal, whose names explain their work. If the city so orders through a special vote, a civil service commission of three members is also appointed by the mayor with the consent of the council to conduct the examinations required for all city employees, like policemen and firemen, who are placed in the classified service. Any of these appointed officers may be elected if the council pass an ordinance to that effect. All the officers allowed for governing a city in Illinois are named in the General Municipal Act of the State.

Commission Plan of City Government. By a law in effect in I9IO, cities not over 200,000 in population may, through a special election, adopt the commission plan of government, electing a mayor and four commissioners at large to have charge of the city. This act is applicable to

1 Chap. ii, pp. 20-22. 
all the cities in the State except Chicago, and about thirty odd have adopted it, Springfield, Rock Island, Elgin, Decatur, Cairo, and Waukegan, among the number. The five commissioners elected serve for four years and are called the council. The commissioner known as the mayor presides at all their meetings and has charge of the department of public affairs. There are five departments created by the law: (I) Public Affairs, (2) Accounts and Finances, (3) Public Health and Safety, (4) Streets and Public Improvements, (5) Public Property.

The five commissioners determine by majority vote what duties shall be vested in each department and which commissioner shall be its head. The mayor does not have the veto power. The council appoints all city officers needed; civii service is provided for all employees. To prevent abuse of power by the commissioners, they may be recalled at any time by a majority vote at a special election. The initiative and referendum are also provided to allow the voters directly to initiate and pass any necessary law. All franchises granted public service companies must be approved by the people before going into effect. Provision is made to discontinue the commission government if the voters are dissatisfied after trying the plan.

The Chautauquan Magazine (Vol. LI) has an excellent symposium on "Commission Government for Cities." In the Debaters' Handbooks is a volume devoted to commission government.

City Manager. The most recent innovation in city government is the city manager, an appointed officer who looks after the city's business exactly as a general manager directs the affairs of a private concern. River Forest in Cook County experimented with this new kind of city 
official but petty politics caused him to resign. It is claimed he considerably more than saved his year's salary through careful supervision of the village work. The experiment is being watched with great interest and seems full of promise for more efficient city government.

Director of Public Safety. Another experiment in municipal government is director of public safety, who has charge of the three principal municipal departments, health, fire, and police. Evanston has experimented with such an official (during 19I3-I5), and he worked for fire prevention, better sanitary conditions through a clean-up campaign, bakeries classified according to cleanliness, and to make every policeman a health officer, so there could be stricter enforcement of all sanitary regulations. (I) This combining the great public safety departments of a city is another step toward simpler municipal government because the chief of police, health commissioner, and fire marshal are put under civil-service rules, and the city gets one responsible officer instead of three.

City Courts (Rev. Stat., ch. xxxvii, sec. 240-363. Act amended I909.) Any city having a population not less than three thousand may establish a special city court if the voters so elect. The jurisdiction of this city court will be the same as the State circuit court. There can be from one to five judges according to population, and the salary is paid from the State treasury. The term is four years and the judge must not be chosen at the same time with other city officers. Why? Nineteen cities in Illinois have adopted this city court. The justices of the peace are retained for petty cases in cities having a special city court; but there is no police magistrate.

Village Government. (Rev. Stat. (I9I5), chap. xxiv, 
sec. I78-193.) A village government differs from a city in being more simple and therefore less expensive. It has no wards. Any area, not less than two square miles, containing at least three hundred inhabitants, if it is not already within a village or city, may be incorporated as a village by vote of the people at a special election and must thereafter remain a village until it has a thousand inhabitants, when it has the privilege, if the voters desire, of changing to a city government. There are now (9I6I) about eight hundred villages in Illinois.

I. Legislative Branch of the Village Government. ${ }^{2}$ Board of Trustees - a president and six trustees elected for two years with power of a mayor and council in passing the village ordinances.

II. Executive and Administrative Officers.

I. President - elected for two years; has same veto power as a mayor.

2. Village clerk - elected for one year.

3. Treasurer, street commissioner, board of health, village marshal, and other administrative officers appointed by the president and board of trustees.

III. Judicial Branch.

Police magistrate - one only unless more are authorized by special acts. No police magistrate can also act as justice of the peace, although his jurisdiction is the same.

\section{OUTLINE GOVERNMENT OF A CITY IN ILLINOIS}

I. Organization.

a. Petition to county (or probate) judge for special election to decide question city government.

b. First election city officers: Mayor, aldermen, clerk, treasurer, attorney, police magistrate.

2 Greene: Government of Illinois, p. 268. 
c. "Cities and Villages Act," passed Legislature 1872, becomes city's charter. Seal is granted by secretary of state at Springfield.

II. Boundaries; number of wards and precincts.

III. Time of election.

IV. Term of office.

V. Legislative Department.

A. Council composed of mayor and aldermen.

I. Duties.

a. Levy taxes.

b. Confirm or reject appointments mayor.

c. Provide police, fire, health protection.

d. Grant franchises.

e. Provide for public highways and sidewalks.

f. Provide for street cleaning, lighting; water supply, garbage removal, etc.

2. Salary.

VI. Executive Department.

A. Mayor. Who? When elected?

I. Duties.

a. Preside council meetings.

b. Vote in case of tie.

c. Sign or veto ordinances: may veto separate items in appropriation ordinance, or annual budget. Veto overcone by two-thirds vote council.

d. Send annual message to council.

e. Appoint officers consent council.

f. Issue proclamations.

g. May pardon any violation of ordinance or remit any fine imposed for such violation.

2. Salary. Find from city budget.

B. Clerk. Who? When elected?

I. Duties.

a. Keep minutes council meetings.

b. Keep seal and all important papers. 
c. Post ordinances and notices.

d. Issue licenses and permits by order Mayor.

2. Salary.

C. Treasurer. Who? When elected? Amount of bond?

r. Duties.

a. Charge of all city funds except special asses:ments.

b. Acts as town collector for general taxes.

2. Salary.

D. City Collector. Who? When appointed? Amount of bond?

I. Duty.

a. Receives special assessments or special city taxes for some particular improvement, to be paid by property benefited; as a street paved or sewer put in. Also fees for licenses and permits.

2. Salary.

E. Comptroller. Who? When appointed?

"Watch-dog of the city treasury."

r. Duties.

a. Audits all accounts of treasurer.

b. Furnishes estimates expenses for every department of city government.

2. Salary.

F. Commissioner Public Works. Who? When appointed?

I. Departments under his supervision.

a. Water works.

b. Streets and alleys.

c. Walks and cross walks.

d. Public parks; playgrounds; parkways. (Sometimes controlled by an elected park board.)

e. Public buildings, city hall, library, fire and police stations, etc.

f. Street lighting.

g. Sewers.

2. Salary. 
G. Health Commissioner? Who? When appointed? I. Duties.

a. Inspects water, milk, ice, meat, plumbing.

b. Attends to quarantine notices.

c. Is responsible for fumigating houses after contagious disease.

2. Salary.

H. Fire Marshal. Who? When appointed?

I. Duties.

a. Charge of firemen, who are often under civil-service rules.

b. Charge of police force needed in any quarter where there is fire.

2. Any salary?

I. Chief of Police. Who? When appointed?

I. Duties.

a. Keeps the peace and protects all citizens.

b. General control of policemen, who are often under civil service.

2. Salary.

J. Library Directors. Nine. How chosen?

I. Duties.

a. To manage free public library.

b. To appoint librarian and assistants.

c. To purchase all books.

d. To make rules and regulations for use of library.

2. No salary.

K. Civil Service Commission. Three. How chosen?

I. Duties.

a. To conduct examinations for policemen, firemen, library cadets, clerks, and stenographers employed by the city.

b. To certify standings of those on eligible list to the appointing officer.

2. Any salary? 
VII. Judicial Department.

A. Police Magistrate. Who? When elected?

I. Duties.

a. To try all violations ordinances.

b. To examine any case and bind person over to grand jury.

2. Salary.

B. City Attorney. Who? When elected?

I. Duties.

a. Prosecutes and defends lawsuits for the city.

2. Salary.

C. Corporation Counsel. Who? When appointed?

r. Duties.

a. Legal adviser for city officers.

b. Draws up ordinances, if so requested.

c. Draws contracts, leases, deeds, all legal papers for city departments.

2. Salary.

\section{ILLUSTRATIVE MATERIAL NEEDED}

I. Copy of Revised Statutes of Illinois, edition I9I5 if possible.

2. Copy city charter if one has been granted.

3. Copy of city ordinances.

4. Map of city showing wards and precincts. (Indispensable.)

5. Maps of separate wards. If these can not be had, make your own blue prints from regular map of city. Or use tracing paper to get your separate ward maps. On these mark all government buildings, as fire and police stations, schoolhouses, library station, small parks, and field houses.

6. Get the statistics from the Health Department and make "spot maps" showing where death rate was highest during the last year, and why. These ward maps can be used in various ways to illustrate municipal and social facts.

7. City manual for complete list of officials and their terms.

8. Impression of city seal.

9. Bulletin board for newspaper clippings and cartoons. Illus- 
trate every point possible by some recent fact in your city government. . Study your local papers to find these illustrations.

Io. Have you a camera? Form a camera squad and take a "camera tour" through your ward and the city. Photos of the alleys, parks, waterworks, your city dump, the garbage crematory, or the reduction plant will be valuable comments on your city government.

\section{PERTINENT QUESTIONS}

I. Compare the organization of your city with the one outlined in the text. You should know the name of every elected and appointed official in your city. (2) Why?

2. Make out a list of the services performed by the National, State, and municipal governments respectively. Which government touches your daily life most closely?

3. Some citizens declare they never vote at a city election; only at the State and National. What is your opinion' of such a citizen? Give three reasons for your answer.

4. Bryce says that city government is the "blackest spot" in American politics. Why?

5. Why should municipal elections be absolutely non-partisan? How can they be made non-partisan?

6. What societies, clubs, and organizations are at work in your city to make it a better place to live in? How can you help them?

7. Does your city have a civil-service commission? If so, what employees are covered by its examinations?

8. What public utilities are owned and operated by your city? If none, then what are the terms made by the franchises granted the private companies furnishing your gas, water, electric light, and street-car service? Do these companies pay the city for the privilege of using the streets, which are the property of the people? If not, why? How long do these franchises run?

9. How does your city dispose of garbage and all kinds of household and factory waste?

I0. What kinds of business does your city license? How would you secure a license? What would you have to pay for it? (Consult the Revised Ordinances.) 


\section{CITIES AND VILLAGES}

II. Does your city need a city manager? (3)

12. What are the advantages in the commission plan of city government? What disadvantages? Would it be a good thing for your city? Give reasons. 


\section{CHAPTER II \\ GOVERNMENT OF CHICAGO}

\section{REPERENCES :}

I. The Chart of the Organization of the Government of Chicago, prepared by Chicago Bureau of Public Efficiency, p. 25. All their charts are of very great value for accuracy.

2. Chicago City Manual, I9I5.

3. Efficiency Charts prepared by Civil Service Commission to show organization of all city departments.

4. Rev. Stat., I9I5, ch. 24.

5. "History and Gov. of Chicago." Educ. Bi-Mo., Chicago Normal College.

Our Civic CREed. "Chicago does not ask us, her citizens, to die for her welfare; she asks us to live for her, and so to live, and so to act, that her government may be pure, her officers honest, and every corner of her territory shall be a fit place to grow the best men and women who shall rule over her."-Adapted from a Wisconsin City.

"Where 'we will,' there's a way."-Chicago's new motto.-From The Tribune.

Early History of Chicago. The famous treaty of Greenville (I795) made by the United States with the western Indians, ceded a tract of land six miles square a congressional township - at the mouth of the Chicago river, to the Government. No use was made of this cession until the winter of $\mathrm{I} 8 \mathrm{O} 3$, when Fort Dearborn was built at the mouth of the river. A tablet marking the site of the fort has been placed on a building at the foot of Rush Street bridge. The Chicago Historical Society has a good model of the fort. Most of the land once occupied by the 
old fort is now the bed of the Chicago river. There is great difference of opinion over the meaning of the word "Chicago," but none over its Indian origin. It was probably derived from the Indian word for the "wild onion" that flourished over the prairies and marshes around the lake. Consult J. S. Currey's History of Chicago, Vol. I, pp. 32-34.

The first town of Chicago contained less than half a square mile. It lay between State, Madison, Desplaines, and Kinzie Streets. The present city contains I99 square miles (I) and extends over twenty-five miles north and south, and from nine to fourteen miles east and west. The city has grown to this wide territory through various annexations. In addition to this surface expansion, Chicago has "partially built itself up out of the marsh and is now about fourteen feet higher than the original level." This fact has an important bearing on the ever-present drainage problem and makes it a little easier to provide an adequate sewer system for the city.

Chicago was incorporated as a town in 1833 because the United States Government had just removed the last Indians from Illinois, thus throwing open the land around Chicago freely to white settlers. The birthday of the city was March 4, I837, as its seal testifies. The population was 4 , I 70 .

Government of Chicago. Because Chicago is now the second largest city in the United States and the fourth in the world - only London, New York, and Paris are larger - and because it contains more than one-third the population of Illinois, every citizen of the State should feel pride in this great city and be interested in knowing how it is governed. 
No Special Charter. The constitution of 1870 forbids special legislation of any kind. In consequence, the "Cities and Villages Act" was passed by the Illinois General Assembly, I872, and all cities organized since that date come under the provisions of this general law and do not have any separate city charter.

Chicago voted to accept this municipal corporation act in 1875 and thus gave up its charter after forty years' experience with government under various special charters.

The Council. Chicago's is one of the best examples in the United States of a powerful city council. It is a councilgoverned city. This legislative body is made up of seventy aldermen, two elected from each of the thirty-five wards. The ward bodies are determined by population, and the areas differ greatly. About 70,000 people live in a ward since the reapportionment of December 4, I9II. Get a map of Chicago, with wards and precincts marked, from the Bureau of Maps, in the city hall. Also a separate map of your own ward. The term of office of the aldermen will be four years beginning in April, I9I4, if the voters at that election accept the law passed by the last Legislature increasing the term from two to four years. (2)

The mayor presides over the council, but has a vote only in case of a tie. He has much less power than the council, and even the powers he has are limited in several ways by that body. If the personal influence of the mayor is great, he may be able to persuade enough aldermen to vote for ordinances he favors to put them through. But the council can control matters if they will. The greater power is theirs. The municipal act of 1872, many times amended, enumerates over a hundred powers granted a city council.

SEssions. The council meets regularly every Monday (3) 
afternoon at two o'clock in the council chamber of the city hall. The council sessions are open to the public, and every citizen ought to attend frequently and notice how the aldermen from his ward vote on important ordinances. They are paid $\$ 3,000$ salary and do their work largely through standing committees. To listen intelligently at a councilmeeting one needs to know the regular or routine order of business :

I. Roll call of aldermen by wards.

2. Reading of the minutes of the last meeting.

3. Messages from the mayor and reports from heads of departments.

4. Presentation of new business by wards, including introduction of ordinances.

5. Reports from committees.

6. Unfinished business.

The Committees. (4) On request you can get from the city clerk a card containing the names of all the aldermen by wards, and all the standing and special committees of the council. Every pupil should have one of these cards for reference. Also get a copy of the proceedings of the latest council meeting. The names of these committees tell their work: Finance, charge of the city budget - for 1916, $\$ 72,384,987$. All bills against the city must be approved by this committee and its chairman is the mayor's spokesman on the floor of the council-chamber. (5) $\mathrm{He}$ is paid $\$ 6,000$ a year and has to give his entire time to this important work. Committee on local transportation looks after matters of street-car service, such as through routing of the elevated cars and lengthening the platforms in the loop district; license, judiciary, streets and alleys, building, health, 
fire, police, harbors and bridges, water, taxes, civil service; gas, oil, and electric light, and elections, complete the list of standing committees. There are three special committees now on bathing beaches and piers, small parks, and compensation. The latter looks after the pay the city receives for franchises, permits, and licenses, or special privileges of any kind granted a corporation or private citizen. As Chicago received nearly one million dollars in revenue in 1915 from these sources, the committee's work is needed.

The Budget. The passing of the appropriation ordinance, or city budget ( 6$)$, in January annually, is one of the most important acts of the council. The budget is based on the estimates of the comptroller after each item has been thoroughly considered by the finance committee and given their recommendation. The vote of the council on the budget must be by roll call. In fact, the passing of every ordinance requires a roll-call vote. The council is restricted by law to a debt limit of 5 per cent. and a taxation limit of 2 per cent. on the assessed valuation of all the taxable property in the city. Any expenditure of money at any time also requires the same recorded vote. The diagram, "Chicago's Pocketbook," shows how the public pocketbook is emptied.

Executive Officers. ThE Mayor. Chicago elects the mayor, seventy aldermen, the city clerk, and treasurer. "The mayor is elected by the people, to serve the people" for a term of four years. His salary is $\$ 18,000$ a year.

His powers.

A. As chairman of the city council he may approve or veto its ordinances (may veto separate items in an appropriation bill and approve the rest). But a two-thirds vote 


\section{Chicago's Pocket Book. WHERE THE TAXES GO.}

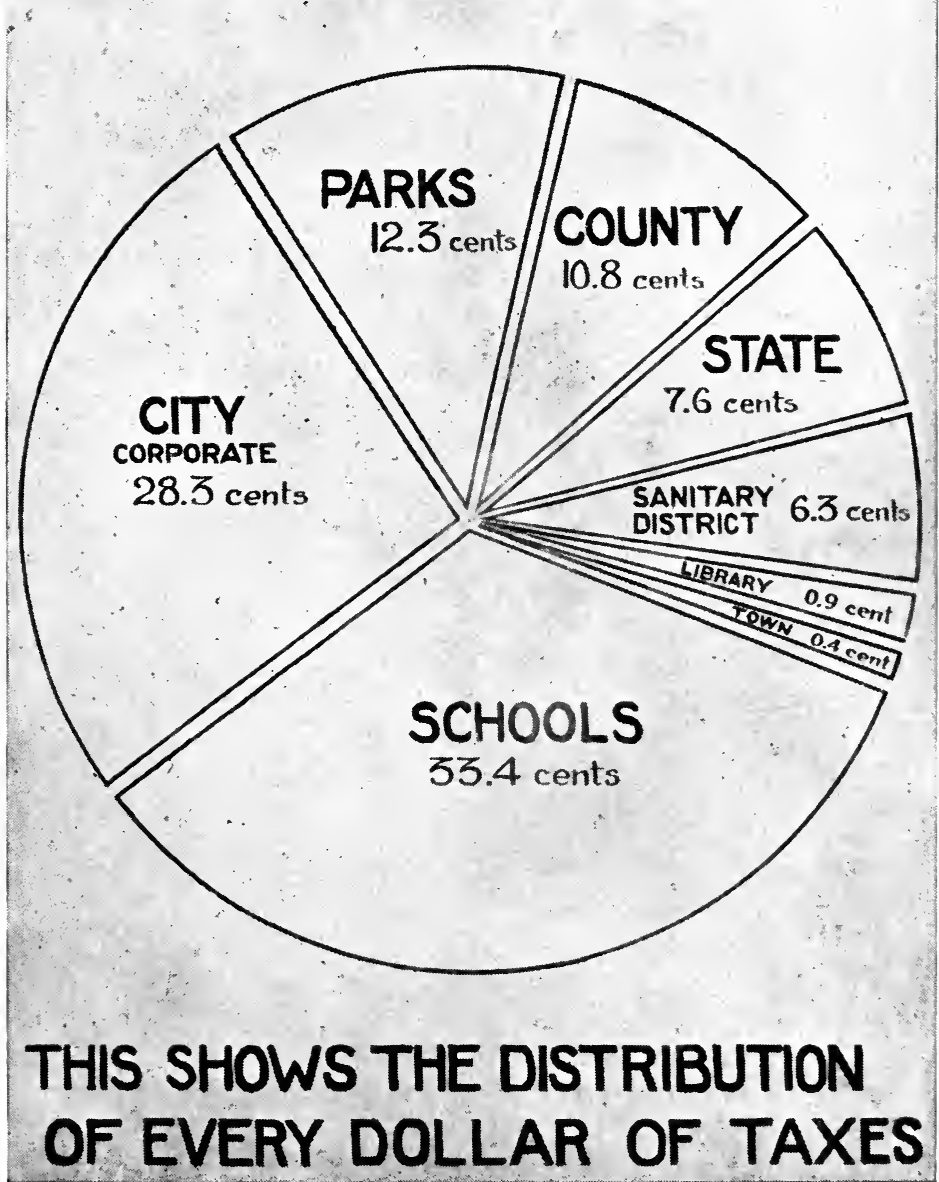


will defeat a veto and make the ordinance law. Through written messages to the council he recommends any measures he wishes considered. He is limited to five days in considering an ordinance.

B. He appoints almost all the executive officers of the city, although his power is greatly limited by the civil-service law and the consent of the council. His appointing power is now limited to about fifty positions, mainly heads of departments, exempt from the civil service. Yet his patronage, measured by the combined salaries of all the officers and employees he appoints and the powerful patronage through the street department in hiring men and teams for street work, amounts to thousands annually. One can easily understand why an ambitious politician might covet the mayoralty of Chicago.

C. He issues and revokes licenses. The exercise of this power too often links the mayor's office with the liquor interests, and the resorts of the underworld.

D. He may pardon any violation of an ordinance and remit any fine levied as a punishment.

E. He has general supervision over all city departments.

$\mathrm{F}$. $\mathrm{He}$ is conservator of the peace and responsible for the safety and order of the city through his control of the public departments.

G. He must enforce all ordinances impartially. (7) This duty is the best test of an able mayor and a good city government.

The mayor appoints the heads of the following principal departments: library board of nine directors; board of education of twenty-one members; board of three directors for the Municipal Tuberculosis Sanitarium (all these serve without pay and have the right to levy separate taxes); law 
department, including corporation counsel and city attorney; department of finance, including comptroller and city collector; general superintendent of police and two deputies; civil-service commissioners; fire and health departments; city physician; building commissioner; department of boiler inspection; weights and measures; smoke inspection; department of supplies under business agent; transportation; track elevation; department of public works; of electricity; special park commission and the city forester; board of local improvements; board of examining engineers; harbor and subway commission; superintendent and three inspectors for House of Correction ; inspector of oils ; bureau of statistics. To simply read over this list of departments and remember it takes an army of 24,000 men and women employees to attend to the city's business gives one a little idea of the big problems to be solved in running Chicago's government. For a thorough knowledge of the organization of all these departments, the positions exempt from civilservice examinations, those under the classified service, number of employees, salaries, and appropriations for I9I 5, consult the charts prepared by the Efficiency Division of the Chicago Civil-Service Commission. These charts are very valuable, but too complicated for the average citizen to understand. The admirable "Chart of the Organization of the City of Chicago," prepared in October I9I3, by the Chicago Bureau of Public Efficiency, 3 I 5 Plymouth Court, and reproduced on p. 25, gives a clear, definite idea of the organization of this great city government.

The City Clerk, elected for two years, keeps the city seal, all minutes of council meetings, lists of licenses and permits issued, and franchises granted by the council. $\mathrm{He}$ is custodian of all city papers, including the ordinances. 
$\mathrm{He}$ is the only city official not required by law to make an annual report to the mayor and council. (One solitary report was made voluntarily, 1908, by the city clerk, but the excellent precedent then set has never been followed.)

More than ninety different licenses are issued by the city clerk, varying from permission to sell gasoline, ice, or liquor, to the right to collect junk. The fees required for these licenses are paid to the city collector, but the license and metal tag often required are issued by the clerk.

The City Treasurer is elected for two years; receives $\$$ I2,000 salary; must give a bond ( I9I $5, \$ 5,000,000$ ), determined by the council. He is responsible for all the city funds, including the school taxes - in I9I6 over seventytwo million dollars. By act of the Legislature, I9I3, a term of the city clerk and the treasurer of Chicago has been increased to four years if the voters approve at the regular April election in 19I4. (9)

LAw Department. It takes a group of more than seventy attorneys and an office force of over one hundred to control the law business of the city. At their head is the Corporation Counsel, who is the chief legal adviser of the mayor, the council, and all the city officials. His salary is \$10,000. The entire legal department is exempt from any civil-service examination and the appointments are purely political.

The Business Agent is responsible for buying all supplies, from office stationery to hay for the city's horses. He must give a bond for the faithful performance of his duties. Every city officer and employee is put under a bond to guarantee good service.

BoARd of Local Improvements has five members appointed by the mayor with the consent of the council. It 


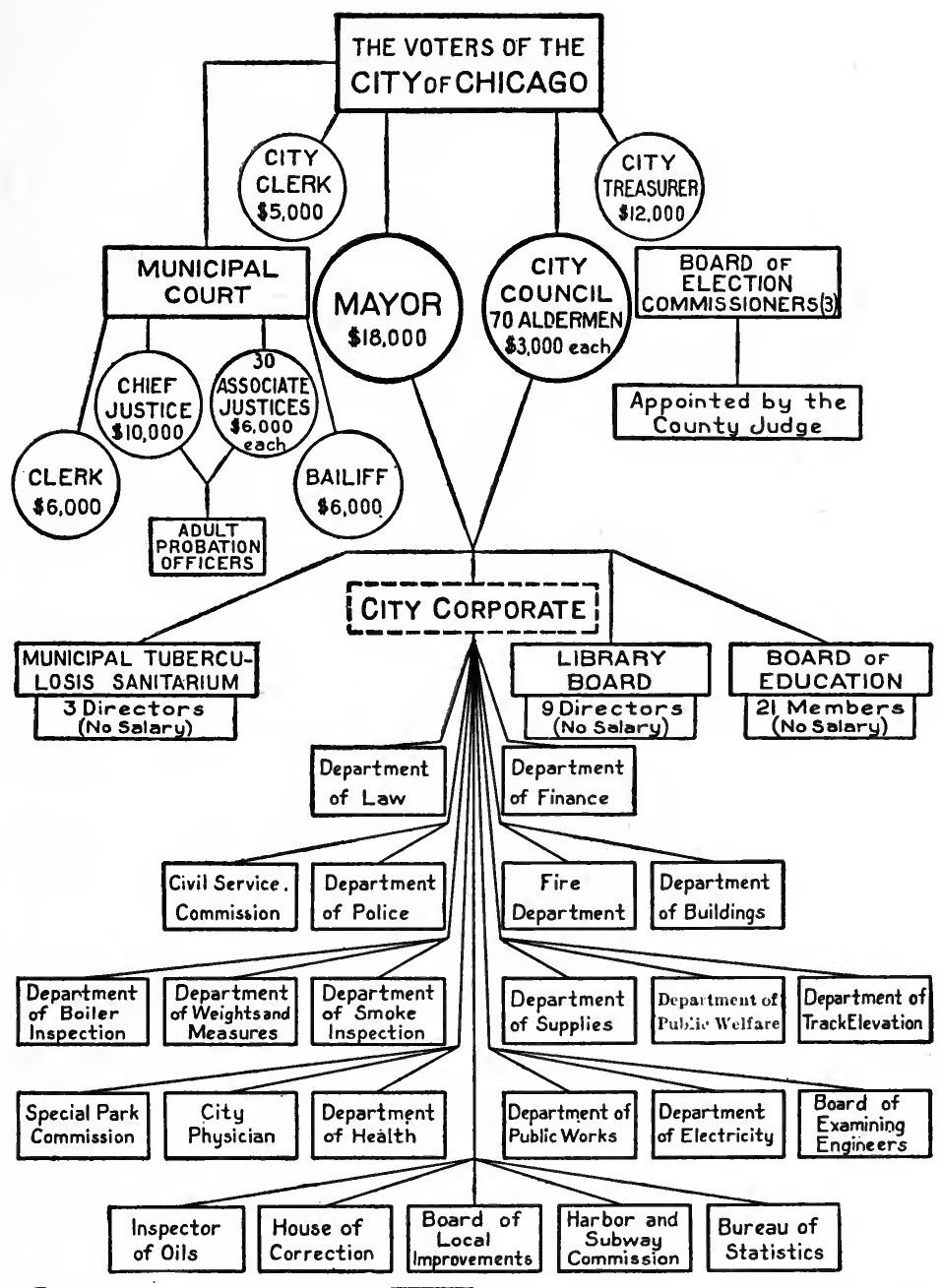

Elective Officials

Departments or Appointive Officials

Prepsred by Chicago Bureau of Public Efficiency, 1913 (10)

Chart of Organization of the government of the City of Chicago showing lines of authority and salary rates for elective officials. 
is their duty to apportion on each piece of property benefited the amount of every special assessment ordered by the council for any local improvement, as a sewer, water main, street or alley paving.

Other Executive Officers. The duties of most of these executive officers are explained by the name of the office, but a few require additional explanation. Comptrol$l e r$ is the financial agent for the city and has general oversight of all persons who handle the cash of the city, or its deeds, contracts, and leases. He is head of the department of finance, and the elected city treasurer and appointed collector are subordinate to him. He is often called " the watch-dog of the city treasury." The City Collector receives special assessments, licenses, and the wheel tax. The Commissioner of Public Works has a great variety of duties and is responsible for more bureaus (subdivisions of departments) than any other city officer. Streets, alleys, sidewalks, their paving, repairing, and cleaning; bridges, viaducts, sewers, and the water system; the engineering bureau; the erection and care of all public buildings belonging to the city; docks, wharves, market places - all these represent part of the services rendered by this huge department. It takes now a small army of 5,000 persons to do this work, and the council appropriated over $\$ 500,000$ in I9I6 for its maintenance. In addition, the commissioner of public works is responsible for the expenditure of other millions in special public improvements (I I) to be constructed, like the proposed boulevard linking the North and South Sides by a double-deck bridge at Pine Street. The Bureau of Streets under the Department of Public Works also has charge of the removal of all waste, refuse and snow from the streets and alleys. This includes the so-called "pure garbage" or 
kitchen waste. In the last three years Chicago has made much progress toward solving her troublesome garbage problem. In proof, note the organization of a Bureau of Waste Disposal under an expert engineer, Col. Henry A. Allen. (See note, Appendix D.)

The House of Correction. The Chicago Bridewell, as the house of correction is commonly called, has two thousand prisoners, most of them serving short sentences, or working out fines imposed for violations of the city ordinances. This large population makes the Bridewell by far the largest prison in Illinois, as there are only about $I, 400$ convicts at Joliet. The Chicago house of correction has a national reputation due to the humane, wise government of its superintendent, John L. Whitman, who has been retained through rival administrations owing to his fine work. The inmates of the John Worthy School (12), an institution for delinquent boys, controlled by Chicago, have been removed to Gage farm, Riverside, where they can have the home life of the cottage and farm and much better chance for reform than under the walls of the Bridewell and in a “ jail school." The John Worthy building is now used for a hospital for inebriates under the management of the superintendent of the house of correction.

Municipal Courts of Chicago. The judicial officers of Chicago are now thirty-one elected municipal court judges, ten of whom are elected in November I9I4. Their term is six years. The municipal court was established by act of Legislature and referendum vote of the people, 1905, and opened December 1906. This court replaces the nineteen notorious justices of the peace appointed by the governor. By amendment to the Municipal Court Act approved I913, the term of part of the municipal court judges will be 
lengthened to allow their election to come in April instead of November. This court tries civil and criminal cases in Chicago where the amount involved is not over one thousand dollars. Imprisonment is in the county jail or house of correction. The court can not commit to the penitentiary. Some of the judges are assigned by the chief justice to certain specialized courts. Three have been established thus far and work well: The courts of Domestic Relations, Morals, and Speeders. There is a chief clerk and a chief bailiff elected for six years and the salary for each office is $\$ 6,000$. The chief justice has $\$ \mathrm{IO}, 000$ salary and each judge, $\$ 6,000$.

Municipal Tuberculosis Sanitarium is an independent taxing body, although the three directors are appointed by the mayor. Under direction of the late Dr. T. B. Sachs, the Sanitarium instructed hundreds of patients in sanitary living, enabling them to resume work. Its work is also preventive through the dispensaries maintained in the more congested districts and through the nurses employed to visit the homes, search out cases of tuberculosis, and get them to the dispensary for treatment if possible; also to teach the home care necessary for cure and to prevent the spread of the "white plague." A municipal sanitarium with eight hundred beds has been constructed at Bowmanville.

The three great public safety departments, health, fire, police; the work of the board of education and the park commissions caring for municipal recreation, all deserve, and will receive, special notice.

Is it wise for Chicago to spend six times as much for protection of property as for protection of life? Notice the table of relative expenditures for these public safety departments (p. 34) and think what it means. 


\section{HEALTH DEPARTMENT OF CHICAGO 1}

"The public health is the foundation on which repose the happiness of the people and the power of a country."- Lord Beaconsfield.

"For most of us, our health is our wealth."

"The health department operates under the police power of the State." 2

"The police power is the right of a community to do whatever is required to protect its health or morals."-Dr. Evans. ${ }^{3}$

Organization. The health department of Chicago is organized under the following bureaus which are directly responsible to the health commissioner appointed by the mayor :

I. Bureau of Medical Inspection has two important divisions:

(A) Contagious Diseases, and (B) Child Hygiene. ${ }^{4}$

A. Division of Contagious Diseases.

Duties:

a. To prevent spread of contagion.

b. To provide school inspection.

B. Division of Child Hygiene.

Duties:

To conduct infant welfare work. Over 100 nurses do the home and school visiting in this division.

1 Courtesy Chicago Woman's City Club. (14)

${ }^{2}$ See Forman: Am. Rep., pp. 313-318; and Adv. Civ., pp. 390-396. ${ }^{3}$ See Report Chicago Dep't Health for 1907-08-09-10.

4 "Little Mothers' Schools" for the practical instruction of young girls in the care of the baby are conducted by the Child Hygiene division of the health department in over thirty of the public schools. Classes are held every week and fifteen hundred girls from twelve to fifteen attend. This is another feature of the Department's campaign to save the babies.

The weekly Bulletin issued by the Chicago Health Department is another important link in this vital chain of disease prevention. (I5) 
2. Laboratory Service.

Duties:

a. To give early, sure diagnosis of contagious diseases through "cultures" taken from throat, nose, or blood of a sick person.

b. Milk and water analysis.

- "Forty per cent. of Chicago's deaths are from preventable diseases."

3. Bureau of Food Inspection.

\section{Duties:}

a. To protect the meat and milk supplies: works with laboratory service.

b. To regulate markets and food supplies. "Death lurks in dirty food."

4. Bureau of Sanitary Inspection.

About 13,000 buildings are erected annually in Chicago. The hundred inspectors have abundance of work to do.

Duties:

a. To regulate housing.

b. To promote cleanliness (see illustration) through inspecting plumbing.

c. To inspect restaurants.

d. Division of Ventilation, established July I, I9I2, looks after ventilation of moving picture theaters, churches, and public halls.

"Bad housing promotes failure, stupidity, crime, disease, and death."

5. Bureau of Vital Statistics.

\section{Duties:}

a. "Points out the path toward greater health for all and records our progress in defeating disease."

"Auditors of the books of Life and Death." 


\section{ALL ABOARD for CLEAN CHICAGO!!}

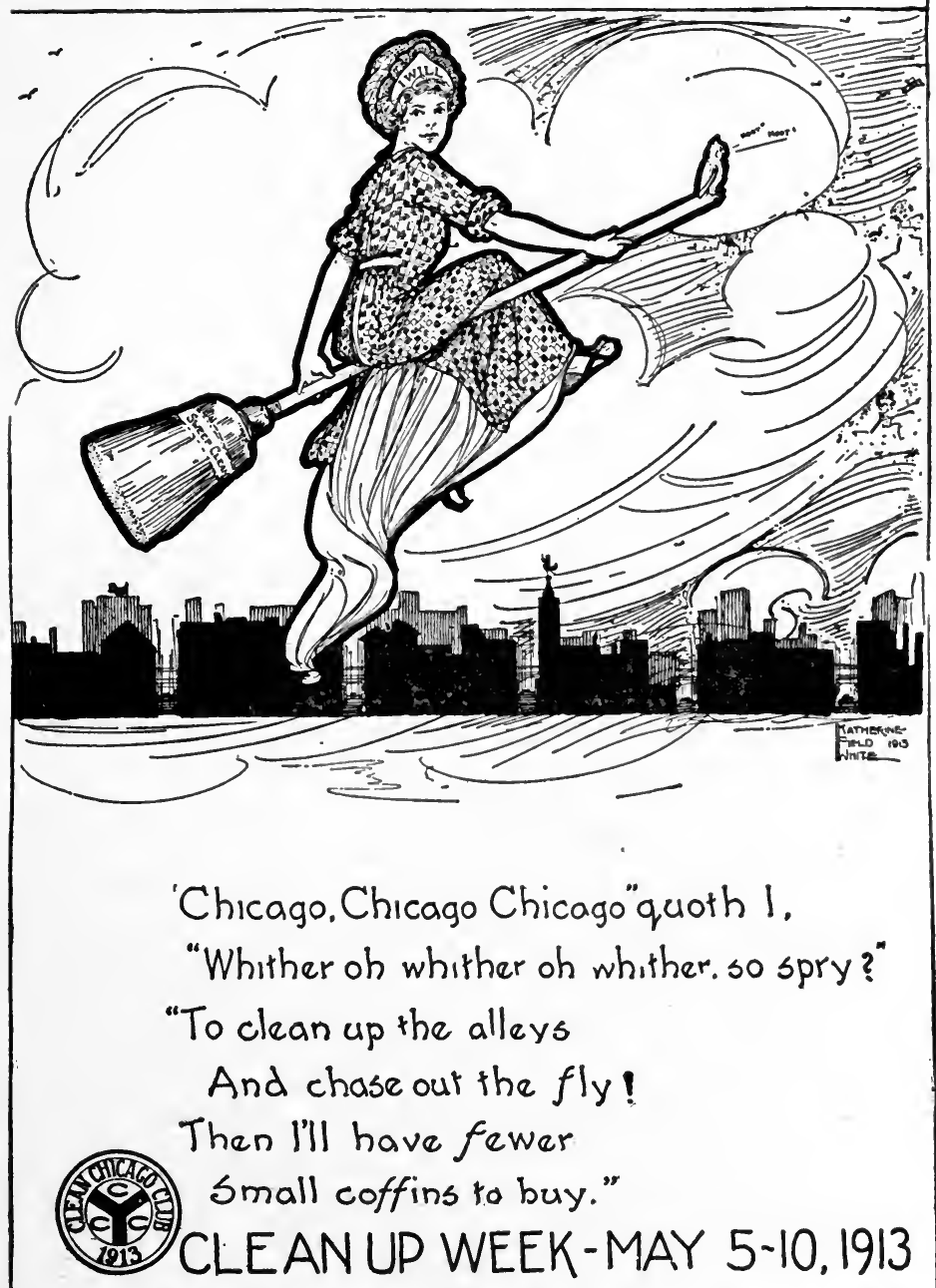

ChicagoHealth Dept Educational Poster N2161 Designed by Dr68Young 
b. Issues burial permits.

Now registers birth certificates. (I6)

A moving picture film entitled "An Error of Omission," to illustrate the inconvenience and loss that may come to any person who can not show a birth certificate, has been prepared and exhibited in many of the theaters. It is hoped to arouse public interest so that every baby will be registered within twenty-four hours of its birth, as is now required by law.

6. Bureau of Hospitals, Baths, and Lodging House. (I 7)

A. Contagious Disease Hospital. [To be opened I9I7.]

Bond issue $\$ 300,000$ voted (I9I2) to erect new hospital.

B. Isolation Hospital for smallpox cases.

C. Free Municipal Lodging House for homeless men.

D. Twenty public baths. Three new ones to be built at cost of $\$ 20,000$ each. Council (January, 1916) appropriated $\$ 37,400$ for running expenses of these bath houses. "Disease means dirt somewhere."

7. Board of Examiners of Plumbers.

Required by State Law.

Independent of the health department is the city physician, appointed by the mayor: salary $\$ 4,000$, with two assistant physicians. The council appropriated $\$ 8,825$ for this department, I9I6. Why are not these doctors under the health commissioner?

How are dead animals removed from streets and alleys?

Notify a policeman or telephone the superintendent of streets in the ward. If not removed within twenty-four hours, call up the health department, because it then becomes a public nuisance and a menace to health. The deadanimal contractor has a contract with the city through the health commissioner by which he must remove such bodies 
free of charge and get his pay from the hides and profit to a rendering plant; but he must be notified only by the proper city department. This is a round-about process, and in the interest of public health, cleanliness, and good municipal housekeeping, ought to be made more simple and direct.

A new contract was made in 1912 by which motor-wagons are to be used for removing dead animals from the streets. Such motor-wagons are already in use for the bodies of small animals, and those for large animals are being built. This insures much quicker, more thorough service for every part of the city. If the citizen could notify directly the contractor instead of being obliged often to call two different city departments, another forward step in municipal sanitation would be gained.

An illustration of the campaign to prevent disease being waged by the department of health follows.

During July and August, I916, the health department exhibited its films, "Summer Babies," and " An Error of Omission," in a large number of moving-pictures theaters in the congested wards of the city. To teach the necessity of pure milk the photo-play, "The Man Who Learned," was also given. About 260,000 people saw these pictures and thus gained a vivid lesson in health preservation. Two new photo-plays, entitled, " Dr. Killjoy Was Right," to illustrate typhoid prevention and show on the screen "the high and mighty tumblers of the germ family" - the typhoid bacilli - and a film, "Life History of a Fly" will soon be exhibited. Nearly a half million persons visit the 600 " movies" in Chicago daily. The health department has been quick to seize such an unrivaled opportunity to secure an audience for a campaign of health education. ( 18 ) 
$\$ 7,324,803 \cdot 90$

$\$ 3,417,659.66$

$\$ 1,490,249.24$

School purposes for education and buildings ......\$23,625,000 Public library, I9I6, for maintenance ......... I,I3I,400 Scaled down under Juul law to $\$ 600,000$ Municipal tuberculosis sanitarium ........... I,040,000

\section{BACK-YARD PROVERBS}

"Have you a 'swell front and a swill back'? Does your landlord, the janitor, do your neighbors, or you yourself, let waste and garbage endanger the neighborhood through carelessness? "- Dr. G. B. Young, ex-Health Commissioner of Chicago. (I9)

Dr. Young has issued some back-yard proverbs to impress his meaning, reading as follows:

"Your back yard reflects your habits of cleanliness.

"What impressions are your neighbors getting from your back yard?

"A dirty neighbor is a menace to neighborhood health.

" 'Personal liberty' must of necessity be subservient to community welfare.

"A dirty neighbor will do more than most anything else to depreciate residence property values. 
"If you value your reputation, your health, or your property keep clean and see that your neighbors keep clean."

The Fresh-Air Crusade. "Four breathing dolls, two mamma dolls and two baby dolls, are booked to cover a good part of the world as missionaries. They are apostles of the fresh-air crusade. It begins to look as though they were destined to do more for the cause of ventilation and fresh air than all the talking that all the doctors of the world have done about it.

"The breathing dolls were invented and set to breathing by Dr. C. St. Clair Drake of the Chicago health department. (20) They are connected by rubber tubes with a little electric pump that pumps incense through their nostrils. You can see the incense rise from them in puffs, for all the world as

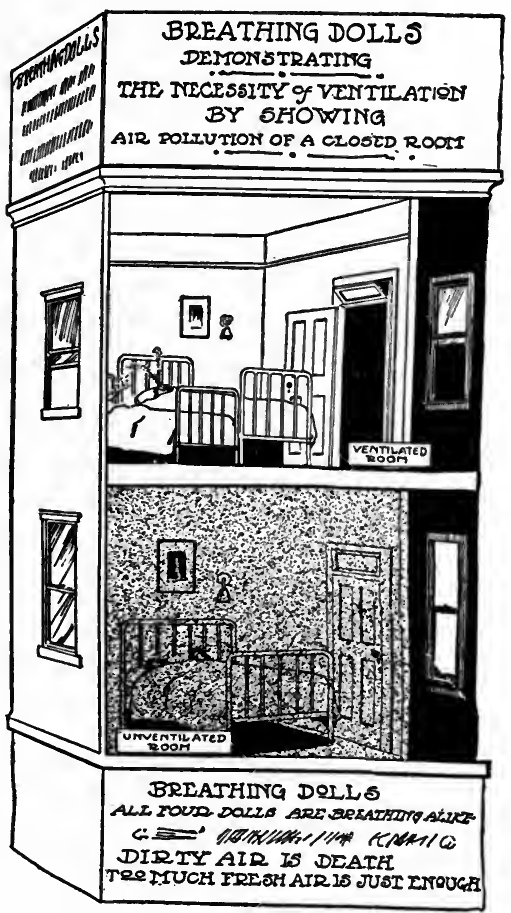
though they were breathing in frosty air. Two of the dolls lie abed in a tiny room with windows and doors wide open. Two lie abed in another tiny room with windows and doors tight shut.

"One side of each of these rooms is a plate of glass. And through these plates of glass whoever looks gets the 
lesson of good ventilation slap in the face. One room is full of smoke and vapor. The glass is clouded with mist. You can hardly see the two dolls that lie abed there, and you can't tell for sure whether they are still breathing or not.

"The other has n't a visible particle of smoke or vapor in it, except for the little puffs of incense that come from the nostrils of the dolls. One room is full of fresh air. The other is full of foul air. One room is well ventilated. The other is n't ventilated at all. 'It is n't likely that any one who once sees this graphic comparison will ever sleep in a closed room again."

Fire Department. In the early 30's, when Chicago was only a village of frame shanties, the trustees expended most of their energies planning to safeguard the village from fire. No person was allowed "to endanger the public safety by pushing a red-hot stove-pipe through a board wall," or " carry open coals of fire through the streets except in a covered fire-proof vessel." All citizens were required to keep a fire-bucket in the house and on an alarm of fire, hurry to the spot equipped with said bucket ready for immediate use. The village grew so fast a hook and ladder company was formed in 1835 and the first fire-engine was purchased for $\$ 894$, a wonderful engine for that day. Contrast the modern automobile fire-engine costing $\$ 9,000$ now used by the city.

Chicago now values her fire-fighting equipment at more than \$3,000,000. At the head of the force, two thousand strong, is the fire marshal, appointed by the mayor and paid $\$ 8,000$ for his hazardous work. His position is no sinecure; he actually leads his men at many of the fires and must be an experienced firefighter to hold his place. He has 
six assistant marshals, one of whom has charge of fireprevention work.

The entire city is divided into twenty fire districts, with a chief and battalion of firemen in each district. The organization and discipline are military in effect, and Chicago has the reputation of possessing one of the best organized and bravest bodies of firemen in the country.

The equipment includes nearly one thousand horses, six fireboats, steam and chemical engines, automobile-engines and trucks, hook and ladder companies, and old-fashioned hose carts. There is great need of a new high-pressure water system to protect Chicago's sky-scrapers.

The anniversary of the great Chicago fire, October 9, 19I3, was celebrated throughout the State by the inauguration of a fire-prevention day. Governor Dunne by proclamation recommended its observance. Property-owners were urged to clean up their property so as to lessen the hazard. Fire drills were held in many schools and shops, and an effort made to have rubbish disposed of so that it would not increase the fire risk.

Governor Dunne in his proclamation said: "Statistics show fire waste is increasing annually in the State of Illinois, and last year it averaged $\$ 1,000,000$ a month. Besides this, nearly four hundred people in this State lost their lives through the agency of fires. No nation or State can long endure the waste and drain upon its resources due to fire, and the fact that so many of them are largely preventable is a reproach to our people and needs immediate attention and remedy." (2I)

What can we do as public-spirited citizens to decrease this appalling waste from fires? Here is another reason for frequent "municipal house cleaning days." 


\section{POLICE DEPARTMENT OF CHICAGO}

Under the ordinance, passed January 27, I9I3, for the reorganization of the police department of Chicago, the general superintendent, appointed by the mayor, with consent of council, at a salary of $\$ 8,000$, stands at the head. "It shall be the duty of said general superintendent of police to preserve the peace and secure good order and cleanliness within the city of Chicago, and to that end he shall enforce all laws and city ordinances and the orders of the city council and the mayor."

It takes an army nearly five thousand strong to guard the lives and property of the city, and it costs Chicago taxpayers for this service over $\$ 7,325,000$ this year.

The active force of men is now directed by the first deputy superintendent under the new semi-military organization. The second deputy superintendent must not be a member of the police force, but is of equal rank and salary with the first deputy. Both are under civil-service rules. The second deputy has charge of all departmental property, records, inspections, and drills. He has charge of the moving-picture bureau, the lost and found department, and the supervision of moral conditions in the city. Should you have any complaint to make about the conduct of the policeman near your home, report to the second deputy superintendent. He also provides a system of credit and demerit marks to be charged up to the men by their commanding officers during drills, both mounted and unmounted, and these marks have a decided effect on their records toward retention in the service and for promotion. This is one way to secure good discipline among the force.

A brief account of the various bureaus under which the, 
department is organized will best show the great number of services the force renders.

I. Two motor-boats rescue drowning persons, recover bodies and property from the water.

2. Patrolmen assigned to the forty-five police precincts into which the city is divided. These men cover the I99 square miles of the city's area.

3. Traffic squad. The pick of the force are assigned to guard the street-crossings in the loop and they prevent many accidents every day.

4. Mounted police - about I75.

5. Ambulance and patrol-wagon service. There are police ambulances for accident cases in eight wards; many automobile-patrols and automobile-ambulances are now in use, a modern feature, increasing many fold the effectiveness of this service.

6. Motorcycle squad for rapid service: to control speeding on the city highways and for special strike duty. The tracking of stolen automobiles is another useful service of this swiftly moving squad.

7. Vehicle Bureau. Issues licenses to peddlers, public automobiles, hack-drivers, garages, stables, and all motorcycles and express-wagons.

8. Bureau of Vagrancy. Arrests, brings to punishment, or deports all suspicious persons and loiterers who seem to have no regular business. The article, "The Forgotten Army," by H. M. Hyde, Chicago Tribune, September 4, I9I 3, gives a different view of Chicago's army of vagrants. The article is well worth reading.

9. The Dog-Pound Master imprisons stray or vicious dogs, looks after the dog licenses, and kills dangerous animals. 
IO. Detective Bureau identifies and keeps track of criminals by aid of photographs (the " rogue's gallery"), fingerprints, etc.

I I. Moving-picture Bureau has the censorship of films, postal and picture cards. This bureau suppresses hundreds of indecent films and postcards every year. It also inspects theaters and arcades. The movies furnish the only amusement within reach of a large part of the population of Chicago. Over a half million men, women, and children visit these shows every day. Of this number over I 50,000 are children under fifteen years old. A strict censorship of the films in Chicago is very necessary. ${ }^{5}$

I2. Ten policewomen were appointed by the mayor July, I9I3, and placed on patrol duty in the dance halls, at bathing beaches, and moving-picture theaters. ${ }^{5 a}$ They report to the first deputy and are especially charged to look after unprotected women, girls, and children. In each of the ten police-stations where women arrested are taken, there is a police-matron to have charge of such women. There are now about seventy-five women officially connected with the department.

I3. Custodian of Lost, Stolen, and Seized Property. About 5,000 packages of money, jewelry, clothing, revolvers, bicycles, slot machines, were received by the custodian during I9I5. More than \$ 5,000 in cash was held in trust by him. Slot machines and all gambling outfits must be destroyed immediately. Revolvers and all dangerous weapons taken must be dumped in the lake five miles from shore. One of the police motor-boats is used to do this. All unclaimed property is sold at public auction and the proceeds turned into the police pension fund. It is well for

${ }^{5}$ See Report Gen. Supt. of Police I912, pp. 5 and Ior.

5a There are now thirty policewomen. 
citizens to understand what becomes of lost and stolen property taken up by the policemen and that they must go to the custodian's office in the city hall to recover such property.

Public Safety. Stop! Look! Listen! ${ }^{6}$ How can each of us help to reduce the large and growing number of street accidents? Every time we dart across the street before the traffic policeman's signal ; cross the street, or even a country road, without looking in both directions for autos and teams; attempt to drive over a railroad crossing after the warring signal has rung, or the flagman has given notice the train is coming, we wilfully, to save two minutes' time, run the risk of death, or even worse, being crippled for life, by our lawless act.

Let us call things by their right names. We are lawbreakers when we run these risks, for no one has any moral right to endanger his life and limbs in such a reckless fashion. If private citizens would take half the pains to guard their own lives that the city police department through its fine traffic squad, and the railroad and street-car corporations, take to protect and safeguard us, the death harvest from preventable street accidents would be diminished fifty per cent.

Teamsters, truck-drivers, autoists, are finable if they disobey the whistle of the traffic policeman. There should be a similar ordinance giving the right to arrest and fine any pedestrian who likewise disobeys the traffic signal. Until the council puts such an ordinance into the municipal code, all citizens can help reduce the dangers from Chicago's congested streets many-fold if they will simply render implicit

${ }^{6}$ See article by F. V. Whiting, by this title "Outlook," August 23, 1913. Also Chicago City Manual for 1912, pp. I67-I7I; Mayor's letter on "The Automobile and Motorcycle Peril." 
obedience to the traffic signal - one whistle allowing all vehicles to move north and south; two whistles, east and west. The pedestrian's opportunity is when the city guardian of public safety has halted one of the moving lines.

Chicago Railways Company has a Public Safety Bureau and exhibits moving pictures to illustrate its safety directions. The company will gladly loan its films to any organization or school desiring to teach its useful public-safety measures. A Public-Safety Commission of twenty-five citizens was organized (September, I9I3) by the coroner of Cook County, to investigate the great number of deaths in the county through accidents and to suggest ways and means to enlist the public in a campaign to sa feguard human life on streets and highways.

\section{SCHOOL SYSTEM OF CHICAGO.}

The board of education, of twenty-one members, five of whom are now women, are appointed by the mayor, with the consent of the council, and have entire control of Chicago's great public-school system, with three exceptions. The council must concur whenever bonds are issued, sites purchased, or school buildings are erected. The board appoints the general superintendent, at present John D. Shoop who succeeded Mrs. Ella Flagg Young, an educator, retired since 19I5, whose work for the Chicago schools was remarkable. In the words of Mrs. Young, the aim of the school system is: "To invigorate and strengthen the children for their future as citizens of this republic."

The first school building owned by Chicago was built in I 844 on the present site of the Tribune Building, Madiison and Dearborn Streets. This' block is still school land.

The following quotation from Beard's American City 
Government, p. 136, is a good illustration of the "unearned increment" in land values in Chicago and what income the city schools might have had: "In I8I8- when Illinois became a State - the United States government gave the square mile between State, Madison, Halsted, and Twelfth Streets, to the State of Illinois, to be held in trust for the support of the public schools and the education of the children of Chicago. Except for one block, between Madison, Dearborn, State, and Monroe Streets, nearly all this square mile was sold about seventy years ago, for less than $\$ 40,000$. Within fifteen years after it was sold this square mile was worth $\$ 6,000,000$. To-day its value is hundreds of millions of dollars - without improvements. The rent for this square mile of land would be sufficient to support for all time the entire school systems of the State of Illinois without an additional dollar of taxation." This statement was made in 1909 by three former members of the Chicago school-board. The "unearned increment" is the great increase in the value of land due entirely to increase in population and in no wise to any effort or labor on the part of the owner.

“If Chicago's standing army of 400,000 school children were formed in military order, eight abreast, this army would make a line fifty-two miles long - longer than any street in the city." To care for this army, the city maintains three hundred public and high schools with seven thousand teachers at an expenditure for 1916 of $\$ 16,500$,ooo for running expenses and $\$ 6,000,000$ for new school buildings - a grand total of $\$ 22,500,000$ for public education. $^{7}$

${ }^{7}$ Much of this material was prepared in the form of charts by the Chicago Woman's City Club, through whose courtesy it is used here. 
What has Chicago to offer in return for this vast sum, which forms one-third of the taxes collected for all purposes? A child may enter a kindergarten at five and pass through the eight grades, then four years in high school, and two years at the city normal (22) - should the boy or girl desire to teach,- eleven years' training at public expense. A child may have physical, technical, manual, and domestic-science training in addition to the regular mental work, with music, drawing, painting, and all commercial branches thrown in. For the workers who are ambitious for an education, the city provides evening schools with a regularly paid corps of instructors. October, I9I6, there was a small army of 30,000 , many over twenty-one, enrolled in these "after-supper" classes.

Notice this list of special classes maintained for the deaf, blind, crippled, and subnormal children; open-air and lowtemperature schools for tuberculous children; a parental school for truants at Bowmanville, caring for three hundred and twenty-five boys under fourteen; and a school at the Juvenile Detention Home for delinquents; apprentice, vocational, agricultural, and continuation schools. In many of the crowded districts the schoolhouse is used as a social center for the neighborhood and provides a free hall for all kinds of public meetings, clubs, dances, and classes of every kind, all under suitable supervision, often a paid social director. The people of Chicago are beginning to use their tremendous investment in school lands and buildings seven days a week and twelve months a year instead of letting it stand idle one-third of the time.

What of the child who must leave school and go to work? The board of education holds out a helping hand to aid him in finding a suitable job through a new bureau of vo- 
cational supervision. This bureau keeps a list of employers of child labor, investigates the positions, consults teachers, employers, parents, and the child, and then tries to get the young worker into a suitable position for which he is naturally fitted.

\section{CHICAGO PUBLIC LIBRARY}

Chicago owes her public library to the efforts of an Englishman, Thomas Hughes, who secured a donation of seven thousand volumes in England immediately after the great fire of $187 \mathrm{I}$ and persuaded even Queen Victoria to contribute some of the books. The first volume of this collection, bearing the Queen's autograph, is still exhibited in the library if any interested visitor requests a view of the book.

The present beautiful building houses over 400,000 volumes and serves more than 100,000 regular patrons holding readers' cards. In the reading, circulation, reference, public documents, civics, art, and children's rooms, the general and special needs of readers are met. A recent innovation is a "study room for women," on the fourth floor, to serve the needs of club women in preparing club programs and for the study of topics included in all governmental subjects of interest to the new woman voter who desires to use her ballot intelligently.

The present librarian (23) won his position through competitive examination - a pioneer experiment in civil-service examinations for such difficult and important positions. It proved a decided success in securing an efficient, progressive librarian.

A dozen branch reading-rooms, many in schools and field houses in the parks, and several circulation centers are also 
maintained. Many delivery-stations for the convenience of readers in distant parts of the city are maintained.

The library is governed by a board of nine directors appointed by the mayor with the consent of the council, for three years, and they serve without pay. The library is supported by a special tax of one mill which is levied on all taxable property in the city, but this is scaled down under the Juul law.

\section{MUNICIPAL RECREATION}

\section{REFERENCES :}

I. Annual Report: Special Park Commission, Chicago, I9I5. (This shows what can be done with a small sum of money wisely used.)

2. The Park Governments of Chicago, Chicago Bureau of Public Efficiency, December, I9II. (Following facts are largely based on this admirable report. All the reports of the Bureau of Public Efficiency are of exceeding value and interest. They are supplied without charge to any one who desires them.) Address the director, Harris S. Keeler, 315 Plymouth Court, Chicago.

3. Map of the park districts of Chicago. (24)

"The Chicago park situation is unparalleled in any city of this country." This bad condition is due to the large number of independent park districts. Chicago is famous the world over for its parks, playgrounds, and boulevards; but the city sadly needs consolidation of park management under the city government. There are sixteen separate park governments within the city of Chicago, not counting the special park commission, an arm of the city government. Fifteen of these governments are independent taxing bodies, the Lincoln Park Commission having no separate taxing power. Existing park boards now spend approximately six million dollars annually. Do the people of Chicago re- 


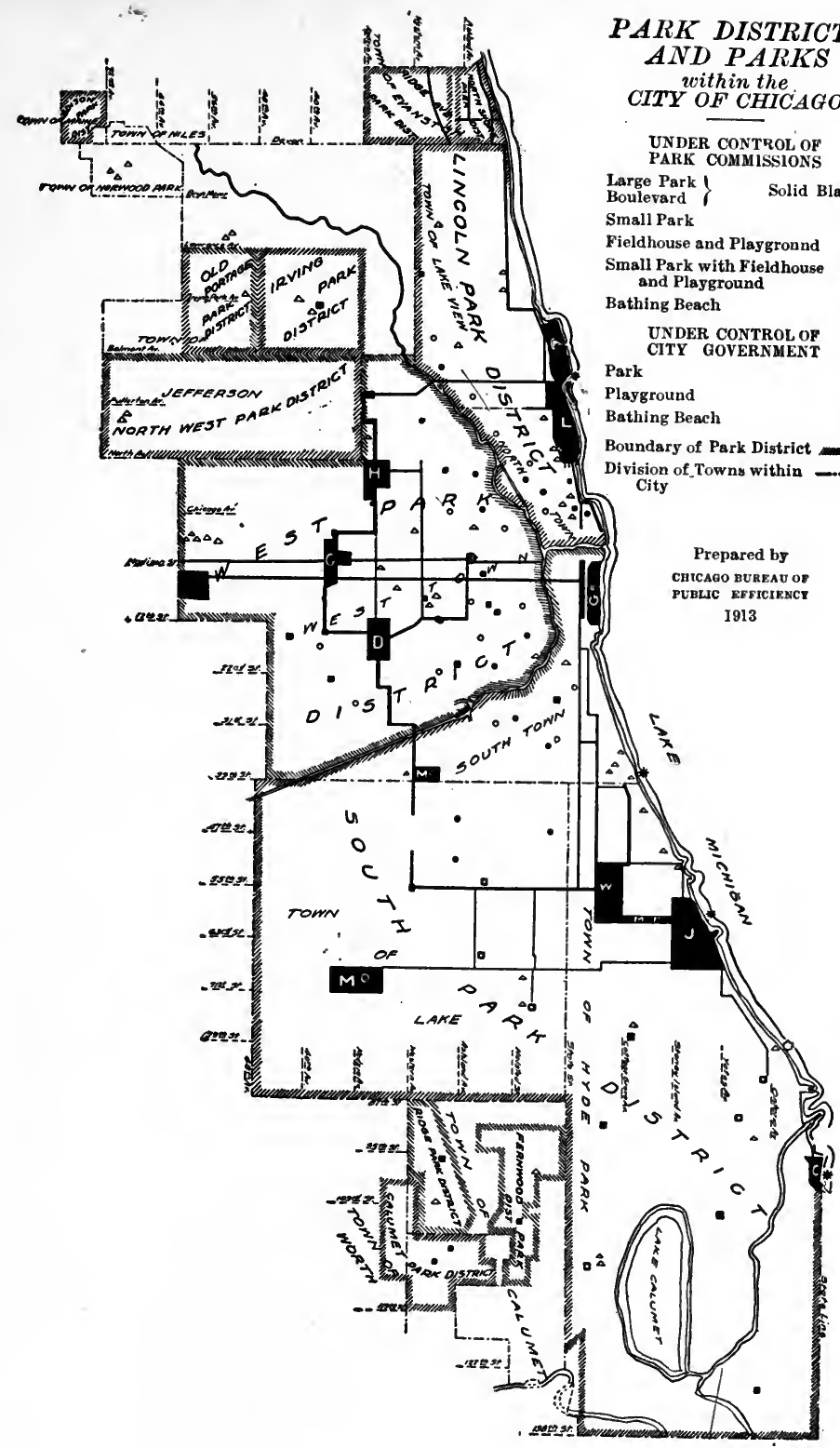


ceive dollar for dollar in value for this large expenditure?

Moreover there is a general statute, applying to territory not within any existing park district, under which additional park districts may be established by petition signed by one hundred voters, to the county judge, and a special election to approve such petition for a park district. Five commissioners are elected to manage the new district. These commissioners have power to levy a special park tax. The commissioners serve without pay, and may issue bonds if permitted by the voters. This law applies to the entire State and under its authority thousands of park districts have been created.

The park districts of Chicago are very unequally divided among the three sides of the city. The entire area is now over 3,500 acres ; but it is not distributed according to population and the great needs of the people in the congested wards of the West and Northwest Sides.

The park governments (25) as now organized can not easily be controlled by the people of Chicago. The West and Lincoln Park Boards are appointed by the governor of Illinois and the South Park Board by the circuit judges of Cook County. The park employees since I9I I have been under the civil-service rules of the State. Consolidation of the several park governments with the city government would centralize control and responsibility and make the government of the parks more democratic. The saving thus effected is estimated at a half a million of dollars a year. That sum of money would go a great way in extending Chicago's system of small parks and playgrounds. The special park commission under the city government does wonders with its small appropriation from the city council. 
The South Park Board has the great advantage of the immensely valuable property in the loop to tax and therefore has more money than it can spend. This naturally leads to extravagance and waste, while the crowded West Side, with its congested foreign population, and dire need of public recreation parks, swimming pools, and field houses, is too poor to provide all these facilities unaided. The only sensible method is to fit expenditure to needs and spend the South Side surplus on West Side necessities.

Chicago's Problems. One of Chicago's most difficult problems is the large percentage of foreign-born whites in the city - now 35.7 per cent. If to these foreign-born persons are added those of foreign or mixed parentage, Chicago's percentage leaps up to 77.5. Chicago ranks third among the cities of the United States in its population, foreign born and of foreign-born parentage. New York heads the list with 78.6 per cent.; Milwaukee has exactly the same percentage - 78.6 per cent.; Chicago is third, with 77.5 per cent. (26)

In common with all large American cities, Chicago shares the problems created by the presence of such numbers of the foreign born, alien to our language and our ways, yet eager to learn both and share in our opportunities for work and the chance to make good in business and industry. We must never forget our heavy debt to the strong muscles and willing hands of these strangers in our midst. They build and elevate our railroads, dig our drainage canals and sewers; man our factories, build our sky-scrapers and make possible all our great manufacturing industries. They give us the best they have, their strength and health. What return do we make for this necessary service? Too often the slum district is our answer. 
Chicago is face to face with large problems of municipal improvement that must be solved soon, or the city cannot go forward. A sanitary, economical, modern disposal of garbage and all kinds of city waste heads the list, a system big enough to care for every block in the city (27); rapid, safe, cheap transportation that will distribute the working population away from the congested centers into suburbs where there is land suitable for homes; the best way to "burn our own smoke" and clear the atmosphere; the redemption of the lake front; consolidation of twenty-two separate governments within Chicago: a suitable harborthese seem to be the most pressing of Chicago's problems.

John Fiske was right when he wrote:" "The modern city has come to be a huge corporation for carrying on a huge business with many branches." It is coming to be more human than a corporation and to mean a business proposition plus social service.

\section{SANITARY DISTRICT}

Of the sanitary commissioners and sanitary district trustees, throughout the State, the most powerful and the best paid are those of the sanitary district of Chicago. Study the map of the sanitary district, p. 5I. The sanitary district of Chicago is a municipal corporation created by the act of 1889 to provide a drainage system for the "preservation of the public health" by purifying the water supply. This is to be accomplished finally by turning all the sewage in the sanitary district into the drainage canal and away from Lake Michigan.

The excavated portion of the sanitary canal begins at Robey Street, Chicago, and runs about thirty miles to the controlling works at Lockport. Fifteen miles of this main 


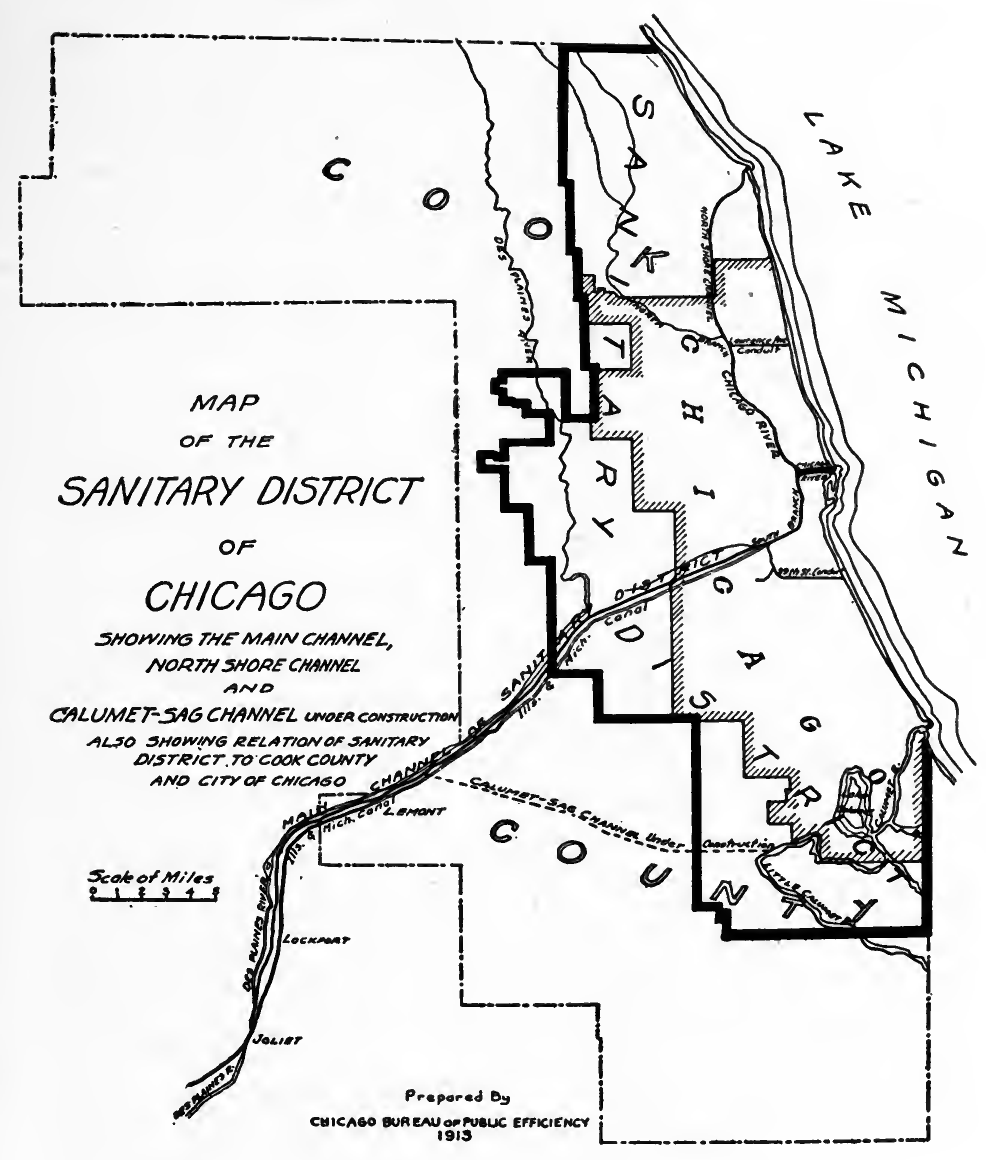


channel is cut through solid rock. It cuts through the watershed, once a glacial moraine, at Summit, Illinois, and reverts to preglacial conditions by reversing the current in the Chicago river and causing that river to flow west and south instead of into the lake.

The entire canal is one of the most remarkable in the world owing to difficulties surmounted in its construction and to its purpose: The canal was opened by admitting the required amount of water from Lake Michigan in January 1900.

There are nine trustees elected for six years, in the November elections, only three being chosen at once. The original act has been amended several times to increase the territory included in the district and the powers of the sanitary trustees by allowing them to develop and sell the electric power created by the canal. The sanitary board sells the electricity developed at Lockport, and the cities of Joliet, Lockport, and part of Chicago are lighted from this current: also the Chicago City Hall; Lincoln Park, West and South Side systems (in part), and the County Building. It costs about fifteen cents an hour to light brilliantly the council chamber of the Chicago City Hall from this municipally generated electric current - a striking illustration of the difference in cost of a commodity manufactured by a public instead of a private corporation.

The sanitary trustees have very large powers of taxation and bond issue. The employees of the district are not under any civil-service law, and appointments are largely made for political instead of merit reasons. The man who controls the vote gets the " job" every time! This is a serious defect in the law because of the millions of dollars expended by the sanitary board. The drainage canal has 
cost the people over eighty-five millions already, and contracts are pending in the construction of the Sag-Calumet branch canal that call for many millions more. Such huge expenditures demand honest, efficient work and strict account of every dollar spent if the tax-payers get a just return for their money. The salary of the trustees is large - \$5,000 annually - and the president of the board has $\$ 7,500$. These increased salaries have been in force since July I, I9I I. (Rev. Stat., I912, ch. 24, sec. 346.) This is another reason the work of the board should be carefully watched and only men of the highest character, who will serve the public faithfully, be elected as trustees. (28)

28 refers to non-partizan organization of Council Committees. See pp. 224-225, Appendix D. 


\section{CHAPTER III}

\section{TOWNS AND TOWNSHIPS IN ILLINOIS}

\section{REFERENCES :}

I. Forman: Advanced Civics, ch. xxvii.

(Hist. town and township government in general.)

2. Forman: American Republic, chs. xxiii, xxiv. (In general.)

3. J. A. Fairlie: Town and County Government in Illinois; Report Joint-Leg. Com., 47th Gen. Ass'y, I9I2, Vol II.

4. M. H. Newell: Township Government in Illinois, 1904. Ill. Hist. Pubs., No. 9, pp. 467-504.

5. Revised Statutes, ch. I39.

I. Meaning of Terms. There is great confusion in the use of the terms, toron, township, civil and congressional townships, and incorporated town throughout the State. The following definitions are based on the Revised Statutes and decisions of the Illinois Supreme Court:

The terms tozm, township, and incorporated town are used in various ways to describe (I) geographical and (2) civil or governmental divisions of the county or State, as follows:

"I. The term township, or its abbreviation town, is used to describe a geographical division of land, approximately six miles square. This is also known as a congressional township, because its boundaries were determined by the United States governmental survey under an act of Congress.

" 2. The term township, or its abbreviation town, is also used to designate a civil division of the county. This civil township, or town, is an involuntary governmental agency; that is, it is imposed upon the people living within the territory which it em- 
braces by a vote of the electors of the entire county, rather than by a vote of the electors who live within its boundaries.

" 3 . The term tozm, or incorporated town, as it is more frequently used, denotes a municipal corporation which in all essential respects is identical with the municipal corporation known as a village. ${ }^{1}$ The incorporated town or village differs from the civil town or township in that it is a voluntary municipal corporation organized by the voters living within the territory included in the town or village, whereas the simple town or township is an involuntary governmental agency, as explained above."

\section{How Towns Are Formed. Any county in Illi-} nois may be divided into towns whenever a majority of the voters at any general election approve the proposition. In that case it is the duty of the county board to appoint three commissioners to make the division. The commissioners must make the towns coincide with congressional townships if possible and must select names for them; but no two towns in the State may have the same name. ${ }^{2}$

"In I9Io there were I430 civil townships, or tozuns, in the eighty-five counties of Illinois under township organization. Most of them are rural communities with a population from I,000 to 2,000. But, except in Chicago, where the townships have been practically abolished since 1903, the Illinois townships include cities and villages within their geographical limits; so there are a number of townships of from 10,000 to 60,000 population. The township of Joliet, for instance, contains 16,000 inhabitants out-

1 "This does not mean that the powers of a village organized under the Cities and Villages Act may be exactly the same as the powers of an incorporated town, because the incorporated town, in most cases, was incorporated under a special act of the Legislature passed prior to the constitution of 1870 and under and by virtue of which the town still exercises such power as it has. A special charter like this might confer other or different powers than those conferred upon a village organized under the Cities and Villages Act."

2 Rev. Stat., ch. I39, sec. I-7. 
side of the city of Joliet. There are also eight cities in Illinois coextensive with townships - East St. Louis, Springfield (Capitol Tw'p.), Evanston ("Town of the City of Evanston"), (I) Rock Island, Moline, Macomb, Berwyn, and Belleville. The village of Oak Park is also coextensive with the township of the same name."

The city of Cairo is coextensive with the election precinct of the same name. Cairo's county, Alexander, is a "non-township" county. These facts illustrate the truth of Dr. Fairlie's conclusion that the "system of local government in Illinois as a whole is more complicated and confusing than in any other State." 3

III. The Town Legislature. The General Assembly of the State and the county board are representative bodies elected by the voters. On the other hand, in the town the law-making body is the voters themselves assembled in a town- or mass-meeting. This means a pure democracy and is the only instance of such kind of government in Illinois. The annual town-meeting is held the first Tuesday in April. This is the months for all regular local elections in Illinois except that for the county officers, which occurs in November at the same time as the election for State officers, congressmen, United States senators, ${ }^{4}$ and Presidential electors.

Towns lying wholly within the limits of a city elect town officers on the same day as the city elections, the third Tuesday in April, except in Chicago, Evanston, and several

3 Town and County Government in Illinois, by John A. Fairlie, in Report of Joint-Legislative Com., 47th General Assembly, 19I2, Vol. II. Also see article, same title and author, in Annals Am. Acad., May I9I3, pp. I-4, 9-12. Dr. Fairlie's reports are classics on the very difficult subject of local government in Illinois.

${ }^{4}$ Seventeenth Amendment, Constitution U. S., I9I3. Popular election U. S. senators. 
other cities where the old towns are practically abolished and the work of the town officers performed by the city officials. The business of the town-meeting, presided over by a chairman called a moderator, is now very slight: to elect town officers, hear reports, provide for keeping the roads clear of stray cattle, and a few other duties. The town government is for rural communities, and is very much out of date for cities and large villages. In New England and in the rural counties of Illinois under township organization, the town-meeting is still "a school for citizenship."

IV. Town Executive Officers. The town officers are a supervisor (with assistant supervisors in the more populous towns), town clerk, assessor, collector, now elected for two-year terms $;^{5}$ three commissioners of highways, elected for three years, one retiring each year; ${ }^{6}$ justices of the peace and constables, from two to five according to population, elected every four years. These town officers are paid by the day for actual services, or by fee. It would be much better if they were paid annual salaries and required to render strict account of all fees received. There is a town board of health, consisting of the supervisor, assessor, and town clerk. Also a board of town auditors, made up of the supervisor, clerk, and justices of the peace, that examines all accounts of the town offices.

SUPERVISOR. In counties under township organization, except Cook County, the supervisor acts in two capacities: as chief executive for the town and as a member of the county board. As a town officer he handles all town funds

${ }^{5}$ Since April, 19ro. Rev. Stat., ch. 139, sec. 154 .

${ }^{6}$ May elect only one, if voters of township choose. 
except school money ${ }^{7}$ is ex-officio overseer of the poor, and provides temporary relief for persons in need, or arranges for their care in the county infirmary (poor house). In towns of more than 4,00o population there may be a special poor master appointed by the county board. In this case there is little left for the supervisor to do, because the town tax levy is only a few hundred dollars. The average for I9I2, outside of Cook County, was only \$6 I5.

Town CLERK keeps the records of town-meetings and all books and papers for the town; certifies to the county clerk the amount of taxes required for town purposes and acts as clerk for the highway commissioners.

AsSESSOR places a value on all taxable real estate within the town and distributes and receives all personal property schedules. $^{8}$ The election of town assessors frequently illustrates the "survival of the unfit," because they get reelection on the promise to assess property in the town low, regardless of needs.

Collector receives all general taxes in the township and pays them over to the proper officers, retaining his percentage for collection. ${ }^{9}$

Highway Commissioners (one or three, as the township decides at an election), levy the road and bridge tax. This road tax must now (I9I3) be paid in money. A poll (head) tax, from one to two dollars, may be levied for road or bridge building. ${ }^{10}$ This is the only poll tax ever levied in Illinois. (See Chapter IV, The County.)

7 Will act as town treasurer after April I9I4, and custodian of the road and bridge money. Session Laws, I9I3.

${ }^{8}$ See ch. v, The Public Pocketbook, p. 91

${ }^{9}$ See ch. v, The Public Pocketbook, p. 95.

10 State Aid Good Roads Law, in force, July I, I9I3. 
Justices of the Peace ${ }^{11}$ and Constables are the $j u d i$ cial officers of the town. There must be at least two in each township, so that a case may be changed from one justice's court to the other if any partiality is shown either party in the suit. This is called "change of venue." The number of justices and constables can not exceed five. Although elected in the township, their jurisdiction extends over the entire county.

The jurisdiction of a justice of the peace is limited to petty, civil and criminal cases involving not more than $\$ 200$, or where the punishment is by fine only, not over $\$ 200$ and costs. They may try violations of the dram-shop law, cases of assault, or assault and battery; but they may $e x-$ amine any case and bind the offender over to await the action of the grand jury. This will hold him in the county jail until his trial unless he can secure bail.

Justices also have the right to perform marriage ceremonies. They may put any violent or disorderly person under a bond to keep the peace. Justices are paid by fees and this is often a source of much injustice and petty graft. Our petty courts would be much improved if justices of the peace and constables were paid fixed salaries and the fees collected went into the town or the county treasury.

The orders of the justice of the peace are enforced by the constable. It is his duty also to keep peace in the town and arrest offenders. In counties without tow:ship organization, the justices and constables are chosen in each elec-

11 Ridgeville Township had the distinction of having the first woman as justice of the peace in Illinois, Mrs. Catherine Waugh McCulloch, of Evanston. She was elected April 1907, and reëlected April 1909. She held an office for which she could not vote herself, a curious anomaly. Two other women have been elected justices of the peace in Illinois since Mrs. McCulloch's election, but she was the pioneer. 
tion district into which such counties are divided by the county board.

Town officers do their most important work as agents of the State and county governments, especially in the assessment and collection of taxes.

"Non-Township" Counties. There are seventeen "non-township" counties in Illinois. These seventeen counties have assessors, collectors, highway commissioners, justices of the peace, and constables elected in " road districts" and "election precincts" into which these counties are divided by the county board. They do not have supervisors or town clerks because the duties of these officers are performed by the three county commissioners and the county clerk.

The following comparison of the peace officers in cities and towns is of value:

\section{DIFFERENCES, POLICEMAN AND CONSTABLE}

\section{Policeman}

I. Has regular hours, a " beat," or place to patrol, and a uniform.

2. Can serve warrants only.

3. May arrest on sight.

4. Has relation to criminal actions only.

5. Executes orders of a mayor.

6. Jurisdiction is the city.

7. Is appointed by chief of police and the mayor; usually under civil-service rules.

8. Term is good behavior.
Constable

Has none of these.

Can serve all writs.

Must have a warrant.

Has relations to both criminal and civil actions.

Executes orders of a judicial officer as police magistrate, justice of the peace, or judge. Jurisdiction is the county.

Is elected in each township; number depends on population and cannot in Illinois be more than five.

Term is four years. 


\section{TOWNS AND TOWNSHIPS IN ILLINOIS 6r}

\section{Township Survey Systems. The old colonial}

system of surveying land was very crude and unsatisfactory. The old boundaries were trees, even stumps, a "quart of charcoal buried under a certain tree," and similar removable marks. Confusion of ownership resulted, and many lawsuits over the title to land. The rectangular system of surveys now in use throughout the West was adopted by Congress ( 1785 ) and is called the "simplest of all known modes of survey." Thomas Jefferson was chairman of the committee in Congress that proposed this system and therefore the plan is often attributed to him; but the real originator was Thomas Hutchins, the first surveyor-general of the United States. (Currey, Hist. Chicago, Vol. I.)

i. Congressional Townships. Nearly all public land in the West is divided into townships of six miles square "as near as may be," called congressional townships. Some prominent geographical feature, as the mouth of a river, is taken for a starting point and through this is drawn a meridian line running north and south, known as the principal meridian. Through this line at some selected point and at right angles to it is run another line called the base line. Starting at the intersection of these two lines the surveyor measures off distances of six miles on both, and through these points runs new intersecting lines. The squares of land thus formed contain 36 square miles, "or thereabouts," and are the congressional townships, bounded by the lines running north and south, east and west.

2. Sections. Each township is subdivided by a further series of similar lines into 36 squares, each containing one square mile (640 acres), called a section. Each section is generally divided still further into quarter-sections of 160 acres each; these tracts of land are often subdivided. All 
these divisions are described by the points of the compass. The sections in a township are numbered east and west, west and east, alternately. The northeast section is always No. I and the southeast section is always No. 36 .

A Township with Sections

Subdivisions of a Section. Numbered.

Diagram A.

\begin{tabular}{|c|c|c|c|c|c|}
\hline 6 & 5 & 4 & 3 & 2 & 1 \\
\hline 7 & 8 & 9 & 10 & 11 & 12 \\
\hline 18 & 17 & 16 & 15 & 14 & 13 \\
\hline 19 & 20 & 21 & 22 & 23 & 24 \\
\hline 30 & 29 & 28 & 27 & 26 & 25 \\
\hline 31 & 32 & 33 & 34 & 35 & 36 \\
\hline
\end{tabular}

Diagram B.

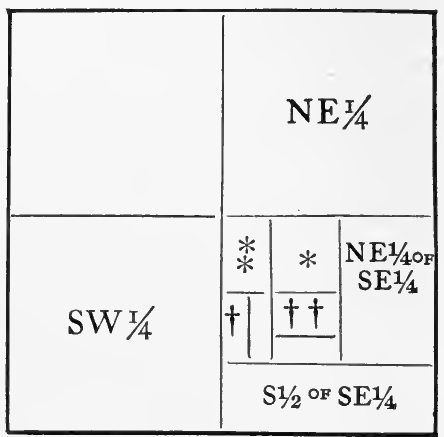

3. Problems. Describe divisions marked, $*, *, t, \dagger \dagger$, and give area of each.

Locate the following pieces of land:
I. $\mathrm{Nw} / / 4 \quad n w 1 / 4 \quad S 6.12$
8. $\mathrm{St} / 2$ nwt/4 Sr.
2. $\mathrm{E}^{\mathrm{T}} / 2 \mathrm{~S}^{\mathrm{T}} / 2$ SI2.
9. $\mathrm{S} 1 / 2 \quad$ sw $1 / 4 \quad \mathrm{~S}_{7}$.
3. $\mathrm{N} 1 / 2$ ne1/4 $\mathrm{S}_{3} 6$.
10. $\mathrm{S} 1 / 2 \mathrm{~s} / 2 \mathrm{sw} 1 / 4 \mathrm{~S} 31$.
4. $\mathrm{S} 1 / 2 \mathrm{n}^{1} / 2$ sw $1 / 4$ S 27 .
II. $\mathrm{Ne}^{\mathrm{I}} / 2 \mathrm{ne}^{\mathrm{T}} / 2 \mathrm{~S} 35$.
5. WI $1 / 2$ se $1 / 4$ Sio.
12. Read and explain:
7. $\mathrm{Se} 1 / 4$ sw $1 / 4$ Si5.
Tp. 4I n R. 14 e 3rd P. M.

NotE.-This is the congressional or school township, for the city of Evanston. It has two school districts, Nos. 75 and 76. Find the number of your township and school district.

VI. Convergence of the Meridians. Converging meridians, because of the convexity of the earth, make ${ }^{12} \mathrm{~S} 6, \mathrm{~S}$ 2 2 , etc., refer to the section number. 


\section{TOWNS AND TOWNSHIPS IN ILLINOIS $6_{3}$}

necessary new base lines and guide meridians every fortyeight miles in the latitude of Illinois in order to correct the discrepancies in the size of the townships. Six of the principal meridians of the United States are numbered and the remaining eighteen are named. The greater part of Illinois is surveyed from the third principal meridian running through the mouth of the Ohio River. Its base line crosses it at Centralia in Jefferson County. Parts of Illinois are surveyed from the second and fourth meridians.

Every civics pupil should understand the township survey system used by the United States Government. An excellent account of the township survey system is found in Government of Illinois, by Harry Pratt Judson, pp. 3037. See also Currey, Hist. of Chicago, Vol. I, pp. 226, 227; James and Sanford, Government in State and $\mathrm{Na}$ tion, Revised Edition, pp. 280-283; also Townsend, Illinois and the Nation, ch. i. Any commercial arithmetic will also give space to the topic.

\section{SUGGESTIVE QUESTIONS}

(For pupils living in counties under township organization.)

I. When is your township election?

2. What township officers do you elect?

3. How do you care for the poor in your township?

4. How many townships in your county?

5. Bound the one in which you live.

6. (a) What was done at your last town-meeting? (b) How many voters attended? (c) Ought the town-meeting to be abolished? (d) Who would do its present work? (Ask the town clerk to let you see the report of that meeting.)

7. What does it cost to run your township?

8. For what is the money spent?

9. Can women vote for township officers in Illinois? Can they serve as township officers? 
64 ACTUAL GOVERNMENT IN ILLINOIS

Io. For what offices are women especially fitted? (Give reasons for your answer.)

II. Has your township good roads? If not, how can you get better ones?

12. How do bad roads increase the cost of living?

I3. Who are the justices of the peace in your township?

I4. Who assesses the property in your township?

I5. Who collects the taxes in your township? 


\section{CHAPTER IV \\ COUNTY GOVERNMENT IN ILLINOIS}

REFERENCES :

I. Town and County Government in Illinois, J. A. Fairlie, in Report Joint Legislative Committee, 47th General Assembly, Vol. II, pp. 7G-132. This is by far the most thorough report on this subject. Get from Secretary of State, Springfield.

2. Annals American Academy, May 1913, is devoted entirely to county government and is very valuable.

3. Greene: Government of Illinois, pp. 95-99.

Local government is "neighborhood government," or "home rule." The county, city, village, township, sanitary, school, and park districts are the local governments in Illinois and perform the duties of social, or community, service.

The county is the largest local government within the State, and touches the lives of the greatest number of people. Illinois has IO2 counties, ranging in area from less than 200 to over I,000 square miles, and in population from I,000 to over $2,400,000$. The principal work of the county in Illinois is to

(I) Levy and collect taxes.

(2) Administer justice.

(3) Have charge of the local charity service.

(4) Have charge of elections.

See American Republic, pp. 163-165. How many of the officers there named does your county have? (Write 
your county clerk for a copy of the county budget, or appropriation bill, to answer this question.)

County Boards. County boards in Illinois are of three types: A board of three commissioners elected at large in the seventeen counties not under township organization; a board of supervisors, elected one from each town, in the eighty-four counties under township organization; a board of fifteen commissioners in Cook County, ten elected from Chicago and five from the rest of the county. The boards of supervisors are frequently too large for efficient government, LaSalle County, for instance, having over fifty members.

"Non-Township" Counties. There are seventeen non-township counties now in Illinois. They are generally small in area and are in the southern part of the State. The list includes Alexander, Calhoun, Cass, Edwards, Hardin, Johnson, Massac, Menard, Monroe, Morgan, Perry, Pope, Pulaski, Randolph, Scot, Union, and Wabash. In I907, two counties, Henderson and Williamson, adopted township government by popular vote. These seventeen counties elect three county commissioners for a term of three years, one being chosen each year. This board of commissioners is the chief executive and legislative authority in the county, holding five regular meetings each year to transact all county business. These "non-township" counties are divided into precincts for election purposes and road districts for highway purposes.

County government in Illinois shares the faults of such government throughout the United States, and is too often a "tax-eater" without showing commensurate benefits. It is "like a big touring-car with the engine going, the clutch on, but no driver in the front seat." A "driver" 
is too often found in the county boss who distributes the county patronage. Complete relief can only come through amending the State constitution.

Three things need to be secured to make county government more efficient in Illinois:
A. Unity of organization (fewer officers).
B. Administration by experts.
C. Simplicity of citizenship through a shorter ballot. (Elect fewer officers on one ballot.)

"You can not get good service from a public servant if you can not see him, and there is no more effective way to hide him than by mixing him up with a multitude of others so that they are none of them important enough to catch the eye of the average work-a-day citizen."'-Roosevelt's Columbus Speech, IgIz.

Study the duties of the executive and judicial officers of the county through those of Cook County. Are any of these officers omitted in your county? About eight counties outside of Cook have a separate probate judge. Half a dozen counties, notably Adams and Sangamon, have a special juvenile court and a separate juvenile detention home.

The usual county officers are the county board, sheriff, coroner, county clerk, treasurer (who also acts as assessor in the non-township counties), superintendent of schools, State's attorney, county surveyor, county judge, clerk of the circuit court, who also acts as recorder unless 'a county has more than 60,000 population, when a recorder of deeds is elected. In each county outside of Cook there are elected from nine to thirteen officers. 


\section{COOK COUNTY}

Early History. Cook County was organized by act of the General Assembly, January 15, I83 I, in the "winter of the deep snow," and included the present counties of Lake, Dupage, Cook, and Will.

The county was named in honor of Daniel P. Cook, formerly Illinois representative in Congress. The little town of Chicago, not yet incorporated, was made the county seat. In June of the same year the Legislature granted the new county twenty-four canal lots containing land which had been given to Illinois by the United States to encourage the construction of a canal to connect the Great Lakes and the Mississippi. Part of these lots were sold to defray the current expenses of the new county, but eight lots were set aside for a public square to be always used for government buildings. This square is now the site of the Court House and City Hall and was originally a gift to the new county from Illinois. On this block of land was erected the first public structure, called the "Estray Pen," a small wooden, roofless enclosure, the first "pound." See Governmental History of Chicago, by Hugo S. Grosser.

In the autumn of I835 the first court house was built on the Clark and Randolph Street corner of this public square. It was a small one-story brick building with a basement in which were the county offices, while the court room, seating two hundred persons, occupied the floor above. That insignificant brick building, contrasted with the present five-million-dollar court house on the same site, is a symbol of the growth of Cook County in eight decades.

Area and Population. The area of Cook County is over I,OOo square miles. It ranks third in Illinois in size 


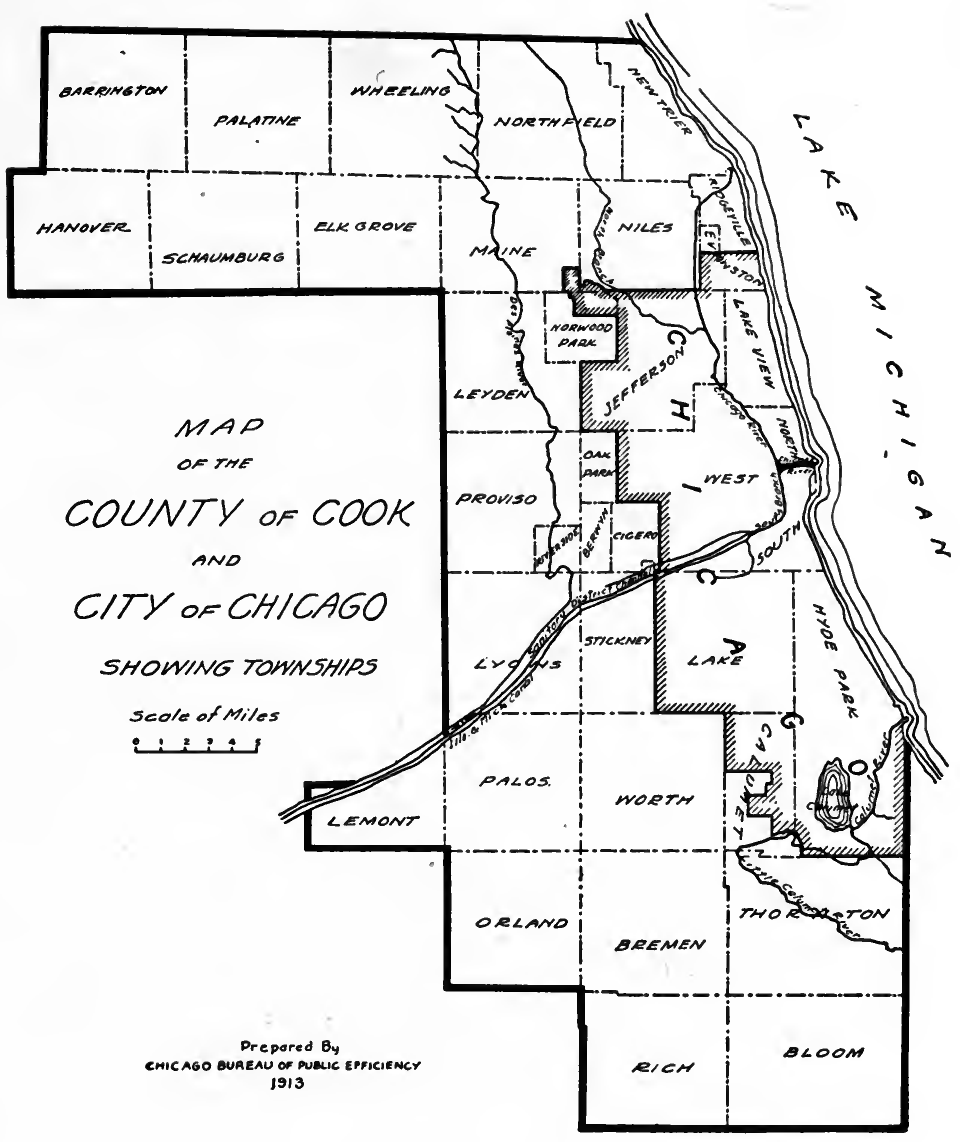

See Appendix D, p. 225, note I, ch. III. 
(McLean and LaSalle are larger), although first in population. The population of the county, outside of Chicago, is about 200,000. Chicago has now over 2,400,000 inhabitants.

Townships in Cook County. There are thirty-seven townships in Cook County, eight of these lying wholly within Chicago and their town governments since 1903 have been largely merged in the city. There are also several consolidated townships like "Town of the City of Evanston," which was formed, I9I6, by vote of the county board from parts of Niles, New Trier, and Evanston. Consult ch. iii on Tozens and Toz'nships.

\section{GOVERNMENT OF COOK COUNTY}

Study the Chart of the Government of Cook County, p. 87 , in connection with this chapter.

County Board. (I) The county board of Cook County consists of fifteen commissioners, ten elected from Chicago by the voters of the city and five from the county outside of Chicago. The voters choose at the same election a president of the county board who must also be elected as a commissioner. This officer must be voted for twice, once for commissioner and again for president of the board (Act of I 893). The appointments of the president of the board must be confirmed by the commissioners except three civil-service commissioners, who are named by the president alone. The board must let all contracts for work to be done, after advertising for bids, to the lowest responsible bidders. As these county contracts involve millions of dollars, this is a wise precaution.

TERM. The term of office of Cook County commis- 
sioners is now four years beginning with the first Monday in December, 1914, when the new board took office. (Act General Assembly, I9I3.)

Duties. The principal work of the board is connected with the annual budget, which must be passed by March Ist each year. The board is divided into standing committees named by the president, and their titles show their duties: public service, finance, roads and bridges, legislation, building, and civil service. The deputy comptroller of the county acts as clerk of the board at all its meetings and is responsible for the minutes or records. The powers of the Cook County board are very exactly stated in the Revised Statutes, ch. xxxiv, art. 62.

Executive Officers. The president of the county board presides at all meetings but casts only his regular vote as a commissioner. There is no way to settle a tie except by reballoting. $\mathrm{He}$ appoints the warden of the county hospital; superintendent of the poor house and tuberculosis hospital at Oak Forest; three civil-service commissioners; ${ }^{1}$ the county agent, who administers all outdoor relief and any special help needed by old soldiers and sailors or their families; superintendent of the Juvenile Detention Home, who has always been a woman, although the law does not require it; superintendent of public service, who buys all supplies for the county offices and institutions; county attorney, who acts as legal adviser for the board and represents the county whenever suits are brought against it; county architect, who draws the plans and oversees the erection of all buildings owned by the county.

${ }^{1}$ Cook County had the first woman civil-service commissioner in Illinois, Miss Anna E. Nicholes, appointed by President McCormick, February I, 1913. (2) 
Any appropriation of money over five hundred dollars must be passed by a two-thirds vote, ( Iо) of the board. The president has the right to veto any item he chooses in the annual appropriation bill, and such items can only be restored to the budget by twelve votes, or four-fifths of the board. In the hands of a vigorous president this power is capable of doing much good in defeating " salary grabs and pay-roll padding" on the part of a corrupt majority of the board members.

The Cook County budget for I9I3 had about nine hundred items vetoed by President A. A. McCormick, the largest use of the veto power ever made by a Cook County president.

The budget as finally adopted carried appropriations for more than \$15,295,000 for I9I3. Any governing body that has the legal right to spend over $\$ 15,000,000^{2}$ of public money in one year-I913-ought to be well known, carefully chosen, and diligently watched by every citizen.

Sheriff. The sheriff is the arm of the judge, or " court messenger," because he carries out the orders of the judge. He sells property for debt; takes a prisoner to jail, or hangs him, if the judge so orders. To help keep peace in the county, the sheriff appoints deputies (in I9I6, 28 , and 128 bailiffs, similar to special policemen, to serve in the courts), but he is responsible for their acts. He appoints the jailer of the county jail and is responsible for the care and safe-keeping of its prisoners. By act of Legislature, 1905 , if a person in the custody of the sheriff is lynched, the governor shall remove the sheriff from office.

2 Cook County appropriation bill, I9I3, n. II, total appropriations. 
The contract for feeding the prisoners in the jail is now let by the superintendent of public service to the lowest reliable bidder and costs Cook County, this year, \$30,000. Formerly the sheriff was paid twenty-five cents per day for feeding each prisoner and had all he could make. The office of sheriff was then a fee office and worth from $\$ 75,000$ to $\$ 100,000$ a year, one of the "richest plums on the county political tree." Since I909 a salary of $\$ 9,960$ has been given the sheriff and the fees are now paid into the county treasury. Why is this a better arrangement? The sheriff and county treasurer can not be reëlected. Why?

County Clerk. The county clerk holds three offices because of his election to the office of county clerk. He is ex-officio comptroller and must make all estimates of expenses for every department of the county government; is clerk of the county court and responsible for its records although he does none of this work personally; keeps all important county papers and the county seal; issues marriage licenses; issues hunting licenses for the state. For his work on the taxes, see ch. v, pp. 97-98. He maintains three separate offices to perform these varied duties as county clerk, comptroller, and clerk of the county court, and employs several hundred men and women, none of whom is under civil-service rules. Only a few of the more experienced employees are appointed strictly because of efficiency.

County Treasurer, who is ex-officio county collector. He pays out as well as receives all county funds, on the warrant of the county comptroller. His bond hereafter is not to be less than $\$ 3.000,000$, but in justice to the treasurer, the expense of carrying such a heavy bond is to be borne by the county. Formerly one of the unsolved puz- 
zles in Cook County government was the amount the treasurer received for his services as county collector for delinquent taxes. The law provided an utterly inadequate salary for the office and allowed a certain percentage of the delinquent tax collections for the various towns in the county. The legislature of I9I5 amended the law by providing a fixed salary of $\$ 9,960$ for the treasurer and hereafter all fees and percentages received from this office must be paid to the county.

The law also allowed the treasurer to pocket all the interest paid by the various banks on the county funds deposited with them. The exact amount was unknown, as the treasurer always insisted the interest agreement was a private matter between the banks and himself. Here also the statute has been amended and now all such interest on public funds will belong to the county in simple justice to the taxpayers.

Coroner." If a person is found dead under any suspicious circumstances, or there is no physician's certificate stating cause of death, then the coroner, or his deputy, must investigate. A jury of six persons is summoned and an inquest is held by examining witnesses to determine the cause of death. If evidence of crime is disclosed, a warrant for the suspected person is sworn out by the State's attorney. Arrest, indictment by the grand jury, and the trial may follow, if such suspected person can be found. The coroner is the only person who can arrest the sheriff, and he acts as sheriff if the latter at any time is unable to serve.

${ }^{3}$ American Republic, p. I62. 
The two offices are the oldest in the entire county, and date back to the English "shire reeve" and "crowner," the king's personal representatives in the shire, or county.

Recorder. All deeds and mortgages must be recorded at the county seat. In Cook County a special officer is elected for this work, but in most counties the county clerk is ex-officio recorder of deeds. The county and State must know who owns every parcel of land within its borders, and whether there is a mortgage on it. Why is this necessary? How does such a record protect the owner as well as the county and State?

Superintendent of Schools. For the duties of this officer, see chapter on Public Education, p. I68. He is particularly required to supervise and assist the rural schools. Beginning September 19I3, the Cook County superintendent has appointed five rural directors, each one to have charge of the country schools in his district comprising the different townships in the county. These directors are to oversee the teaching of agriculture in the country schools; to encourage the wider use of the schoolhouse as a social center, and direct the forming of corn clubs, vegetable-canning, fruit- and chicken-raising clubs among the boys and girls. This movement to help the country school educate the country boy and girl for the farm life, not away from it, is one of the hopeful signs of the growth of practical education in Cook County rural schools.

Surveyor. Whenever necessary, the 'surveyor determines the right boundaries of property by a survey. He is paid by fees. Why elect such a petty officer? His name only encumbers the ballot.

State's Attorney. The State's attorney, elected for four years at the general election in November, is the pub- 
lic prosecutor and legal representative of Illinois in Cook County. His office is of great importance because he must prosecute all offenders indicted by the grand jury if they are ever punished. If the State's attorney is weak or dishonest, the county will lack protection against law-breakers. A faithful State's attorney is a terror to criminals. He appoints his own assistants, - at present about forty and unfortunately often uses this power to reward political friends, and the administration of justice in the county often suffers from lack of able legal service. Should the State's attorney fail to do his duty, any one of the judges may name a special State's attorney and grand jury to investigate and prosecute any case. Such a special attorney and grand jury were named by one of the circuit judges (July, I9r3) to investigate charges of fraud in the general election of November 5, I9I2. Indictments resulted. A general election is one where any State officer is elected.

\section{STATE COURTS IN COOK COUNTY}

There is a circuit, superior, appellate, criminal, and juvenile court in Cook County, all of which are State courts, but serving that county alone. There are thirtyeight circuit and superior judges elected in the county, any one of whom may hold court. The number of judges depends on the Legislature, which also fixes their salaries; for Cook County, \$10,00o (4), half to be paid by the State, half by the county.

The circuit judges are all elected the first Monday in June, the superior judges at different times. The term of both is six years. The jurisdiction of each court includes civil and criminal actions, and cases appealed from 
the justice, county, and municipal courts. The judges themselves select certain of their number to sit in the criminal court and one judge to preside over the juvenile court, where boys under seventeen and girls under eighteen are tried and the cases of dependent children settled.

Clerks of the Courts. There is an elected clerk, each at a salary. of $\$ 9,000$, for the circuit, superior, criminal, appellate, and probate courts; the term is six years, and they are elected in November. In the interest of economical, efficient government, these clerks ought to be appointed by the judges of the courts they serve and the judges held absolutely responsible for the work of their appointees.

The three appellate courts for Cook County will be described under the judicial department of Illinois.

Juvenile Court. This is one of the State courts of Cook County. The "right hand" of the judge is the chief probation officer, chosen after a competitive examination and paid \$3,000 per annum. There are now (I916) over eighty assistant probation officers, men and women, selected in the same manner as their chief. Their work is to watch over and befriend the delinquent and dependent children, boys up to seventeen, girls to eighteen years of age, committed to their charge as "wards of the court." (Look up the meaning of " delinquent" and " dependent.")

Cook County has the honor of possessing the first juvenile court in the world, established by act of the General Assembly, 1899, preceding the Denver, Colorado, court (Judge Ben Lindsey) by six months. Circuit Judge Richard A. Tuthill was the first "kid" or "kindergarten judge," as his associates dubbed him, and organized this noted court.

The juvenile court in Cook County has the additional 
distinction of having the first woman assistant to the judge in the State, Miss Mary E. Bartelme, who acts as assistant to Judge Arnold and hears all cases of delinquent girls. Miss Bartelme was appointed by Judge Pinckney in March, 19I3. Her "legal position" is more like a master in chancery and the judge enters all orders of the court.

The Juvenile Detention Home is a temporary home for all children awaiting the action of the court, and is supported equally by Chicago and Cook County. A careful physical examination is given every child on entrance (5), and medical and dental treatment when necessary.

The home is under the charge of a woman superintendent, selected through competitive examination, and there are five teachers furnished by the board of education, two each for the delinquent boys and girls and a kindergartner for the dependent little children. In I9I4 a new school building was erected by the Chicago board of education exclusively for the children in the Juvenile Detention Home. The building provides a gymnasium, shower baths, court playground, manual training and domestic-science equipment, library, and all the facilities of a modern schoolhouse. The need of such a school building was great. (6)

The probation department of the juvenile court is organized under four divisions: Field, Probation, ChildPlacing, and "Funds to Parents." The latter is popularly called the "Mothers' Pension" division, and was difficult to administer, because the law was loosely drawn. A new law, carefully drawn, was later passed and has proved workable. The persons eligible, amount of pension, previous investigation required, are now clearly stated in the new law. The Pension Fund is administered through a committee consisting of the chief probation officer, the head of the Moth- 
ers' Pension department and the County agent. This committee with the probation officers decide amount of pension to be granted each worthy applicant. The county board appropriated $\$ 185,000$ in 1916 for this Parents' Pension Fund.

During November, 1915, there were 1,728 children under fourteen years of age in the families receiving funds in Cook County. The families numbered about five hundred and forty and the average amount given per child was $\$ 8.52$ for the month. A visiting housekeeper advises these mothers about the best way to spend this money for the best good of the children.

The object of the law is a good one: to keep families together and enable widowed mothers with small children to care for them at home, instead of being obliged to put them in a public institution. Great care in administering the law is necessary to prevent pauperizing worthy families. (7)

Four types of children come before the Juvenile Court truants, defectives, dependents and delinquents. Truancy cases must be handed over to the school authorities. However, the probation officer works with the truant officer to save the child from a life of vagrancy or crime.

Formerly the greatest difficulty was with the defective type. Under the new law of I9I5 to provide care for the feeble-minded, children so afflicted can be sent to a public or private institution, or placed under a guardian with parental powers. If the judge so orders,- after a commission of three, two of whom must be experienced physicians - or one may be a psychologist, have passed on the cases, - "the children can be placed in custody of the state for life, thus protecting communities against their depredations and also giving the children needed care."

The Juvenile Court should be enrolled as a preventive 
agency. The probation officers are the means of settling a large number of cases out of court by bringing parents or guardians and children in friendly fashion before the chief probation officer so that the boy or girl can then be placed directly under the charge of a probation officer. Thus a formal complaint to the court is avoided and the child is saved from the disgrace of a trial. (8)

The county judge is elected for four years and holds the county court. He appoints the three jury commissioners for Cook County; hears all cases of persons said to be insane and assigns them to one of the State hospitals for the insane. To assist him in this work he calls a jury of six persons, only one of whom must be a physician. Judge Owens three years ago summoned juries of prominent women to hear the cases of women and girls said to be insane. Their good work won recognition because they were the first women jurors in Illinois. Cases of non-support and desertion also come under the jurisdiction of the county judge. See Charity Service Cook County, p. 85 . The county judge hears cases of election frauds and is responsible equally with the election commissioners for carrying out the election laws. Civil suits involving sales of property for taxes come before the county court.

\section{Probate Court, or “ Orphans' Court."}

I. General Statement. This court is held by the probate judge, elected for four years by the voters of Cook County. Seven counties now have a separate probate judge. The work of the probate court is to probate (prove) wills; appoint guardians for minors with property and for adults, incapable through insanity or drunkenness, of managing their own property; ap- 
point an administrator to carry out the terms of a will where no executor is named in the will.

II. Procedure in Probating a Will.

a. Petition to judge for probate: will must accompany petition.

b. Citation (summons) to persons interested.

c. Hearing the proofs by judge:

I. That testator is dead.

2. That testator was of sound mind and not unduly influenced when making the will.

3. That it was the last will and testament.

d. Admission to probate and letters testamentary issued by judge to executor. Why?

e. Executor sends notice to creditors.

f. Executor has inventory of estate made.

g. All claims against estate audited. Why?

h. Division of property according to will and recording of all transfers of real estate in county recorder's office.

Give a reason for each of these steps.

There are three general divisions in probating a will:

I. Proving the will.

2. Paying the debts.

3. Dividing the property.

III. Procedure where Person Dies Intestate, that is, where No Will is Left.
a. Petition to judge for administrator.
b. Proof of death of person (doctor's or coroner's certificate).
c. Letters of administration issued.
d. Remaining steps same as for will except final division of estate is according to law; which recognizes only heirs.

IV. Suggested Questions on Wills.

I. What is a will? Must it be in the handwriting of the testator? How can a person who can not read or write make a will? 
2. Why must there be witnesses? How many? Must they know the contents of the will? Can they be remembered in the will?

3. If a witness dies before the testator, how may the will be proved?

4. What is a codicil?

5. What is the difference between an heir and a legatee?

6. Why is it better to make a will?

7. What hinders a guardian from abusing his trust?

8. How can an animal be a legatee? An institution?

Jury Commissioners. There are three jury commissioners, appointed by the judges of all the courts in Cook County; salary not over $\$ 1,500$. Old soldiers must have preference in appointments. The jury commissioners must keep on file a list of men eligible for grand and petit jury duty in the county and State courts. At least I 5,000 cards containing the name, age, occupation, nationality, of men eligible for the juries are in a large swinging box, hung in a frame, in the jury commissioners' rooms. The names for the cards are secured from the poll lists kept by the election commissioners. Sixty thousand names, eligible for petit jury duty, are kept on file all the time and a separate list of three thousand men owning real estate, eligible for the grand jury.

How Juries are Drawn. The clerk of any court requiring a jury goes to the commissioners, and after the violent shaking up of the box containing these cards, he draws out as many as his "panel" (number of jurors needed) calls for. Then venires (summons to appear as jurors) are served on these men.

The jury commissioners have succeeded in securing better men for jury service in Cook County and in saving time for the judges, 


\section{CHARITY SERVICE OF COOK COUNTY}

The charitable institutions of Cook County are the largest in the United States, those in New York being under the city. More than one-half of every dollar of taxes appropriated by the county board each year goes to support the charity service of the county. This fact alone ought to kindle the interest of every citizen in his or her county government. The list of charitable institutions follows:

a. Infirmary or poor house at Oak Forest. This institution shelters 3,000 old and infirm persons. It is located southwest of Chicago on the county farm of 355 acres in Bremen Township. A very successful farm is run in connection with this institution. The labor is provided mainly by the inmates and the farm furnishes large quantities of fresh vegetables in season for the Infirmary and Tuberculosis hospital. A flourishing poultry yard, an orchard, vineyard, greenhouses and cannery prove Oak Forest is moving toward partial self-support.

b. County hospital. The new hospital building, when completed, will have 2,700 beds and will be the second largest hospital in the world. Physicians and surgeons come from all over United States, Canada and even South America to visit or study in this hospital. Medical students in Chicago are ambitious to be admitted as internes because of the great opportunities for study and practice.

r. Psychopathic or Detention hospital, on the west side, is for the temporary care of men, women, and children thought to be insane and waiting until the county judge and a jury pass on their mental condition. A new modern hospital properly equipped to care for these pitiable cases was built in I9I4 at a cost below the bond issue - a very 
unusual fact where buildings are paid for from tax-money.

This hospital has recently established a department of psychiatry (9) for the study and treatment of mental diseases. Here can be sent cases of nervous disorders bordering on insanity where wise, kindly treatment may restore the patient to normal life without the stigma resulting from commitment to an insane asylum.

d. County agent administers the outdoor poor relief and gives temporary relief to the poor in their homes. With the advice and assistance of the G. A. R. posts, he distributes county aid to needy soldiers and sailors and their families. The county is spending (in I9I6) over $\$ 574,000$ in outdoor relief through the county agent's office. (Io) An earnest effort is being made to prevent misuse of this large sum by compelling certain unworthy " political poor" to go to work. It is estimated a hundred thousand dollars will be saved and not a single worthy family be turned away.

e. Juvenile Detention Home for Delinquent and Dependent Children is described under the sections on the Juvenile Court of which the Home is a necessary part. Sangamon and Adams Counties also have such homes connected with their juvenile courts.

f. Adult-Probation Officers. ${ }^{4}$ These adult-probation officers are to have oversight of "first offenders" and young prisoners who are too old for the juvenile court yet show desire to reform. These prisoners may be paroled to an adult probation officer for six months or a year and, if proved deserving, may be dismissed by the circuit judge at the end of their parole without further punishment. Part of the earnings of such paroled persons must go to people dependent on them for support, and part to make

4 Act in effect, July I, I9II. 
good any losses their crime caused. This proves their determination to do right and their fitness for complete freedom. The law is very carefully drawn and ought to accomplish much good if wisely administered. It is under the supervision of the circuit and municipal court judges.

g. Cook County maintains two large hospitals to care for cases of tuberculosis, one connected with the County hospital for cases that are counted incurable, or where the patient is too near death to endure the long trip to the County farm, and the larger hospital with 800 beds at Oak Forest. This hospital is on the cottage plan and in I9I5 admitted over I,500 patients. Within two years the hospital population has doubled, which proves the growth of public confidence in the institution and in its power to cure. The long campaign against the "white plague" is bearing fruit. Each year more people in the incipient stages of tuberculosis seek the help offered by the Oak Forest Hospital.

h. Bureau of Social Service of Cook County was created by the County board March I, I9I6. It combines all the public welfare and social service work of the county under one director, at present a woman and a trained social worker, who is under civil service protection as are all the twenty employees of the bureau. The organized divisions are (I) Non-Support, dealing with cases of deserted mothers and children, or where because of physical disability crippled children and aged parents are unjustly thrown on public charity. This division collects from relatives financially able to contribute toward the support of such cases, about $\$ \mathrm{I}, 000$ each week of the year and thus saves the taxpayers about three times the appropriation for all the work of the Bureau of Social Service. (2) County Jail division. This deals with cases of boys between I7-2I, too old for the 
juvenile court and held to the grand jury, often for a first offense. Their cases are investigated and as a result, the boy is often paroled to an adult probation officer and sent back to work, thus being saved the degradation of weeks in jail in contact with vicious men. (3) Psychopathic division to investigate home conditions and family histbry of the cases committed to the Psychopathic hospital. Such investigation is very necessary before a case can be successfully treated by the hospital staff. (4) Oak Forest division to look into the cases of children sent to the Infirmary and Tuberculosis hospital. In the past, large numbers of crippled and feeble-minded children were sent to the Infirmary which is not supposed to keep them. The state has now made more suitable provision for their care and it is the duty of this division of the County Bureau of Social Service to see that the state law is carried out and that such children are committed to proper institutions. (5) Tuberculosis Survey of Toznships in Cook County outside Chicago. Within that city, the Municipal Tuberculosis Sanitarium and the health department are responsible for such survey. The county survey is part of Cook County's preventive campaign against this wide-spread disease. (6) Investigation of releases from the Lincoln State School. The title of this division explains its work. Before a feeble-minded child or adult is released from state custody, careful investigation is needed to determine whether the person set at large is capable of self-direction and will not be a menace to any community receiving such person. (7) Marriage and divorce statistics from which officials can obtain valuable information on which to base future legislation. 


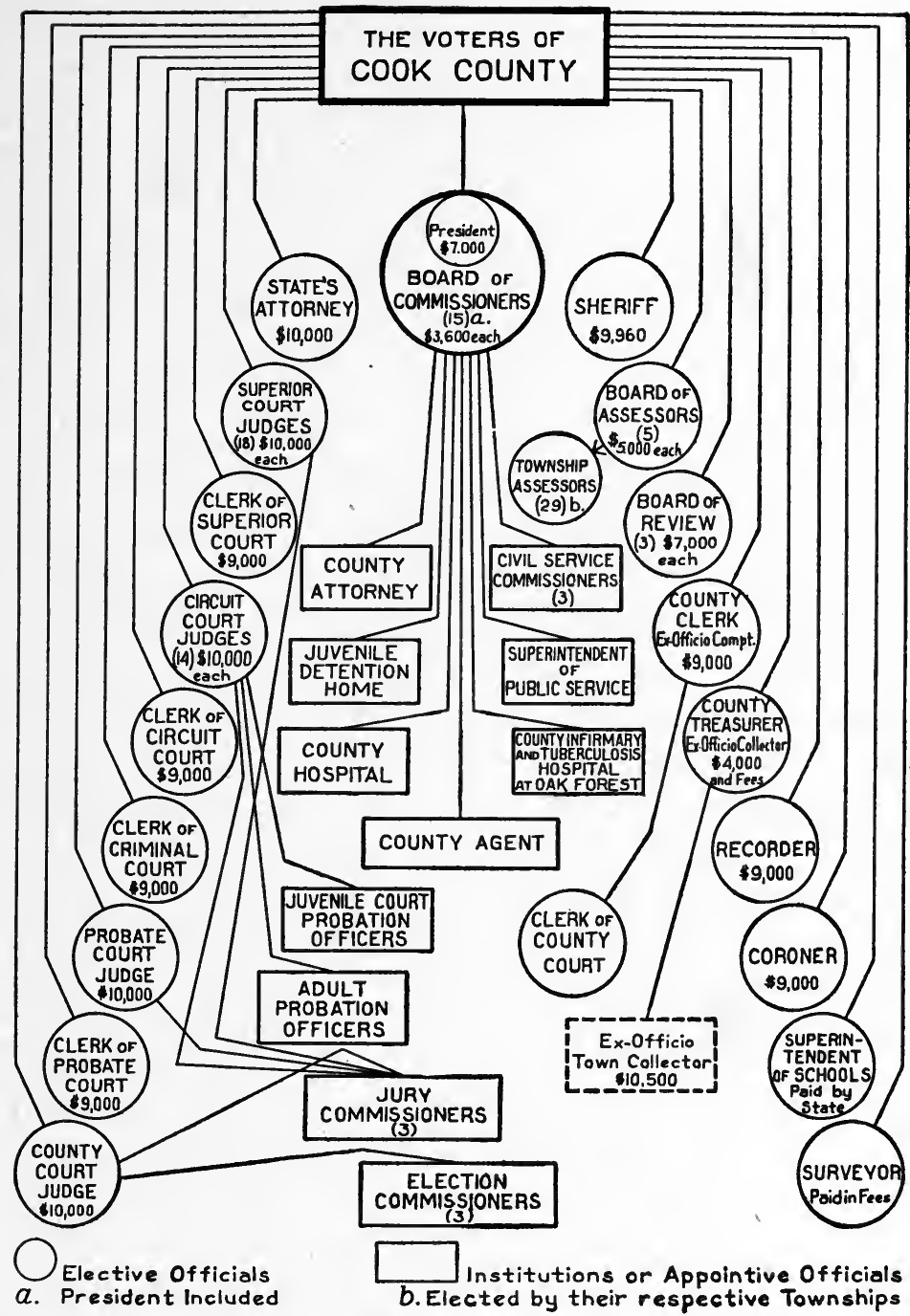

Prepared by Chicago Burean of Public Efticiency, 1913

Chart of organization of the government of Cook County, Illinois, showing lines of authority and salary rates for elective officials. 


\section{CHAPTER V}

THE PUBLIC POCKETBOOK: HOW IT IS FILLED ${ }^{1}$

REFERENCES :

I. Revenue Law, Revised Statutes, ch. I20; consult index at beginning chapter.

2. Report Special Tax Commission: J. A. Fairlie, I9io.

3. Greene: Government of Illinois, ch. ix.

4. Garner: Government in United States; Supplement, pp. 28-32.

5. A. Tax-Payer's Calendar: County Clerk of Cook County, Chicago.

General Statement. The main source of Illinois' revenue is the general property tax, levied on real and personal property. The most striking feature of this tax is the legal recognition in the revenue act of the State of the undervaluation of real and personal property for assessment. Since I909 the "taxable value" has been onethird of the "fair cash value."

Corporations. Corporations in Illinois are subject to taxation in the same manner as individuals; but railroad and telegraph property is assessed by the State Board of Equalization. Each county, however, is allowed an assessment for the miles of track lying within it. The same is true for the telegraph companies on their mileage of poles and wires in each county.

${ }^{1}$ Much of this material is given through the courtesy of Mr. Charles Krutckoff, head clerk under the Cook County board of assessors. 
Sources of Illinois' Revenue. The income of the State of Illinois is derived from:

A. General tax on property of individuals and corporations.

B. Seven per cent. on gross income of the Illinois Central Railroad. By the act of $185 \mathrm{I}$, on all its charter lines in the State, the Illinois Central is to pay annually to the State, 7 per cent. on the gross receipts of the corporation. This payment is in lieu of any other tax on valuable lands given the railroads by the State, and is supposed to be a perpetual agreement. Illinois receives over $\$ \mathrm{I}, 200,000$ annually from this source.

C. Tax on gross premiums of all life insurance companies.

D. Inheritance tax on all property probated in the State. This is easy to collect because the value of the property is a matter of record in the probate court. The tax is a graduated one; widows and children pay less than more distant relatives.

E. Certain fees and miscellaneous items, as fines. Towns and road districts may levy a cash poll tax of from one to two dollars for road purposes only. Illinois has never had any general poll tax as many other States have. (Session Laws, 1913.)

Property Exempt from Taxation. The State of Illinois is liberal in kinds of property exempt from general taxation. Such property, however, must pay its share of any special assessments levied. The classes of property exempt are :

A. All public school lands and buildings.

B. Other educational institutions of all kinds; $e$. g., the Art Institute in Chicago, Northwestern University at Evanston.

C. Churches; parsonages if owned by the church.

D. All government property.

E. Public libraries: e. g., Newberry and John Crerar in Chicago, as well as the city-owned public library.

F. Cemeteries. 


\section{Terms Defined. (To be carefully learned.)}

A. Real property: lands and buildings.

B. Personal property: movable and "intangible" property; e. g., cattle, threshing machines, furniture, automobiles, sewing machines, watches, stocks, and bonds, etc.

C. Personal property schedule: a list of the kinds of personal property for purposes of taxation.

D. Assessment of property: putting a value on property for purposes of taxation. Assessed value is one-third the market value.

E. "Levying a tax" : saying how much money must be raised in a certain locality to run the government.

F. "Computing the rate" : finding how much must be paid on every hundred dollars of assessed value of the property.

G. "Extending the taxes": multiplying the assessed value of the property by the rate of taxation and entering same in tax-collector's book.

H. Special assessments are taxes levied for some special purpose, as paving a street, laying a sewer or water main, and are only paid by the property benefited by the improvement. These taxes frequently form the heaviest ones against city real estate. They are usually paid to a special officer called city collector, and are never included in the general property taxes.

\section{Assessment of Property in Cook County. (General} features are the same for all other counties in Illinois.)

A. Personal Property.

I. Cook County has an elected board of five assessorsterm six years - to have entire charge of the assess- 
ment of real and personal property in the county. In counties under township organization, outside of Cook, the elected town assessors make the original assessment subject to review by the county treasurer. In the seventeen non-township counties, the county treasurer is ex-officio assessor and may appoint deputy assessors.

2. The personal property schedules may be sent by mail, or delivered by a deputy assessor. In Chicago they are always delivered by the deputy assessors. These deputies are appointed by the board, or elected by the legal voters of the township: they are appointed in Chicago and in Ridgeville Township (Evanston), but elected in the remaining twenty-nine townships in the county.

3. Owner of property must fill out schedule by putting down fair cash value of his personal property. Schedules must be returned to the assessor by mail or in person. In either case they must be sworn to before a notary. After delivery of schedules from five to fifteen days are allowed before adding the legal fifty per cent. to the deputy assessor's estimate of the value of the property. This is only done where the owner neglects, or refuses, to fill out his personal property schedule.

Personal property schedules returned are accepted by the board of assessors. In the busy months of March and April there are from 250 to 300 men under the head clerk of the board of assessors, in the workroom and outside. Need of a thoroughly trained, efficient force of men for all this work is very apparent.

From the field book a careful copy is made of all values on to cards called "slips."

4. All the items and values given on the personal property schedules are absolutely copied on to the Personal Property Tax Warrant. The thirty-eight separate columns on this Personal Property Tax Warrant are added to find total value of all the personal property in the county. 
5. After this tax warrant is completed, the board of assessors sign sworn affidavit as to its authenticity and this statement is attached to the warrant. An alphabetical list of every personal property tax-payer in a district, with full cash value of his movable, or personal, property, affixed, is mailed by the board of assessors to each tax-payer in the county. Every one can thus know how much he is assessed on his personal property and compare it with his neighbor's assessment. These lists form the basis of the complaints made to the board of review. Get such a personal property list for your township if you live in Cook County.

\section{B. Assessment of Real Estate in Cook County.}

I. The assessment of real property is made in a different way, to the bewilderment of the tax-payer. In counties outside of Cook, the assessments are all reviewed by the county treasurer. In all counties except Cook, the real-estate books are only made in duplicate. In Cook County the county clerk makes the real-estate books in triplicate every four years. The books are called A, B, and C. Book A is for the county clerk. Book $\mathrm{B}$ is for the assessors. Book $\mathrm{C}$ is for the board of review. The county clerk.puts the legal description of each parcel of taxable property in each of the three books. Real-estate books are filled out by assessors only once in four years (I), and sent to the county clerk. Each year the assessors simply add the improvements made and new buildings erected during that year and note all fire losses. There are about I3,000 new buildings erected annually in Chicago.

Assessors also keep careful track of all estates probated and note who receives all such property when divided. They ought to work in conjunction with the probate court and the recorder's office, if all county departments worked for the best, most efficient service to the tax-payers of the county. 
2. When the assessors have filled out the actual and assessed value of every parcel of taxable real estate in the county for the first year of the quadrennial period and entered same in the three books, they are sent to the board of review for their corrections, if any are to be made.

Book A alone is sent by the board of review to the county clerk. Book B then stays four years with the board of assessors, and Book C stays four years with the board of review.

Work of the Board of Review. This board of three men, elected for six years, hears all complaints of individual tax-payers. Their salaries are large $-\$ 7,000-$ and they only give about two months of their time each year to the work. The reason for the large salary is not apparent. Between July 7 and August I these complaints, on prescribed blanks, must be filed in person at the rooms of the board. August is given to hearing these complaints.

The assessors' warrants are sent to the county clerk from the board of review as fast as they are completed and all are finished about September I5.

Work of the State Board of Equalization. The State board of equalization equalizes assessments of real and personal property between counties in the State and also assesses railroads and certain corporations, and the State auditor reports these values to the various county clerks. Each of the IO2 county clerks in the State sends the lists of real and personal property for the county to the State auditor, who is a member of the board. The board now numbers twenty-six: one member elected from each congressional district, and the State auditor is a member exofficio. The members are chosen in November for a term 
of four years each. The annual meetings are held in August.

Their work is also to assess railroad tracks, or " right of way," and their rolling stock — cars and locomotives - and to assess capital stock of Illinois corporations. The local assessor looks after the property of foreign corporations doing business in the State.

The work of the board is done through committees and largely through "star chamber" methods. Its rules of procedure are over forty years old and its work is clumsy and inefficient. "It should be abolished and a small tax commission appointed by the governor substituted." 2

Work of County Clerk (on Personal Property). The county clerk is obliged to copy all names, addresses, and assessed values (since 1909 one-third of the real value) of all personal property in Cook County from the assessor's personal property tax warrants sent him from the board of review. This is called the "collector's warrant."

Computing the Rate. The county clerk computes the rate of taxation by dividing the amount of tax to be raised in any township or taxation district by the assessed value of all the taxable property in that district including personal property, real estate, certain railroad property, and capital stock of corporations. Each taxing body (except the State of Illinois) certifies its tax levy, or amount needed from the taxes, to the county clerk for this very purpose. There are about four hundred different taxing bodies - townships, school districts, cities, villages - in Cook County. The rate of taxation has to be found separately for each of these bodies, because there is some taxing

2 Report, Special Tax Commission, John A. Fairlie, Secretary, November I9Io. 
body, for instance, a small park district in one city or village, that is not included in any other, thus making a different rate for that district. The assessed value of each piece of taxable real estate in the county is multiplied by the rate and the amount entered in the assessor's books opposite the description of the property. The amount of a tax-payer's personal property tax is found in the same way, using the same rate, and is also entered in the assessor's books. The sum of these two amounts makes the total of a property-owner's taxes, except special assessments, - a large exception if you live in a city.

To still further complicate the process, the rate for State, county, township, sanitary, school, and park districts must be computed separately, by a similar process. It is easy to understand in Cook County, where the difficulties are the greatest, why the county clerk's office employs three hundred men during November, December, and January, the busiest season, for all the complicated work of " extending the taxes" and entering them in the assessor's books. When the work is finished the county clerk sends the books to the collectors, and the work of the tax-payer begins.

Collection of Taxes. This is easy compared with the assessment of property and extension of the taxes just described. Taxes are due on and after January 2 annually. In all counties under township organization, including Cook, taxes are payable to the town collector until about March I5. Within Chicago, taxes are payable to the county collector, who is also the county treasurer. In the seventeen southern counties not under township organization the sheriff is tax collector.

Delinquent Taxes. Taxes are delinquent April I and must all be paid to the county collector. Interest at 


\section{6}

I per cent. a month is added after May I as a penalty for tardy payment. Two per cent. of the delinquent taxes collected may be retained by the county collector as his lawful fee. This ought to be remedied by a law giving the county collector a fair salary and having all such fees paid into the county treasury. (2)

If the taxes are unpaid August I, the county collector and the county clerk, or their deputy, must sell the real estate at public auction for the taxes.

Redemption of Property. The owner has two years in which to redeem his property at the office of the county clerk by paying arrears of taxes and all other fees incident to the sale. After the two years are up, the owner can only recover his property by making a bargain with the purchaser, who meanwhile holds a tax deed for the property.

Restrictions on the Taxing Power. The Legislature can not contract any debt for the State beyond \$250,000, unless the people, by a referendum vote, approve such bond issue. All local taxing bodies in the State are limited by the constitution, or the laws, in respect to the amount of taxes they may levy. Except by vote of the people, county boards can not levy a tax of more than 75 cents on each $\$ 100$ of the assessed value. City governments are limited to 2 per cent. of the assessed value of property within their boundaries; school-boards are limited to 5 per cent. on the assessed value of property in the district (school buildings excluded), and park and sanitary districts are equally - limited. These percentages are for annual expenditures; the debt limit, or right to issue bonds for public improvements, etc., is in addition to these percentages. This works special hardship on a large city like Chicago, and prevents 


\section{THE PUBLIC POCKETBOOK}

many greatly needed public improvements being started. The General Assembly of I9I3 passed an amendment to the Juul Law which will give some relief by allowing cities to levy larger taxes and thus gain an increased income by I9I4.

Conclusion. This cumbersome and complicated system of assessing property, the taxing of personal property, and the undervaluation of all property, leads to dishonesty on the part of the owners, who never think of reporting all their personal property at its full cash value. Consequently, taxes in Illinois fall heaviest on conscientious people, while rich property owners generally escape their just share of taxation.

Illinois greatly needs a thorough revision and simplifying of her revenue act and an amendment to the constitution to make such revision effective. But to amend our constitution seems almost an impossibility. ${ }^{3}$

The local assessors and the county employees for the assessment and collection of taxes deserve much credit for better work than could be expected under the handicaps of such a confused and complicated law. "The Legislature of I9I 5 refused to provide a small tax commission to supervise and simplify our system of taxation. (3) The Legislature also later refused to abolish the board of equalization.

\section{ILLUSTRATIVE MATERIAL}

Get copies of Personal Property Tax Warrant, Personal Property Schedule, list of personal property tax-payers in your township with the amount of their personal property; a copy of the county collector's warrant - blank sheet,- tax receipts, etc.

Get the assessor to fill out a sample real-estate assessment on a well-known piece of property in your township, or school district,

3 Amendment of the Illinois Constitution, pp. 198-200. 


\section{ACTUAL GOVERNMENT IN ILLINOIS}

and notice what is entered on the assessor's book. If possible, visit the office of the county collector and see the tax books for your school district.

Get a copy of the newspaper in your county with the advertisements of real estate to be sold for delinquent taxes.

Assessment of Personal Property, Town of Ridgeville (4), for I9I5.

Board of Assessors

$\$ 3,213,438$
Board of Review

$\$ 3,066,627$

The assessed or one-third value of Real Estate, bounded by Rush Street bridge to Twelfth Street and from Lake Street to the river, for 1915: (5)

Board of Assessors

$\$ 213,215,572$
Board of Review

$\$ 194,455,379$

The assessed or one-third value of Real Estate in the City of Evanston for 1915:

Board of Assessors

$\$ 10,525,606$
Board of Review

$\$ 10,233,200$

The tax rate in school district No. 75 is divided as follows:

State $\ldots \ldots \ldots \ldots \ldots \ldots \ldots \ldots \ldots \ldots \ldots . .55$

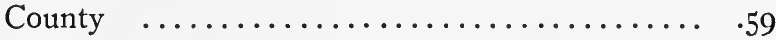

Sanitary $\ldots \ldots \ldots \ldots \ldots \ldots \ldots \ldots \ldots \ldots . .42$

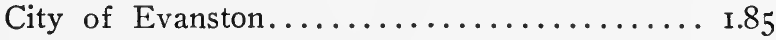

High School ................... I.25

Public Schools .....................2. 2.27

$\$ 6.93$

The above rates are the total rates of all tax levies, except for park purposes and are on each $\$ 100$ of assessed value of property. 


\section{CHAPTER VI \\ ELECTIONS AND THE BALLOT}

REFERENCES:

I. The Election Laws of Illinois, issued by the secretary of State; also by election commissioners of Chicago; also issued by county clerk.

2. The Session Laws of 1913, pp. 307-333: for 1915, pp. 393-399.

\section{Principal Election Districts.}

A. Congressional, to elect one representative for Congress. The number depends upon the population as determined by the Federal census taken every ten years. At present there are twenty-five Congressional districts, because the last General Assembly failed to reapportion the State. Nevertheless, Illinois has twenty-seven Congressmen on account of the increase in population, and the two additional are elected Nov., even years, " at large," or by the entire State, instead of by districts.

B. Fifty-one Senatorial, to elect one State senator and three State representatives for the General Assembly at Springfield.

C. Seven Judicial districts to elect one judge each for the State supreme court.

D. Eighteen circuit districts to elect three judges in each, except the eighteenth (Cook County), where twenty circuit and eighteen superior judges are now chosen. Appellate judges are appointed by the su- 
preme court from elected circuit judges, and the four appellate districts into which the State is divided are only for the purpose of holding sessions of the appellate court, assigning judges, and electing a clerk of the appellate court.

E. School districts, to elect three school directors and three trustees in country districts, or members of boards of education in villages and small cities.

F. Precincts, subdivisions of wards to provide sufficient polling places for elections in cities.

\section{Qualifications of a Legal Voter in Illinois.}

A. Citizen of the United States, either native born or naturalized.

B. At least twenty-one years old.

C. Three residence qualifications.

I. One year in the State.

2. Ninety days in the county.

3. Thirty days in the election district. In the city this means a precinct; in the country, a township; in the seventeen non-township counties, an "election precinct." These five provisions are in the State constitution and can not be changed without an amendment, in the case of the election of any constitutional officer. $^{1}$ They apply to women voters exactly the same as to men.

1 These same qualifications have generally been prescribed by the Legislature in the election of other officers whose places have been created by the Legislature. This has not always been the case, as under an agricultural drainage law of I885, "adult owners of real estate" were the only qualified electors in such drainage districts. 
Election Officers (for Chicago). Three election commissioners are appointed by the county judge for three years. The board must be bi-partisan, no more than two from the same party. The salary is $\$ 4,000$ per year. The chief clerk receives $\$ 5,000$ per year and there is an assistant chief clerk at $\$ 3,000$ per year. The real work of the board, as usual, is done by these employees. The duties of the board are to appoint all the judges and clerks of election, have charge of all printing and the distribution of the ballots, of the ballot-boxes, polling-booths, registration lists, the selection of polling-places, counting the ballots, and all work connected in any way with an election. The county judge has legal supervision over all elections. Chicago had 2,19I precincts at the elections in November, I9I6. Each precinct contains 300 voters $^{2}$ as nearly as may be, and its polling place must have one booth for each seventyfive voters. For this reason you usually find four polling booths in each polling-place. There are three judges and two clerks appointed for each precinct, paid \$5.00 (Cook County) per day for four or five days' work. (I) In the election districts in the counties, except Cook, the pay of election officers is only $\$ 3.00$ per day.

Registration (in Chicago). There are two general registration days, Saturday and Tuesday, four and three weeks before election. An amendment to the primary law adds two new registration days, one before each primary election in February and September (Session Laws, I9I3). The three judges of election in each precinct form a board of registry. Each voter must register in person at the polling place in his precinct, giving name, residence, age, nativity, citizenship in the United States, to the judges of elec-

${ }^{2}$ In country districts, there are about 400 voters to a precinct. 
tion. These registration lists are verified afterward by the two clerks of each precinct acting as canvassers. The revised lists are sent to the election commissioners in the city hall, who order the names and addresses, arranged by streets and blocks, printed. Other information obtained is kept secret, such as the ages of women voters registering!

Any voter on application can get an accurate list of all legally qualified voters in his precinct without charge. These lists are used by all the political parties through their precinct captains and election workers to check up the vote and aid in getting voters to the polls on election day.

Registration in Country Districts. Wherever the "Cities and Villages Election Act" has not been adopted, e. g., in Evanston, Blue Island, Washington Heights, the county board appoints three judges of election for each election district and each judge appoints one clerk. The three judges form the board of registry for the district and meet three weeks before the election. At this time it is their duty to make a new registration list by transferring from the poll lists of the last general election the names and addresses of all legal voters of the district and adding thereto any new names of which they have knowledge.

A voter may send by mail to the judges on registration day his name and address and that of his neighbor, if he chooses, and the judges will register such names. These lists are verified by the clerks, printed and posted in some conspicuous place where any one can consult them.

It will be noticed that registration is much more informal and less exacting in the country districts than in Chicago. The restrictions on voting, in a great city full of strangers and containing a large floating and foreign-born pop- 
ulation need to be much more severe than in a small city, or in the country where neighbors know each other well.

Primary Elections. The Illinois General Assembly passed the present primary election law at a special session in I9I0. The law was due largely to the efforts of Governor Charles S. Deneen, who called a special session of the Legislature for this purpose. A primary election allows voters to nominate directly candidates for office, and places such popular nominations under a law similar to the regular election law. The present primary law is the fourth passed. Three have been declared unconstitutional by the supreme court.

At the primary held in February, April, or September, according to the office to be filled, every voter must declare his party publicly before he is allowed to vote for the nomination of candidates for office. If he has voted for the candidate of any other party within two years preceding the primary election, or has signed a nominating petition for any independent candidate, or a candidate of another party, he can not vote at that primary. Voters must not change their minds about their party affiliations oftener than once in two years.

These are bad provisions and keep many voters away. from the primaries, where their votes are needed to nominate suitable men for office. The Illinois primary law is planned to encourage partisanship and discourage independent voting, a distinctly bad policy, that tends to destroy the good effect of a primary law. The principle of the primary law is admirable, and represents a long step in advance because the rank and file of a party now have some direct control through the primary election over the nomina- 


\section{IO4 ACTUAL GOVERNMENT IN ILLINOIS}

tions of candidates and the choice of party committees. Should any one desire to run as an independent candidate for office, he can still do so by getting a petition signed by a prescribed number of legal voters, the number of signatures depending on the office. But as long as we are not allowed non-partisan ballots at either the primaries or the regular elections, the independent candidate labors under a very great disadvantage, as he lacks the powerful aid of the organized machinery of the regular parties and the help of a party campaign fund. The chances of election of the candidate nominated by petition are exceedingly slender. Illinois has great need of a non-partisan election law that will do away with the party circle for all judicial, city, town, county, and sanitary district elections. Such a bill was defeated in the last Legislature.

Committeemen for Political Parties. The law also provides for the election of a precinct committeeman in each precinct and one member of the State central committee of each political party from each congressional district in the State. These elected committees now control the party; but the old congressional, county, and State conventions (2) are still retained to draw up platforms, discuss party management, and select delegates for the National nominating convention that selects the candidates for President and Vice-President.

The Election. Description of the Ballot. Since I891, all voting for officers in Illinois has been by ballot, and the Australian form, with the party columns and circles, is used. In counties under township organization, having town meetings, the viva voce method ("by living voice"), still prevails, as to propositions. Otherwise the Australian ballot is used. The official ballot is white: specimen ballots 
in color must be posted in conspicuous places at least five days before election to enable the voters to study them and learn the names of the various candidates for office. As there are from 300 to 400 names on the "blanket" ballots used in Cook County at the general election in November of the presidential years, it is very necessary to study the ballot beforehand if you vote intelligently. Cook County elects twenty-three (23) executive and judicial officials, thirty-eight (38) circuit and superior judges, and fifteen ( I5) county commissioners - seventy names to be placed on the ballot under each party column at each quadrennial November election. This is one of our most striking illustrations of the great need of ballot reform through a shorter ballot. Sample ballots can be secured beforehand from county clerks or city clerks.

The names of all candidates are on the same ballot, arranged under their party columns. A small square at left of each name and a circle at the left of the party name enable the voter to mark his ballot.

At the polling-place of his precinct, an election judge gives him an official ballot, after the voter has declared his name and residence, and it has been found and checked by the clerk in the registration book. The clerk must also enter the voter's name and residence on a poll list, which is afterward compared with the list of registered voters, showing exactly what percentage of qualified voters in that precinct used their voting privilege.

Marking the Ballot. The voter enters a polling-booth, where writing material is provided, and places an $\mathrm{X}$ in the party circle if he wishes to vote a straight ticket, or in the square opposite the name of every candidate for whom he desires to vote if he wishes to vote a "split" or 
"scratch" ticket. The latter is independent voting, where the voter refuses to be bound by any one party and chooses the best man nominated regardless of party. The voter is absolutely free to split his ballot at any regular election whether he has voted at the primary or not.

The voter is allowed ten minutes in the polling-booth to mark his ballot, if no one is waiting to use the booth; otherwise, only five minutes. Should a voter be crippled or blind, and unable to mark his ballot personally, then two election officers of different political parties may enter the polling-booth and mark his ballot according to his dictation. No drunken person may receive any assistance in marking his ballot.

The judge must put his own initials on the back of the ballot given the voter, and the latter must fold his ballot with those initials out before leaving the polling-booth, and must then watch the election officer drop his ballot in the ballot-box. The ballot-box must be in plain view and kept locked and never left unguarded during the election hours.

These are all legal provisions and there is a commonsense reason for every one. The great object of the Australian ballot is to secure secrecy, an honest election, and an orderly, quiet election day. Polling-places can not be in or adjoining a saloon, must be in a clean, light, respectable room on a street, instead of an alley. The use of the schoolhouses for election places is gaining favor. There is no valid reason why the people's own property should not be thus used with due regard to its primary purpose as a school. This would save thousands of dollars every election now paid for rent of polling-places and provide clean, respectable election places as well. 
The polls are open in large cities from 6. a. m. to 4 p. m.; in country districts and small cities from 7 a. $\mathrm{m}$. to $5 \mathrm{p}$. $\mathrm{m}$. Every voter is allowed two hours' absence from his work without loss of wages to vote, if he gives due notice to his employer and arranges the hours with him. All primary and election days are legal holidays for banks and government offices, but not for schools or business in general.

Elaborate "Cards of Instructions to Voters" are posted in every precinct ten days before the election and serve as a guide to the regular polling place in each precinct because one card is always posted on the door.

In Chicago, Cicero, and East St. Louis, where the election act has been adopted, an unregistered voter must lose his vote; he can not swear it in on election day. But elsewhere in the State he has this privilege if he brings a registered householder (one who owns or rents a house) as witness to his legal qualifications.

Criticisms. The principal objections to the Australian ballot as used in Illinois are (I) the required party column and circle; (2) the large number of names and the size of the sheet used, making the ballot cumbersome to handle, complicated to mark and difficult to count.

Counting the Ballots. The counting begins as soon as the polls are closed and is done by the judges and clerks of the election, who make out the tally-sheets and report the results to the county clerk, or to the election commissioners. Each party and candidate is allowed a watcher while the counting goes on to see that no mistakes are made. In spite of all precautions, there are usually protests filed with the county judge after every election, claiming a wrong count of the ballots. Then the votes must be canvassed, 
or even entirely recounted, by order of the county judge at great expense of time and money.

A Presidential Preference Vote was provided by act of the Legislature of 19r3. This provides that the name of any candidate for president be printed on the primary ballot under the name of his political party, provided a petition is presented " not more than sixty or less than thirty days before the April primary," signed by " not less than I,OOO or more than 2,000 primary electors of the party of which he is a candidate." "This vote shall be for the sole purpose of securing an expression of the sentiment and will of the party voters with respect to candidates for nomination for said office." (Session Laws, i9 3, pp. 330, 33I.) In a separate act, provision is also made for the nomination of candidates for United States senator at the April primary. The next United States senator from Illinois will be nominated at the April primaries and elected by popular vote at the general election in November I9I8. The "Little Ballot." The "little ballot" is the term applied to a bond issue, or any proposition submitted on a separate ballot to the people for their approval or rejection. This is the only form of the referendum possessed at present by the voters of Illinois. A comprehensive "I. and R." (initiative and referendum) "joint resolution" for a constitutional amendment passed the State senate but was defeated by one vote in the house in June, I9I3.

Initiative and Referendum. A true referendum also refers to the people certain laws, passed or defeated, by the General Assembly. If approved by a majority of votes cast at any general or special election, it becomes a law without the consent of the Legislature.

The initiative is the other half of the people's right to 
make laws for themselves if they can not secure a needed law from the Legislature. On a petition signed by a certain number of voters, a law considered necessary can be proposed by the people without any action on the part of the General Assembly. It may then be submitted at the next general election, passed by a referendum vote, and be placed on the statute books through the direct action of the voters.

Public Policy Law. The General Assembly in I90I passed what is known as the "public policy" or "public opinion" law. This provides that upon petition of ten per cent. of the voters of the State, any question of public policy may be submitted to the voters at any State, or general election. No more than three such questions can be submitted at any one election and they must be printed on a separate ballot, known popularly as the "little ballot." This vote of the people in no wise binds the Legislature, but is merely to serve as an index of public opinion on any important matter of public policy and to indicate what the people want. Such questions as State-wide civil service, initiative and referendum, and a corrupt practices act have received approval at the hands of Illinois voters through the public policy law. But no General Assembly has yet obeyed the desire of the voters on these important public reforms.

Voting Machines. Illinois has a Voting Machine Law, passed in 1903, whereby any city, village, or town may adopt a suitable voting machine for use in all elections except for school officers. The term "suitable machine" is defined by the board of voting-machine commissioners consisting of the governor and two mechanical experts who are to examine and pass on all machines submitted to elec- 


\section{IO ACTUAL GOVERNMENT IN ILLINOIS}

tion officers in the State. The law makes many restrictions and requirements for any recommended voting-machine. Under its authority a contract for I,O0O voting machines costing nearly one million dollars was signed by the election commissioners in Chicago in I9I I. Because of haste in letting the contract and carelessness in accepting untested machines in large numbers, there were objections by many citizens to this contract when a large appropriation was asked from the city council in part payment. A legislative investigation of the entire contract was ordered by the General Assembly and is still incomplete. The Chicago Bureau of Public Efficiency has two admirable reports on this voting-machine contract. Study these reports to find out how municipal contracts are too often let.

Criticism. The election laws issued by the election commissioners for Chicago and the same law applied to the rest of the State, issued by the secretary of state, contains several hundred pages. To this mass of material for the guidance of election officers must be added the primary law with scores of amendments. To make the situation worse, every legislature piles on amendments. Great are the difficulties confronting judges and clerks of election in applying the machinery of such a complicated law, to say nothing of the troubles of the average voter. Can an ignorant voter be taught to "split his ballot"? No wonder a majority of the voters take refuge in a cross in the party circle and therefore play into the hands of the politicians who run the party machines. A shorter, more simple ballot is imperatively demanded in the interests of good government in this State. Illinois suffers more than any other State, except New York, from a multiplicity of elective officers, and Cook County has the longest ballot, at the quadrennial November 
elections, owing to the seventy odd county officers to be selected by ballot:

The Cost of Elections. The cost of elections for Chicago and Cook County in I9I 2 nearly reached the milliondollar mark. Yet there has been an enormous increase in the cost of these elections in the last three years due to more election, primary and registration days; to increased pay for election officers in Chicago, granted by the legislature, and to the increase in the number of precincts in Chicago and in the county at large. The new women voters also add their share to this growing cost of elections; but the women are certain their votes are worth to the community all they cost. The grand total of the appropriations made by the Chicago council and the Cook County board for the elections in 1916 is the astounding sum of $\$ 1,906,-$ 405. It seems hardly credible that it needs to cost such an enormous amount for the voters of one county to register their will at the ballot box in a presidential year, even altho that county contains over one-third the population of Illinois. If the city and judicial primaries were abolished, a large saving would be effected - probably a half million dollars. Nominations for city and judicial officers should be by petition only and party columns and party names should be eliminated from judicial and municipal ballots.

The heaviest single item in election expenses is the pay of the judges and clerks. There are three judges and two clerks to a precinct, each receiving $\$ 5$ a day for his services, except in Chicago, where the pay is higher on account of the more exacting duties required of election officers and because of compulsory registration. There are now nearly 2,200 precincts in Chicago alone and the pay of judges and 
clerks for registration, primary and election days, rental of polling places, printing ballots, cartage of ballot boxes and booths, legal advertising and for all other legitimate election expenses amount to the spectacular sum of $\$ \mathrm{I}, 206,405$ for the presidential year of I9I6. There are 209 precincts in Cook County outside of Chicago and the County board has appropriated $\$ 720,000$ for the county's share of the election bills for I9I6. Some way will have to be found to reduce these huge and constantly increasing election bills.

One economy could be effected by reducing the number of elected officials, thus cutting down the size of the ballot and saving a tremendous amount of time in counting the votes for candidates - a reform greatly needed in the interest of better as well as less expensive government. Some relief can come through legislative action, but the "short cut" to all these changes and economies lies through a constitutional convention and a new constitution adapted to the needs of a great and progressing State. 


\section{CHAPTER VII}

\section{JUDICIAL TRIALS AND THE JURY SYSTEM}

REFERENCES :

I. Forman: American Republic, pp. 301-307.

2. Forman: Advanced Civics, pp. 377-384.

3. James and Sanford: Government in State and Nation, pp. 62-69.

4. Greene: Government of Illinois, pp. 146-159.

5. Winchell: Civic Manual, pp. 214-218.

6. Guitteau: Government and Politics in United States, pp. II5-127.

7. Boynton and Upton: Supplement, pp. 5I-6.

8. McCleary: Studies in Civics, ch. ii, iii, vii, and xv. (These chapters are especially valuable for high-school pupils, though not written for Illinois.)

“No man's property is safe and no man's welfare is assured where justice is denied to the poor, or where crime goes unpunished; no State can prosper where human rights are not respected."-DAvid A. WELLS.

There are two parties to every suit: The plaintiff, or complainant, the party who brings the suit, claiming he has suffered some wrong; the defendant, or person accused of having committed the wrong.

"Cases arise in two ways: Through differences in the interpretation of the law, and through its violation."

There are two kinds of cases: Criminal, where a law has been broken and therefore the plaintiff is always the State; civil, where a private right is to be protected or enforced and the resulting suit is between two persons or corporations.

Common examples of causes of civil actions are non- 


\section{II4 ACTUAL GOVERNMENT IN ILLINOIS}

fulfilment of contracts, as a failure to finish a building on time; failure to pay lawful debts, as a butcher's or tailor's bill; relations of employer and employee, as where damages are claimed because of injuries received while at work.

All criminal actions are defined by law and penalties are provided for their commission. A civil suit calls for damages in the shape of money; a criminal suit means imprisonment, or a fine, sometimes both.

\section{STEPS IN CIVIL ACTION}

I. Preliminary to the Trial.

I. Complaint, sworn to by the plaintiff before a justice of the peace, police magistrate, or judge, causing him to issue the

2. Summons. This is served on the defendant, directing him to appear in court himself, or by his attorney.

3. Pleadings: drawn up by the lawyers on both sides, stating the charge and the answer to it. Pleadings are always in writing.

4. Venires, or summons to the jurors, served if a jury is required. Frequently a jury is waived by both sides and the case is tried by the judge.

5. Subponas, or summons to witnesses, compelling them to appear at the trial to give their testimony " under penalty" should they fail to appear.

II. The Trial.

I. Opening Statement, usually made by the plaintiff's lawyer, stating the ground of action.

2. Securing a Jury. Jurors are examined as to their fitness and whether they can honestly "swear to 
try the case according to the law and evidence without prejudice or favor." Challenges are allowed both sides and are of two kinds: "For cause," and "Peremptory," without any cause given. The number of these challenges allowed depends entirely on the kind of case and is prescribed by law.

3. When the jury has been accepted and sworn in, the witnesses for the plaintiff are called first. They are put on oath, give their testimony, and are cross-examined by the attorney for the defendant. The witnesses for the defense are then questioned by the defendant's attorney and crossexamined by the plaintiff's lawyer. The evidence includes the testimony of all the witnesses and any documents, or legal papers, offered as part of the evidence.

4. Now come the arguments of the lawyers in behalf of their clients, when they review the case and present the facts brought out by the witnesses in the most favorable light for their 'client.

5. Charge to the Jury is given by the judge to instruct them in the law concerning this special case, or if an equity case, referring to the decisions of courts involving the same general principles. This is not given in a justice of the peace's court because such a petty officer is not required to be a lawyer or especially familiar with points of law.

6. The case then goes to the jury, who retire to make up their verdict, or decision. This verdict, in a civil action, states who wins the suit and recommends a certain amount of damages in addition 
to the costs of the suit, which must be borne by the loser.

7. The judgment is given by the judge in accordance with the verdict, and includes damages, the amount awarded the winning party and all costs of the suit, except lawyers' fees. Each side must pay its own lawyers. If the judgment is not satisfied within a certain time by paying it, the victorious party secures from the court an execution. This directs the forcible carrying out of the judgment by the sale of property. In Illinois $\$ 400$ worth of personal property for a married man is "exempt from execution"; \$100 worth if he is single.

Of course the loser often appeals the case to a higher court, or gets the judge to grant a new trial, so it may be years before the judgment is paid, even if it should be sustained in the higher court.

\section{CRIMINAL ACTION}

In a criminal case a complaint must be sworn to before a justice of the peace, or other judicial officer and at once a warrant for the arrest of the supposed criminal is issued and served by a constable, sheriff, or policeman, according to the court where it is obtained. The offender is brought before the court, and if the charge is a misdemeanor, or small offense, as petty larceny — stealing under ten dollars in value - or disorderly conduct, the case may be tried at once before the justice of the peace, or a municipal court. But should the charge be a felony, or "high crime," as highway robbery, and therefore a penitentiary offense, then 
the accused person by Illinois law must " await the action of a grand jury" and be indicted by majority vote of that body of twenty-three jurors before he can be tried. His case may not be reached in weeks, and even then the grand jury may find no "true bill" against him. To compel a person only suspected of crime to lie in jail under such circumstances, is unjust.

So bail is allowed, and on presenting proper sureties for his bail bond, or money pledged to assure his presence at the trial, he may be set at liberty pending the action of the grand jury. The grand jury need not wait for the State's attorney to offer the indictment against the person, but they may bring in a presentment when they know of evidence showing a person has broken some law, and may vote that a "true bill" should isue against the person. But usually the State's attorney brings in the evidence against the person accused - all the grand jury ever hears - and indictment follows if enough evidence is produced. ${ }^{1}$ (I)

For the trial a petit, or "little" trial jury of twelve unprejudiced men is necessary, and when they are sworn in, the arraignment of the prisoner follows, when the indictment is read stating the charge against him.

This is followed by his plea, or answer to the arraignment. Should he plead "guilty," and "throw himself on the mercy of the court," he usually receives a lighter sentence from the judge. But if he pleads " not guilty," then the witnesses are called and the steps in the trial are similar to those in a civil action, except a sentence - usually imprisonment - is given instead of the judgment. If the sentence is imprisonment, the prisoner is taken to the peni-

1 For comparison of a grand and petit jury in Illinois, see p. 122. 
tentiary at Joliet or Chester, ${ }^{2}$ by the sheriff, or his deputy, and begins serving his time. By good conduct after one year in prison, he may be paroled and allowed to resume his ordinary work on condition he report at regular intervals to the warden of the prison, or to an adult probation officer to whom he is assigned.

He may have an indeterminate sentence given him by the judge, and then good conduct while in prison will diminish his time by many months. He may also seek the governor's pardoning power and then his case goes first to the board of pardons for investigation and their recommendation, although the governor is not obliged to follow the recommendation.

Illinois allows capital punishment for "murder in the first degree," viz., a cold-blooded murder. "The execution of five young men in I9I 2 in Cook County jail for the atrocious murder of a truck farmer is the most recent illustration of capital punishment on a large scale in Illinois. Such wholesale execution in the name of the law has led to a growing demand that capital punishment be abolished by the Legislature. A bill to this effect failed in the last General Assembly, I9I3. Give three arguments for and against the death penalty for murder.

Penal Institutions. Illinois maintains three penal institutions for the entire State: The penitentiary at Joliet; the southern penitentiary at Chester for insane criminals; State reformatory for boys over seventeen at Pontiac. All female prisoners are kept in the women's quarters at Joliet.

The Legislature in 1903 abolished contract labor in the prisons and substituted a board of prison industries com-

${ }^{2}$ The State penitentiary at Chester is intended mainly for the criminal insane. 
posed of the commissioners of the three penal institutions. This law provides that the State may employ not more than forty per cent. of its convicts in manufacturing goods to be sold in open market, but not until all the needs of the State institutions are supplied. The convicts now make furniture, mattresses, brooms, cheap grades of clothes, shoes, wooden ware. The remaining able-bodied convicts must be employed on work for the State. There is provision under certain conditions to allow part of the money earned by a convict to be paid to his family or relatives. $\mathrm{He}$ also has an opportunity by this means to save money which will be paid him when he leaves the prison. The net profits of this convict labor for ten years are $\$ 545,000$, which has been paid into the State treasury. This sum is in addition to machinery and equipment purchased out of the profits and many thousand dollars set aside as earnings of the convicts themselves. The larger share of this prison labor is employed crushing stone to be used on the public highways. There is an immense demand for this crushed stone, which is furnished free to any township, county, or road district applying for it through the State highway commission and paying all freight charges. The railroads, however, charge such high rates that practically only towns within a. certain freight zone get the benefit of this convictmade crushed stone. Here is an opportunity for the new Public-Utilities Commission, which began work in I9I4, to help the good roads movement by compelling a juster freight rate on prison-crushed stone for road-building. There are about I,400 convicts at Joliet and about 300 each at Pontiac and Chester. A recent law provides for a new penitentiary on a farm of not less than one thousand acres, located near Joliet, and the prison at Chester is to 


\section{I20 ACTUAL GOVERNMENT IN ILLINOIS}

be moved to the same farm. Convicts are to be employed out of doors wherever possible. Illinois is certainly " moving forward" in her care of criminals. (Report of Board of Prison Industries, I9I2.)

Convict Labor. Illinois is the first State east of the Rocky Mountains to try the experiment of putting State prisoners at road-building. Colorado (2), Washington, and Oregon have been building roads with "honor convicts" for the last two years, and the system has proved of double value; the States have fine roads at a very low cost, and the convicts gain much in health and renewed self-respect because they are treated like men.

A band of forty-five convicts, put solely on their honor, were sent out in August I9I3, from Joliet, to build roads near Dixon, Illinois. They were to work as long as the weather permitted their camp to be maintained. No armed guards were with the men; they wore the clothes of common laborers, and had much freedom after working-hours. The experiment was successful and has been repeated each summer since that year.

\section{Difficulties in Law Enforcement. "Not officers} alone, but any citizen, may make a complaint against lawbreakers. But private citizens find it difficult to discover sufficient evidence upon which to make a sworn statement. It is much easier for the average citizen to let such matters alone and attend to his own private business. In the meantime, public funds may be stolen, or the public health of the community threatened, or the young people put in danger of moral corruption, all for the lack of a complaint, specific in its accusations, and supported by definite information. These reasons most frequently answer the question, "Why is not the law enforced?' At bottom, it is a question of 
public conscience. In communities where a low moral standard prevails, a few determined leaders, willing to sacrifice time, labor, and comfort for the public good, have sometimes aroused the public to action. No service to the community is more to be commended than this." 3

The Law's Delays. "Other causes of discontent with our judicial system arise in connection with court procedure. Justice is often delayed through the postponement of cases for trivial reasons. Criminal cases may drag along for months, until the public interest subsides. A wealthy litigant may secure postponements until the resources of his poorer opponent are exhausted."

Notable groups of judges and lawyers all over the country are urging the necessity of simpler and more direct court procedure. The criminal code of Illinois is no more confusing or complicated than the codes of other States, and they all need revision.

Another reason for some of our difficulties was illustrated by the recent resignation (October I, I9I3,) of the very able probate judge of Cook County because of the corrupt political influences that nominate the judges. Judge Charles S. Cutting had served Cook County as probate judge with distinguished ability for more than fourteen years, and through rival administrations - the best possible proof of his ability; - but he refused to serve out his term as he could not be given freedom to conduct the work of his court according to his own high standards of justice. His resignation was a stinging rebuke to the politicians of all parties, who control the nomination and election of our judges.

${ }^{3}$ Government in State and Nation, James and Sandford, pp. 65, 66. 
DIFFERENCES BETWEEN GRAND AND PETIT JURIES IN ILLINOIS

(Am. Rep., pp. I 52-I 53.)

Grand Jury

I. Numbers.

2. Decisions.

3. Evidence.

4. Number of Cases.

5. Kind of Cases Criminal only. Heard.

6. Sessions.

7. Term of Office.

8. Oath of Of- Grand Jurors must fice. where, three.
Always secret.

Cook County usually one month: swear never to reveal what goes on in their sessions.

\section{Petit Jury}

I2 or 6 .

Verdict; unanimous.

Both sides: plaintiff's and defendant's.

Tries only one case.

Civil and Criminal.

In open Court.

Indefinite: until case ends.

Petit Jurors swear, " to try the case according to the law and evidence without prejudice or favor."

\section{SEVEN IMPORTANT WRITS}

A. "The writ of Habeas Corpus is addressed by a judge to one who holds another in alleged unlawful custody, directing him to produce the person in court and show why he detains such person."

a. Meaning of words: "Bring you," or "produce you," the body: literally, "that you may bring the body."

b. History of writ. Gained first in England, reign of Charles II, I679. 
c. May be suspended in time of war only by order of Congress. If Congress so directs, President may suspend the writ. (See action of Lincoln, $\mathrm{I} 86 \mathrm{I}$, in Baltimore; also action of McKinley, I898, Spanish-American War.)

B. Injunction is an order from a judge, or court, to a lower court, individual, or corporation, restraining them from doing a certain thing. Illustration: Injunction granted against strikers to prevent injury to property of corporation where strike is in progress.

C. Mandamus, "we command," is an order from a judge, or court, to another court, individual, or corporation, commanding them to do a certain thing. Illustration: Writ of mandamus could be obtained ordering a street-car company to remove tracks illegally placed.

D. Writ of Quo Warranto ("by what authority?") is an order from a judge to a lower court, individual, or corporation, to show their reasons for doing a certain thing. Illustration: If it is claimed an officer has not the legal qualifications required, any tax-payer could bring suit under the writ of quo warranto to test the office-holder's right to his office.

E. Writ of Certiorari, or "to be certified," is an order from a higher court to a lower court to send up certain papers required by the higher court. This writ prevents the lower court from blocking the actions on an appealed case in a higher court by refusing to send up important documents needed in the case. 


\section{I24 ACTUAL GOVERNMENT IN ILLINOIS}

F. Writ of Attachment is an order to seize property in payment of a debt.

G. Writ of Replevin is an order to recover goods alleged to be wrongfully taken or detained. Security must be given to hold the goods pending a suit to decide ownership; if this goes against the plaintiff, he promises to restore the goods.

These writs are referred to so often that even a layman needs to know something about them, although the definitions given would not satisfy a lawyer. The Statutes provide when and how they may be obtained and the services of an attorney would be required to interpret the law in such a matter. The last two writs may be issued by a justice of the peace and a police magistrate, but the first five can only be obtained from a judge and a court of record.

\section{PERTINENT QUESTIONS}

I. If some one owed you $\$ 50$ and refused to pay, in what court could you sue him? If he owed you $\$ 250$ ? If the suit involved $\$ 1,000$ ? If $\$ 5,000$ ?

2. May a person's acts be inquired into by the grand jury without his knowing anything about it? May grand jurors reveal the proceedings of the jury? Why?

3. Are lawyers officers of the court? What oath does each lawyer take when admitted to the bar?

4. What is meant by "change of venue"?

5. What things are "exempt from execution" in Illinois?

6. Can a civil suit proceed in the absence of the defendant? A criminal suit?

7. Why are there at least two justices in every town?

8. Are they county, town, or city officers?

9. Define " docket," "summons," "warrant," "subpoena,' ' venire," "costs," " recognizance." 


\section{JUDICIAL TRIALS AND JURY SYSTEM I25}

10. What are the similarities in a criminal and civil suit? What are the principal differences in procedure?

II. What is the difference between a warrant and summons? Sentence and judgment? Plea and pleadings? Arraignment and opening statement?

12. Debate one of these questions:

A. Resolved, That the grand jury ought to be abolished.

B. Resolved, That capital punishment is not justifiable. 


\section{CHAPTER VIII}

THE STATE OF ILLINOIS: PHYSIOGRAPHY AND HISTORY

Physical Features. Illinois, the "Prairie State," lies about the middle of the great central plain that extends from the Arctic to the Gulf and from the Alleghenies to the Rockies. Its highest point, Charles Mound in Jo Daviess County on the Wisconsin line, is about $\mathrm{I}, 300$ feet above sea level; the lowest point at Cairo is only 300 feet in altitude.

Latitude. Illinois lies between parallels $37^{\circ}$ and $42^{\circ} 30^{\prime}$ north latitude. Three hundred and eighty-five miles in length, two hundred and eighteen miles in width are its extreme dimensions. Extend these eastward on a map of the United States and observe that our southern parallel would strike Old Point Comfort and Hampton Roads, Virginia, and our northern parallel would touch Boston. If Chicago dwellers could imagine Madison Street extended due east three thousand miles it would strike the Old Roman Forum, and yet no one thinks of Rome and Chicago on the same parallel of latitude.

Area. The area of the State has been quite accurately determined as 56,650 square miles in spite of the difficulties in surveying two such irregular boundary lines as the erratic curves of the Mississippi and Ohio rivers.

Impress these facts about your State on your memory and use them frequently for comparison with other States and foreign countries. 
Surface. Illinois is debtor for its rich soil and level surface to the grinding, carrying power of the great ice sheet of the glacial epoch. Only two small areas in the State, one in the extreme south and one in the northwest, fail to reveal this glacial action, and the fertile prairie soil of Illinois is the product of the crushing, grinding power of this slow-moving ice-sheet thousands of years ago. The rich, level, well-watered surface thus produced has predestined Illinois for an agricultural State, and in fulfilment of its mission the farmers form more than half the population.

Waterways. No State in the Union has a more magnificent system of waterways than Illinois. The Mississippi borders the State for 550 miles measured by its curving boundary lire; the Ohio and Wabash furnish nearly 300 miles of water frontage in addition, while Lake Michigan provides 60 miles of water frontage on the northeastern shore. We still make little use of these natural waterways in comparison with foreign countries like France and Germany, where cities and provinces have spent millions on the development of inland harbors, quays, wharves, and freight-handling facilities. Illinois is just waking up to the value of her river- and lake-heritage.

Forests. We have abundant proof that Illinois once possessed fine forests, in spite of her present reputation for open prairies. Witness the many saw-mills, the homemade furniture in the pioneer houses, the miles of rail fences and the log cabins of the early settlers. An exhibit of woods from Illinois displayed at the World's Fair in I893 showed seventy-five species of native trees. The most common are oak, maple, elm, black walnut, hickory, ash, birch, chestnut, and cottonwood. 


\section{I28 ACTUAL GOVERNMENT IN ILLINOIS}

Coal. It is a surprise to find coal, lead, building stone, petroleum, various commercial clays, and even iron, hidden under the surface of a prairie State. Illinois ranks second in the Union in the production of bituminous coal. Nearly two-thirds of the State is underlaid with an excellent quality of soft coal, and the coal-mining industry is one of the leading occupations. (Notice the large number of laws to regulate the mining of coal and to protect the miners.)

Indians of Illinois. The most important group of Indians was the confederacy of the Illini, made up of various tribes like Michigamies, Peorias, and Kaskaskias. Through other parts of the State roamed the Shawnees, Sacs and Foxes, Pottowattamies, and Miamis, who have left their names on many geographical features of the Middle West.

Indian Relics. Indian mounds are scattered over the State. Pottery, cloth, copper ornaments, have been found in these mounds. In Cook County along the lake shore, from Evanston northward, are remains of various "chipping stations" that show there were famous arrow-makers among the Pottowattamies. These piles of stone chips along the lake shore mark the places of manufacture and exchange for the famous arrow-heads of this tribe, and arrows tipped with this noted product of the Indian artisan have been found as far west as the Dakotas, showing how widely dispersed was the trade in Illinois wares - a foreshadowing of the commercial greatness of the State.

Meaning of Illinois. The name of our State is the best proof that the Illinois Confederacy had the most to do with the early settlements on the Illinois and the Kaskaskia rivers. "Illini," "real men," answered the Indian 
warriors, when Father Hennepin asked who the tall, straight braves then in camp were.

History of Illinois. As far as we have any record, two Frenchmen, in 1673 , a fur trader, Louis Joliet, and a Jesuit priest, Father Marquette, were the first white men of European blood to discover and explore the Illinois country. Seven years later came LaSalle and his faithful captain and friend Tonty, "the man with the iron hand," the Indians named him. The two forts built by these soldiers of fortune, Fort Crevecœur at Peoria and Fort St. Louis on the famous Starved Rock near Utica, were the first attempts to take military possession of the Illinois country. The name Starved Rock was given nearly a hundred years after Tonty's day, when the conquering Iroquois starved out the Pottowattamies and the Illinois, about I769.

Five French Villages. Probably as early as I725 five permanent French villages, Cahokia, Kaskaskia, New Chartres, Prairie du Rocher, and St. Phillipe, had been established in the American Bottom along the Mississippi and Kaskaskia rivers. The Treaty of Paris closing the French and Indian War in 1763 , transferred the Illinois country to Great Britain. So the lilies of France had to yield to the Union Jack of England in the great Indian country of the Middle West. Nearly one-third of the French inhabitants left their villages, taking their personal property and slaves with them.

Colonel George Rogers Clark. The capture of Kaskaskia and Vincennes by Colonel Clark and his little band of "long knives" after their terrible winter march in I778I779 resulted in transferring the Illinois country to its third flag. Colonel Clark's expedition gave the American 


\section{I30 ACTUAL GOVERNMENT IN ILLINOIS}

envoys in Paris at the close of the Revolution courage to insist that since United States soldiers were already in possession of the great Northwest Territory, it must remain part of the new nation, and England very reluctantly surrendered the territory between the Great Lakes, the Mississippi, and the Ohio.

Ordinance of I787. Almost the last act of the Congress under the Articles of Confederation - our first, and unsuccessful, experiment in a national government - was to organize the Northwest Territory under the provisions of the famous Ordinance of 1787 , which provided the first permanent government the Illinois country had enjoyed since Colonel John Todd, the county lieutenant commissioned by Governor Patrick Henry to rule the "county of Illinois, Virginia," had gone back to his native state and left Illinois affairs in confusion. ${ }^{1}$

Illinois under Territorial Government. Illinois has been governed as a part of three separate territories: Northwest Territory, I 787-I800; (2) Territory of Indiana - I800-I809- which included Illinois, Michigan, Ohio, and Indiana (the capital was Vincennes); (3) Territory of Illinois - I809-1818 - including Illinois, Wisconsin, and Northern Michigan (the capital was Kaskaskia). The admission of Ohio ( 1803 ) and Indiana ( 1816 ) into the Union as States; the desire for more convenient land offices and better opportunity to secure claims in the rich government lands being rapidly thrown open for settlement were the principal reasons the United States organized the Indiana and Illinois territories.

Fort Dearborn. When the United States Government built Fort Dearborn at Chicago in the winter of $1803-04$,

${ }^{1}$ Smith: Hist. Ill., ch. xiv-xv. 
its blockhouses and stockade marked the most western outpost of the Federai Government, and its building in the far wilderness was ridiculed in Congress as a piece of national folly. The massacre at Fort Dearborn in I8I2 occurred during the second war with England, and was the only noteworthy event of that war in the far West except Hull's surrender at Detroit.

Illinois a State. Illinois was admitted to the Union December 3, 1818, and President Monroe issued the proclamation announcing the fact to the people of the United States.

Northern Boundary of Illinois. In the famous Ordi-

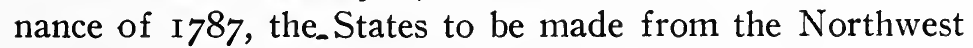
Territory were to be divided by a line running through the south end of Lake Michigan. While the Enabling Act to permit Illinois to become a State was under discussion in Congress, April, I8I8, our territorial delegate, Judge Nathaniel Pope, moved to amend the bill by striking out the section about boundaries and substituting parallel $42^{\circ}$ $30^{\prime}$ for the northern boundary. Judge Pope took advantage of the strong feeling in Congress over the slavery question caused by the debate over the Missouri Compromise. Fear that slavery interests might finally control the new State, if its only entrance by water should be the Ohio and Mississippi rivers, led Congress to adopt the amendment and make Illinois' northern boundary line parallel $42^{\circ} 30^{\prime}$.

"The result was to give Illinois a strip of country sixtyone miles wide extending from the lake to the Mississippi and including the present fourteen northern counties, with a combined area of 8,500 square miles of fertile country. It includes sixty-one miles of lake-shore line and the sites 
of the cities of Chicago, Evanston, Waukegan, Elgin, Aurora, Rockport, and Galena." 2

"No one ever rendered Illinois a more important service in Congress than did Pope. Had the northern tier of counties included within the sixty-one-mile strip become attached to Wisconsin, Illinois would have lacked an important element in her Legislature at the outbreak of the Civil War, an element Wisconsin did not require because Union sentiment in that State was always very strong. The commanding position occupied by Illinois during the Civil War, with one of its citizens in the Presidential chair, and another leading the armies of the Union, including Illinois' two hundred and fifty thousand citizen soldiery, illustrates the sound judgment of Pope."

The Constitutions of Illinois - Principal Points:

A. Under the Constitution of 1818 :

a. Most State officers elected by the Legislature.

b. No veto power for the governor.

c. Judges chosen for life.

d. Council of Revision, composed of governor and judges, revised laws passed by Legislature, and were thus a substitute for the veto power.

Power was vested in the Legislature.

B. Under the Constitution of 1848 :

a. Officers elected by the people. Council of Revision abolished.

2 Currey's Hist. Chicago, Vol. I, pp. II7-I19.

NoTE.- " By the Ordinance of 1787 , Chicago belongs to Wisconsin."Hon. J. R. Doolittle, speech at opening of Sanitary Canal, January I900. 


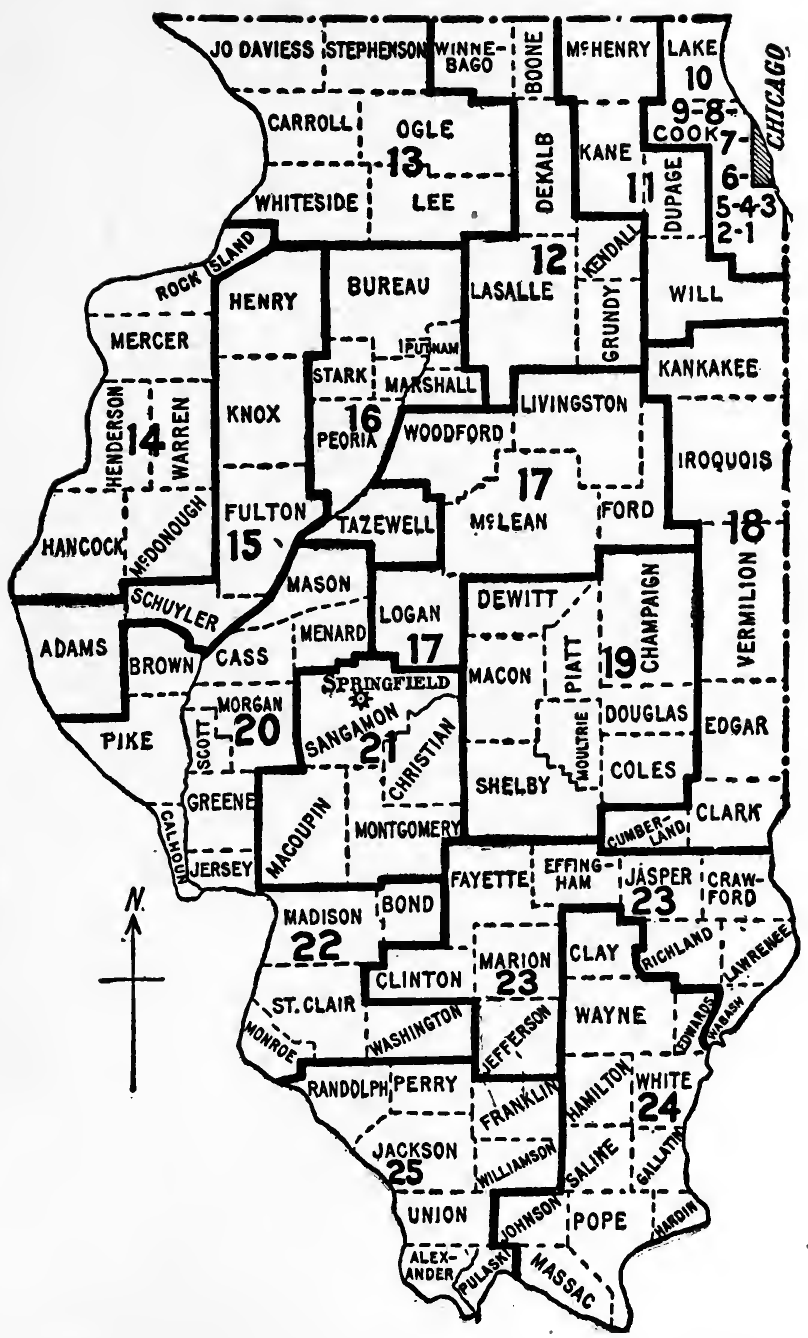

Map of Illinois, Showing the Congressional Districts 


\section{I34 ACTUAL GOVERNMENT IN ILLINOIS}

b. Judges elected for definite terms (nine and six years).

c. Power of Legislature to contract State debt limited to $\$ 50,000$ unless people by popular vote consented.

d. Sinking fund to pay bonds was created by a twomill tax. Power of Legislature much limited: due to a $\$ 14,000,000$ debt created by former Legislatures owing to their craze for "internal improvements," like railroads and canals. This debt was paid, principal and interest, about I87 I - the year of the Chicago fire - and citizens of Illinois have a right to much pride in the fact that their State has never failed to pay its honest debts.

C. Under the present Constitution of 1870 . (For details, see legislative, executive, and judicial departments of the State, chapters ix, $x$, and $x i$.)

Capitals of Illinois. Kaskaskia remained the capital for two years. A request was made that Congress grant four sections of land - 2,560 acres - for the site of a town to remain the capital of Illinois for twenty years. Congress at once granted the land and the second capital was built near the headwaters of the Kaskaskia river, and named Vandalia.

The "Long Nine." When the Legislature met in 1836 the State was much excited over the question of internal improvements. A bill was introduced carrying appropriations for $\$ \mathrm{IO}, 200,000$, to build railroads, public roads, and canals throughout the State. This same Legislature was to locate a new capital, so much log-rolling was the result. The "long nine" from Sangamon County, two State Senators and seven representatives, included Abraham Lin- 
coln among the delegation. The combined height of the men was just fifty-four feet, and they organized a club known as the "Long Nine." Through the shrewd trading of votes on internal improvements eagerly desired, the Sangamon County club succeeded in landing the coveted prize, and Springfield, then a village of 1,500 people, became the capital.

The year I 837 also saw the failure of many State banks through inability to redeem the wild-cat currency they had issued so recklessly. The Lovejoy press riots at Alton, caused by Mr. Lovejoy's attempt to print an anti-slavery paper in Illinois, resulted in the murder of the editor and owner of the paper by the mob. This murder occurred in 1837 .

Of all the railroads, canals, and public roads started through the immense sums voted by the State Legislature, not one was a success except the Illinois and Michigan Canal, which was opened for traffic in 1848 . The canal has paid for itself several times over in tolls received and turned a handsome sum into the State treasury as well. Should it be filled up now, as suggested, and the land thus made sold, the State would be the richer by millions of dollars. Such a project to sell the canal would require a referendum vote of the people.

Slavery. There were several attempts to make Illinois a slave-holding State. The most exciting, bitterly contested campaign over the question was fought in 1824 when the friends of freedom gained a decided victory by defeating a proposition for a new, pro-slavery constitution. Governor Edward Coles was the leader of the forces of freedom and contributed his entire salary of $\$ 4,000$ to the campaign fund. Governor Coles had an able assistant in 


\section{I36 ACTUAL GOVERNMENT IN ILLINOIS}

Congressman Daniel P. Cook, who stumped the southern part of the State in behalf of freedom.

The Black Hawk War in 1832 resulted in the United States Government removing all Indians from Illinois and giving them lands west of the Mississippi.

The Mormons settled at Nauvoo, and after six years of stormy occupation voluntarily crossed the Mississippi river and moved across the plains to Utah Territory, then a part of Mexico.

The Lincoln-Douglas debates; the nomination of Lincoln (I860) in the Lake Street Wigwam, Chicago; Illinois' honorable record in the Civil War for numbers of troops sent to the front $(250,000)$; four famous leaders and statesmen, Lincoln, Grant, Logan, Richard Yates, the war governor and the "soldiers' friend"; the noted composer of war songs, George F. Root, and the wonderful singers of those songs, the Lumbard brothers, who sang to civilians and soldiers by the thousands on street corners, in the camps, at great mass meetings of citizens; the Chicago fire; the Haymarket riots; the Columbian Exposition - all these topics are of much historical importance for Illinois, but do not come within the range of the title of this book.

Pullman Strikes. The Pullman railroad strikes of I894 involve a civic question and need mention on that account. President Grover Cleveland and John P. Altgeld, governor of Illinois, had a sharp controversy over the right of the President of the United States to send Federal troops into a State when the governor of that State had not requested them. President Cleveland ordered the regulars from Fort Sheridan into Chicago to protect the United States mails and carry out the orders of a Federal judge whose injunctions against the riotous strikers had not been obeyed. 
The governor claimed the State militia could handle the situation. But quiet was not restored until the regulars had marched into the city and later the Supreme Court of the United States sustained President Cleveland's action.

General References for History of Illinois.

I. G. W. Smith: Students' History of Illinois, 1907.

2. Mather: The Making of Illinois.

3. Greene: Government of Illinois, ch. i, ii, iii.

4. Randall Parrish: Historic Illinois.

5. Campbell: Illinois History Stories. (Helpful for older pupils, although intended for eighth grade.)

6. J. S. Currey: History of Chicago, 1912. (Very valuable for entire State.)

7. Osman: Starved Rock (IgII).

8. Catherwood: Story of Tonti. (Fiction; to be used with caution.)

9. Kinzie: Wauban-Fort Dearborn Massacre.

Io. Parrish: When Wilderness was King.

II. E. P. Roe: Barriers Burned Away. (Chicago Fire.)

12. Churchill: The Crossing. (Colonel Clark's expedition.)

13. Carr: The Illini.

I4. Publications Illinois Historical Society, Springfield. (List sent on application. One dollar will enroll any school on their mailing list and furnish all their reports and monographs.) 


\section{CHAPTER IX \\ THE GENERAL ASSEMBLY}

REFERENCES :

I. Forman: American Republic, pp. I35-I44.

2. Forman: Adz'anced Civics, pp. I62-167.

3. Garner: Government in United States, Supplement, I915, pp. 4-17.

4. Greene: Government of Illinois, pp. 76-85.

The Legislature of Illinois is called the General Assembly and meets in Springfield in the capitol biennially, the first Wednesday after the first Monday in January of the odd years. The governor may call an extra session any time. The General Assembly is bicameral, having a Senate of fifty-one members and a House of Representatives of one hundred and fifty-three members - a Legislature of two hundred and four.

Apportionment. The legislators are apportioned among the fifty-one senatorial districts. One senator and three representatives are elected from each district in November of the even years. Senaiors from the even-numbered districts are elected at one November election and the senators from the odd numbered districts at the next biennial election. The entire one hundred and fifty-three representatives are elected every two years. In consequence, the house must reorganize every regular session.

The senatorial districts are determined by population, and the Legislature reapportions the State every ten years according to the new Federal census. (I) Cook County has 
nineteen senatorial districts and seventy-six votes in the General Assembly. Minority representation, or "cumulative voting," is allowed only in electing State representatives.

Minority Representation. Minority representation is the unique feature in the Constitution of I870. Every voter has three votes for State representative. ${ }^{1}$ He may divide them as he likes: one to each of three; one and a half to each of two men; or he may. "plump" his three votes on one man, thus assuring his election. This gives representation to a party in the minority and when adopted was hailed as a notable reform. After forty years' service, it works out in this way: The leaders of the two older parties agree to nominate two candidates, or one, in each district, according to their relative strength in each of the fifty-one senatorial districts. Then by this ingenious device of the voter massing his three votes on their one candidate, the party in the minority throughout the State is sure of electing one-third the representatives. The situation is somewhat complicated by the entrance of a third party: yet three large parties instead of two only make it easier for a small group of voters by "plumping" to defeat the divided strength of their enemies and elect their candidate, who is often entirely unfit to represent the district. Mi-

${ }^{1}$ For a few years this method of "cumulative voting" was tried in electing trustees of sanitary, or drainage, districts, in the State. But that section of the Drainage Act was soon repealed, and now minority representation is limited to State representatives. (Rev. Stat., ch. xlii, sec. 217.) There is provision, however, for cities to use minority representation in the council by electing three aldermen from a ward and applying cumulative voting, if any city chooses to adopt this method. But the law seems to be a dead letter at present. (Rev. Stat., ch. xxiv, secs. 53-54. In force July, I9II.) 
nority representation in its present form ought to be cast out of the constitution and the unvarying principle, "one man, one vote," substituted.

Qualifications. Both senators and representatives must be citizens of the United States and have lived in the State five years and in their districts two years before election; but senators must be twenty-five years old, while representatives are only required to be twenty-one. Senators' term is four years and representatives' two. Each is eligible for reëlection.

Disqualifications. No one can legally be a member of either house if he has ever been convicted of bribery, perjury, or any other crime; neither is he eligible if, having held public funds, he has failed satisfactorily to account for them. He can not hold any other profitable State or Federal office at the same time he is a member of the Legislature.

Each member, before he can take his seat, must " declare on oath that he has not given any bribe to secure his election and that he will accept no bribe during his term of office." (Constit., Art. IV, sec 5.) Any member who refuses to take this oath, or is guilty of perjury in taking it, thereby forfeits his seat. All such questions as the right of any member to his seat are decided by each house for its own members. It takes a two-thirds vote to expel a member. The expulsion of Frank D. Comerford, second senatorial district, by the House of Representatives, in I905, illustrates this point. Comerford charged wholesale corruption in the Legislature of 1905 in a speech made in Chicago, and given wide publicity through the daily press. A special committee in the House investigated the charges and recommended Comerford be expelled. This was done 
in February by a vote of I2 I yeas to I 3 nays, being more than the required two-thirds vote. $\mathrm{He}$ was reëlected by his district at a special election called by the governor April 4, 1905, was sworn in a second time and served out his term. (See Journal House of Representatives for 1905.)

By all these devices Illinois has tried to keep her Legislature pure; but she has not succeeded very well, as the General Assembly has not had a good reputation for most sessions. The members, however, represent the will of the active voters in their districts - the stay-at-home voter does aot count - and therefore the Legislature is fully up to the average intelligence and morality of the voters in the State.

Salary. Senators and representatives are paid $\$ 3,500$ per session (2) and ten cents mileage for necessary travel in going and returning from Springfield; also an allowance of $\$ 50$ for newspapers and stationery. Do they have the "franking privilege" like members of Congress?

Organization. The lieutenant-governor is president ex-officio of the Senate, but has no vote except in case of a tie. The senators choose one of their number for president pro tem to preside in the absence of the lieutenantgovernor. The speaker is chosen by the representatives from their own number. Where the majority party is split into factions, or there is a third party in the House, as there has been most sessions since 1870 , prohibitionists, socialists, labor party men, or progressives, the struggle to elect a speaker may consume weeks. The regular session of the 48th General Assembly did not organize for three weeks (from January 8 to 29, I9I3) (3), when the speakership deadlock was broken by the election of William McKinley (Dem.), from Lake View, Chicago, as speaker. 
The unusual selection of two United States senators to succeed Shelby M. Cullom, whose term expired March 4, I9I3, and William Lorimer, whose seat had been declared vacant by the United States Senate, was the cause of the deadlock. The election of J. Hamilton Lewis (Dem.) for the six-year term and Lawrence Y. Sherman for the short two-year term, March 26, through the Democratic-Republican combination, broke a second lengthy deadlock. (4) These are the last two senators to be elected by the General Assembly. (See Amendment XVII, U. S. Con.)

Powers of the Speaker. The speaker of the House has large power through his appointment of all committees, including the naming of the chairmen. He also has the power of recognizing or ignoring a member who desires to address the House, according as he favors or disapproves of his motion. This is known as the power of recognition. He declares the result of every vote, and unless the yeas and nays are recorded in a roll call, the speaker may announce a motion carried which his party favors, when a roll call would show it defeated. This is "gavel rule," because the fall of the speaker's gavel as he announces the vote, legally closes it, and has often been used to " railroad through" bad bills and defeat good ones. If the lieutenant-governor and the president of the senate are unable to act as governor, the speaker assumes the office for the remainder of the term.

Employees. Each house chooses clerks, postmasters, sergeants-at-arms, doorkeepers, and a horde of lesser employees, such as watchmen, janitors, messengers, stenographers, secretaries to the members, "clock-winders, and transom-openers," the number chosen depending very largely on the size of the throng of hungry politicians 
clamoring for jobs as rewards for political services rendered at the previous November election. The corridors of the capitol are crowded with this army of needless employees. (5)

Sessions. The Illinois General Assembly has the very bad habit of generally meeting only on Tuesday, Wednesday, and Thursday each week, and practically little work is done before the middle of April. They usually adjourn early in June, and thus a session of five months means only six weeks or two months of actual law-making. In the meantime the State is paying all legislative employees for full-time work. The bad custom of permitting members of the Legislature to accept railroad passes was largely to blame for these short weekly sessions, but an anti-pass bill was killed in the legislature many times. The present ruling is an unforeseen result of the Public Utilities law passed in I9I3. (6)

Committees. The real work of the two houses is done in standing committees, numbering from three to twenty-five members. Each is assigned to one or more committees. In the Senate these committees are elected after being nominated in party caucuses. A party-caucus is a meeting, usually secret, of the members of a political party in House or Senate, to determine committee membership, or how the party members shall vote on important bills. If the party leaders are able men, they hold their party members rigorously to the policy agreed on in the caucus.

In the House the speaker names the members of the committees. If he is slow in announcing these committees, as in the 48th Assembly, I9I3 (not all selected until the last of April), the House falls below the Senate in its work.

The principal committees are those on appropriations, judiciary, elections, agriculture, education, railroads, rev- 
enue, waterways, charitable and reformatory institutions. The Senate has about forty standing committees; the House, about seventy.

Rules of Procedure. Each house adopts its own rules of procedure. The rules of the House have been in use many years and are well adapted to allow the party in the majority to ride rough-shod over the minority. A small beginning was made in the Legislature of I9I3 to alter these ancient rules; but any genuine reform was defeated by the house machines. (7) It takes an actual majority of all the members elected in either house to pass a bill on its final, or third reading: seventy-seven votes in the House and twenty-six in the Senate is the constitutional number.

Work of Legislature. The following are the principal things the General Assembly may do through its lawrilaking power, although the number of laws passed is legion:

I. Raise and collect a revenue by direct taxation.

2. Raise and maintain a militia.

3. Create and maintain a public-school system.

4. Provide for higher education, as a State university, normal and high schools.

5. Care for defectives, as the insane, blind, deaf and dumb, paupers, and epileptics.

6. Detect and punish crime.

7. Maintain a system of public roads.

8. Charter corporations, as railroads, banks, insurance companies, clubs, etc.

9. Create and control local governments, as counties, cities, villages, school districts, towns, sanitary and drainage districts. 
Io. Determine conditions of the suffrage and make all election laws.

How a Bill Becomes a Law. Bills may originate in either house, and any member of the General Assembly may introduce a bill. This is done when the roll is called on certain days early in the session and members respond by reading their bills by title. For most bills the process of being turned into law resembles an obstacle, or "hurdle race." The first difficulty encountered is the committee to which it is referred by the speaker, if introduced in the House. When a bill is introduced in the Senate, the senator responsible usually requests that it be referred to a certain committee, of course one he thinks favorable to his bill. The committee has power to cut the bill to pieces, or amend it, so that even the author would not recognize his own bill. If hostile to the bill, the committee may " pigeonhole" it, "lay it on the table," and fail to report it out of committee. However, if the member introducing it is actually interested in its passage, he may, by his persistent inquiries about the bill, make the chairman of the committee "holding it up" so uncomfortable that the committee may report it out "without any recommendation,"equivalent to disapproval of the bill - or with the "recommendation that it do not pass"- a far worse fate for the bill. The committees are justly named "legislative graveyards."

The time allowed for debate on a bill is determined by the days left in the session and the number of bills to be considered. In the hurried closing hours of the last day, generally a day-and-night session, scores of bills, advanced to third reading, are rushed through without debate, and 


\section{I46 ACTUAL GOVERNMENT IN ILLINOIS}

when many members have no idea what they are voting on. Hundreds of good bills also fail through lack of time to vote on them in the crowded closing session. The final vote is always by roll call, when the "ayes and nays" are recorded in the journal. This gives excellent opportunity for the voters in each district to learn how their members voted on important bills.

The Legislative Voters' League issues very interesting bulletins each week of the session of the General Assembly. These bulletins report what is done and how each member votes, or " passes," at every roll-call. They are the best way to keep track of your State representatives and senator. Any one can get the bulletin by addressing the secretary of the League at Chicago, or Springfield, and enclosing postage. For a humorous account of the sessions of the 48th General Assembly (I9I3), see the letters of George Fitch, member from Peoria, in the Chicago Tribune, Sunday edition, January to June, I9I3. These letters are well worth reading as the first impressions of a new member who went to the Legislature anxious to serve his district well, but found himself helpless under the rules of procedure under which the House works.

Some members dislike the publicity of a roll-call so much? they refuse to vote rather than be recorded on certain bills. What of the courage, or convictions, of such a dodging legislator?

All bills must be read on three different days; on two days usually by title only, but the title of a bill must tell plainly what it is about. Amendments can not be added after a second reading, unless by unanimous consent of the members present, or by sending it back to the committee. The bill is ordered printed after second reading with the 
amendments, and a copy is placed on the desk of each member.

Lobbying, or the efforts of interested persons not legislators, on behalf of a bill, is a common practice. Many powerful corporations maintain paid lobbyists at Springfield through every session to work for or against certain bills. Log-rolling, or the exchange of votes between legislators, is another common practice. "I will vote for your bill if you will vote for mine."

The Enacting Clause. One way the enemies of a bill may kill it is to "move to strike out the enacting clause." If this motion prevails, the bill is doomed. No bill can become law unless it is prefaced by the words, " Be it enacted by the People of the State of Illinois, represented in the General Assembly."

The Veto Power. After passing both houses and being signed by both presiding officers, the bill is sent to the governor. He may keep it ten days, holidays and Sundays excepted. If he fails to return it at the end of this period, it becomes a law without his signature. If he approves the bill he signs it; the secretary of State affixes the great seal of Illinois, and attends to its publication. The bill is now a law, and goes into effect July I, unless some emergency exists and the law goes into effect at once. Emergency matters must have a two-thirds vote for immediate enforcement. (Constit., Art. IV. sec. I3.)

But should the governor disapprove, he returns the bill, with his objections, to the house where it started; it must then receive a two-thirds vote in each house to pass it over the veto and make the bill law without the governor's signature. Should the General Assembly have adjourned, then the governor files the bill with his objections with the 
secretary of State and the bill fails to become law, at least until the next session of the Legislature.

The Selective Veto. The governor of Illinois may veto any item in an appropriation bill and allow the rest of the bill to become law. This is a valuable aid in preventing extravagant or unwise items slipping into an appropriation bill. All appropriation bills are required to state the amount of each item and its purpose. This is to protect the governor's selective veto and to guard against extravagant expenditure.

Legislature of I9I3. A quotation from "Bulletin No. 2I, Legislative Voters' League of the State of Illinois," the last issue for the 48th General Assembly, follows: "Adjournment of the 48th General Assembly, the most remarkable session of a State Legislature in the history of Illinois, in many respects, came at five o'clock this morning - June 2I - when Speaker McKinley let fall the House gavel for the last time. Fifty Senate bills (passed by the Senate) ready for final action were swept into the discard. Of the I, 6 I 7 bills introduced in both houses only 240 ran the legislative gauntlet and reached the governor's desk for signature. The final week of the State's longest legislative session - from January 8 to June $2 \mathrm{I}$ - was one of feverish activity. From morning to midnight each day of this final week, members fought to have advanced and passed the hundreds of bills that had piled up during the months of inactivity. Most of them failed, and during the last three days, hundreds of measures, important and unimportant alike, were lost. The most important measures which passed both houses include: Woman's Suffrage, State Public Utilities Commission, Municipal Ownership of Public Utilities, Consolidation State Fish and Game Departments, 
State Epileptic Colony Appropriation, Good Roads, Primary Law Amendments, Workmen's Compensation Act, Legislative Reference Bureau, Chicago Municipal Court Act, Chicago Outer Harbor.

"Members declined to enact an anti-railroad pass law unless it had for a companion measure a salary boost for legislators (from $\$ 2,000$ to $\$ 3,500$ ). The senate refused to concur in what some of the members styled a legislative bribery proceeding, and killed the salary raise bill after it had passed the bill forbidding passes. The House promptly responded by sending the anti-pass bill to legislative limbo." (8)

One senator remarked, "This Assembly ought to do its work in ninety days! If the Legislature would adjourn for five years, the State would be better off." This quotation illustrates from the proceedings in a recent session of the Legislature several points mentioned in this chapter. Practical, recent illustrations of actual government in Illinois are always desirable. (9)

Comparison of Congress and General Assembly of Illinois. [Fill out this outline.]

General Assembly.

Congress.

I. Legal Name.

2. Time and Place of Meeting.
A. Senate.
B. House.

3. Composition.

A. Senators.

B. Representatives.

4. Qualifications. 


\section{General Assembly.}

Congress.
A. Senator.
B. Representative.

5. Term of Ofifice.

6. Time of Election.

7. Presiding Officer.

8. Sole Powers.

9. Salary.

\section{PERTINENT QUESTIONS}

I. What is the organization in Illinois for studying the records of members of the General Assembly and for securing the election of honest, efficient legislators?

2. Why are the November legislative elections of such importance to every citizen of Illinois?

3. Why does our General Assembly fail to pass laws demanded by the people?

4. Is there a legislative bureau in Illinois to collect information for the benefit of members, or to assist them in the preparation of bills?

5. How is a bill introduced in both houses?

6. Why is minority representation a bad thing?

7. What is the penalty for accepting a bribe?

8. What are the arguments against increasing the salary of an Illinois legislator?

9. Give all possible ways a bill may fail.

Io. Give the quickest method by which it may pass.

II. How can the speaker help pass a bad bill?

12. Why are committees called "legislative graveyards"?

13. What is a senatorial district? How many has Illinois?

I4. What is "gavel rule"? Lobbying? Log-rolling?

15. What is "railroading" a bill? 


\section{CHAPTER $\mathrm{X}$}

\section{EXECUTIVE}

\section{REFERENCES :}

I. State Constitution, Art. v.

2. Forman: American Republic, ch. xx; Adv. Civics, ch. xxiii.

3. Greene: Government of Illinois, pp. 85-90.

4. Garner: Government in the United States, ch. v; Supplement, Government Illinois, 1915, pp. 17-34.

5. Boynton and Upton: School Civics, Supplement, pp. 40-51.

6. Guitteau: Government and Politics in United States, ch. $\mathbf{x}$.

Elected Executives of the State. The State constitution declares (Art V, sec. I): "The executive department shall consist of a governor, lieutenant-governor, secretary of state, auditor of public accounts, treasurer, superintendent of public instruction, and attorney general, who shall each, with the exception of the treasurer, hold his office for the term of four years from the second Monday in January next after his election, and until his. successor is elected and qualified. They shall, except the lieutenantgovernor, reside at the seat of the government during their term of office, and keep the public records, books, and papers there, and shall perform such duties as shall be prescribed by law." In many respects Illinois' executive department is "hydra-headed," and therefore lacks unity of action. Decentralized power - away from the center - is a favorite principle of American government, and Illinois only follows historic precedent in her executive department. 
The Governor is the chief executive officer in Illinois. He must be at least thirty years of age, and a citizen of the United States and Illinois for the five years next preceding his election. He is chosen at the general election the first Tuesday after the first Monday in November of the Presidential election years. His term begins the second Monday in January following his election, provided the State legislature has organized by choosing officers so that in joint session it can canvass the votes cast for the executive officers and declare them "duly elected." There was a "deadlock" in the House in the 48th General Assembly over the election of a speaker, lasting three weeks. ( I) In consequence, Governor Charles S. Deneen and the other executive officers had their terms prolonged because their Democratic successors could not be declared " duly elected," nor be qualified for office by giving their bonds and taking the oath required of each State officer.

The governor's salary is fixed by law and is now $\$ 12,000$ and the executive mansion at Springfield.

His Legislative Powers are, (a) to send a message to the General Assembly at the beginning of each session; (b) to sign or veto bills $;^{\mathbf{1}}$ (c) to call the Assembly in special or extraordinary session whenever, in his judgment, the occasion requires; and to adjourn the Assembly to such a time as he thinks proper, if the houses disagree over the date, provided it is not beyond the first day of the next regular session.

Power of Appointment. With the consent of the Senate, the governor may appoint all officers whose appointment or election is not otherwise provided for. The Legislature is

${ }^{1}$ For description of his veto power, see pp. I47-I48 (How a Bill Becomes a Law). 
strictly forbidden by the constitution to elect or appoint any such officer, so that it may not usurp the appointing power of the governor.

The number of positions, great and small, filled by appointment of the governor, is about five hundred. The more important ones are: Offices in the State militia; factory, grain, and mine-inspectors; members of the geological survey, Lincoln Park and West Park Boards in Chicago; the fish commission, State charities commission, and the Illinois park commission; the State highway department, the State board of administration to care for the twenty charitable institutions; members of various examining boards for trades, business, or professions licensed, or regulated, by the State, in order to protect the lives, health, or property of the citizens, as dentists, pharmacists, architects, doctors (who are examined by the State board of health), barbers, plumbers, and a State superintendent of insurance; trustees for the penal institutions and for the five normal schools; three members of the board of pardons; commissioners of labor; five members State public utilities commission; State board of arbitration to try to prevent strikes by arbitrating the differences at issue through State aid; three members of the State mining board; six members of the mine rescue station commission, created immediately following the terrible Cherry disaster and now maintaining three rescue stations and three mine rescue cars in the mining regions of the State; food and game commissioners; four superintendents of the free employment agencies. This long list is only a partial one. (2) Each session of the Legislature creates new boards and commissions that increase the governor's appointing power. Keep up with these through the Session Laws published 
usually by the middle of August of every odd year. Power of Removal. The governor himself can be removed only by impeachment. Charges are preferred through a majority vote in the House of Representatives and the impeachment is tried by the Senate acting as a court of justice. Two-thirds of the senators must concur to convict. No governor of Illinois has ever been impeached. The impeachment and removal from office of Governor Sulzer of New York, October I9I3, has given recent illustration of the danger of this method of trial when controlled by the political enemies of the executive.

Pardoning Power. The governor may grant reprieves, or delayed sentences, commuted or lessened sentences, and full pardons for all offenses committed against the State; but he can not grant a pardon before the conviction of the offender. He has the advice of the State board of pardons, which investigates all applications for pardons, and makes recommendations to the governor, but he is not compelled to follow their advice. A criminal may also be released in other ways. Under the indeterminate sentence and parole laws, after serving one year, if his conduct in prison has been good, he may be released on parole. If, however, he breaks his parole, he may be arrested and made to serve out his sentence without a new trial.

Other Powvers. The governor is commander-in-chief of the State militia and may call them out in case of strikes or mobs. The adjutant-general, whom he appoints, is practically the head of the militia. The fighting strength of the State or its militia, consists of all able-bodied male persons between the ages of eighteen and forty-five, except certain persons exempt by the laws of the United States, 
All such persons enrolled in the militia may be called out in time of danger in the State or nation. Usually the militia consists of men who voluntarily enroll in the Illinois National Guard, of which the governor is commander-inchief, acting through the adjutant-general. All enlistments are for three years. There is also a naval branch called the Illinois Naval Reserve.

The governor may request the President of the United States to send Federal troops into the State to quell any unusual disturbance which the militia cannot control. The governor may also request of the President the extradition of fugitives from justice who have broken the laws of Illinois and fled to a foreign country. Persons who have committed a crime in Illinois and fled to another State may be returned for trial through requisition papers granted by the governor of the State to which the fugitive has fled. The governor of Illinois must make request for such papers.

Social and Political Powers. The governor is often the head of his political party in the State and has an unrivaled opportunity to build up his own "political machine" through his control of State patronage, familiarly known as the State "plum tree." His influence in his party is great because of this appointing power. A State-wide civil-service law, vigorously carried out, would do a great deal toward correcting this condition and putting the State service on a genuinely efficient basis. The present civilservice law is excellent as far as it goes; but it is too limited to cover the needs of the State.

The governor has many social duties in attending all kinds of public meetings and opening many conventions and conferences; he also welcomes and frequently entertains distinguished visitors to the State. 
The Lieutenant-Governor. If the governor is removed by impeachment, resignation, or death, the lieutenant-governor succeeds to the office. He must have the same qualifications as the governor and is elected at the same time for the same term. Whenever the governor is absent from the State, the lieutenant-governor acts for him. Governor Dunne was indeed absent from the State, for good reasons, a number of times after his inauguration February I9I3. Lieutenant-Governor O'Hara was thus left acting governor an unusual number of times. The only work required of him in the meantime is to preside in the Senate and cast a vote if there is a tie. $\mathrm{He}$ is not required to reside at Springfield during his term. His salary is $\$ 2,500$.

The Secretary of State. This elected executive officer is custodian of the great seal of Illinois and affixes it to all important documents; publishes the laws; keeps all State papers; distributes public documents to any citizens requesting them; issues certificates to corporations presenting legal charters; has charge of all State property at Springfield. His salary is $\$ 7,500$ per year.

The Treasurer has charge of all State funds and pays them out on a warrant issued by the auditor. By a recent law he is required to turn over to the State all interest allowed by the banks on deposits of State money. Formerly he was allowed to retain such interest for his own use. His term is two years and he can not serve two consecutive terms. His salary is \$10,00o and the bond required is $\$ 500,000$. His large salary is due in part to a recognition of the disadvantage he is under through his short term. This short term and no immediate chance of a second one are among the devices by which Illinois safeguards the public pocketbook. 
Auditor of Public Accounts. He is called the "watchdog of the State treasury" because he is bookkeeper for the State and must balance accounts each month with the treasurer. With the governor and the treasurer, he determines the tax rate required to raise the amounts appropriated by the Legislature. He also issues all warrants on the treasurer for the payment of State money. Salary is $\$ 7,500$.

Attorney General. Is the legal adviser of all State officers and of the one hundred and two State's attorneys who represent the State in the counties. He draws up all contracts where the State is a party and prosecutes or defends all lawsuits for and against the State. His salary is $\$ 10,000$, and this amount is supposed to secure a good legal adviser for the State departments. But until the voters of the State demand a State government run for their interests more than for the politicians of some party, we can not expect the best lawyers of the State will be willing to accept this office, even if the salary is fair compensation.

Superintendent of Public Instruction. Is given under Public Education, ch. xii, p. I68.

These seven elected executive officers are legally quite independent of each other although the governor is responsible for the faithful execution of all the laws and therefore has general oversight of all the departments. The heads of departments must make annual reports to the governor and any special reports he may request.

Would Illinois gain through greater unity in her State government? Give two arguments, pro and con, on this question. 


\section{PERTINENT QUESTIONS}

I. If greater unity in State government is desirable, how could it be brought about?

2. Give the historical reason for this universal American principle of "decentralized power"?

3. Why are we beginning to question its wisdom for the twentieth-century State?

4. Why is it difficult for the governor of Illinois to carry out any far-reaching public policy?

5. What are the constitutional relations between the governor and the General Assembly?

6. How is the governor dependent on the Legislature?

7. Is the Legislature in any sense dependent on the governor?

8. How does the State civil-service commission assist the governor?

9. It is almost impossible to obtain fresh, up-to-date information from State officers. The reports of State officers and commissions are printed about ten months after the year for which they give statistics. How can this very inconvenient custom be remedied?

Io. Who is responsible for the printing of all State reports? 


\section{CHAPTER XI}

\section{STATE JUDICIARY}

REFERENCES :

I. Constitution of Illinois, Art. vi.

2. Revised Statutes, 1915, chap. xxxvii, secs. $1-76$.

3. Greene: Government of Illinois, pp. 90-94.

The constitution of Illinois makes definite provision for a system of courts, from the highest to the lowest, in the following words:

"The judicial powers... shall be vested in one supreme court, circuit courts, county courts, justices of the peace, police magistrates, and in such courts as may be created by law in and for cities and incorporated towns." (Art. vi, sec. I.)

To aid in understanding the interrelation of our laws, from State to Federal, the following diagram from Guitteau's Government and Politics in the United States, p. I I7, is worth study:

OUTLINE A. OUR SYSTEM OF LAW.

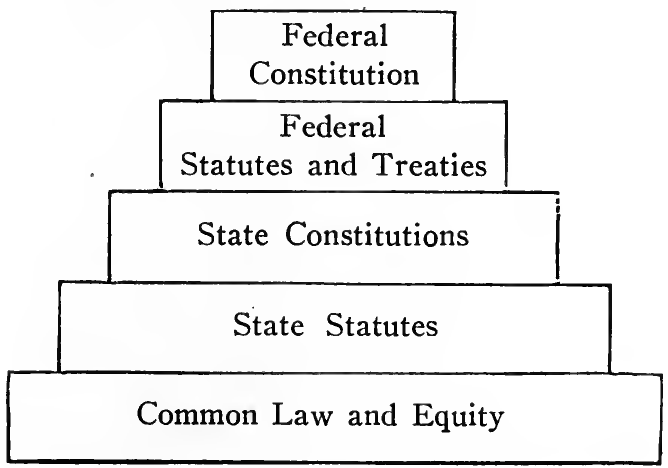


Common Law is the customary, or unwritten, law that prevails in this country. It is derived from England, and is the great body of English customs, established through centuries of usage, brought to America by the English colonists, and cherished by them as their most precious legal heritage. It has been greatly modified by decisions of judges in this country and by statutes. In Illinois the statute provides "that the common law of England so far as applicable, ... shall be considered as of full force until repealed by legislative authority." (Rev. Stat., I9I I, ch. xxvii, sec. I.)

OUTLINE B. THE COURTS OF ILLINOIS

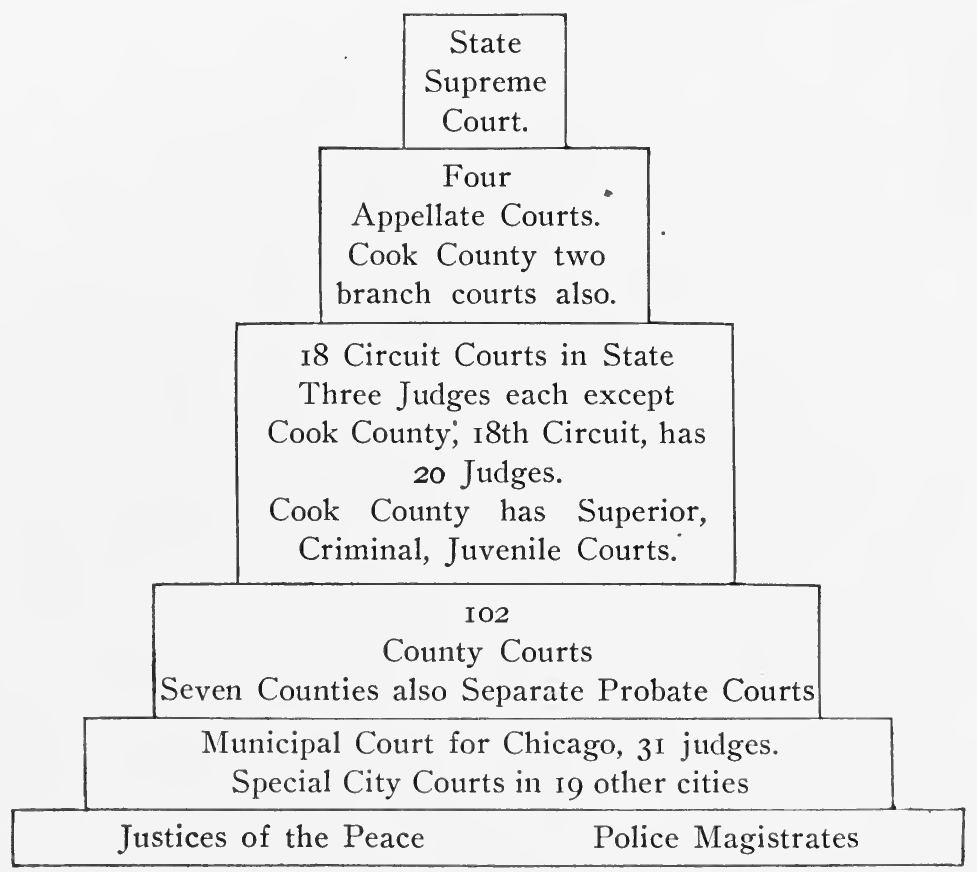


Equity means justice. "The aid of a court of equity is invoked where one has suffered a wrong which no actual law forbids, or where there may be complicated accountings too detailed for the swift action of a court of law." For instance, you may suffer wrong through the act of some agent for your property where he has broken no law and yet you have suffered the loss of a large sum of money. You would try to recover your money through an equity case. In Illinois any court presided over by a judge is a " court of law and equity," but in some of the States there are separate courts for the two kinds of causes. An equity case is always a civil action.

United States Courts in Illinois. There are three United States district courts, Northern, Southern, and Eastern, and a United States circuit court of appeals held in Illinois. The United States district court for the northern district, eastern division (Chicago) has two judges assigned, Judge K. M. Landis and Judge George A. Carpenter. The western division of the northern district holds court at Freeport. The southern district holds court at Springfield and Quincy. The eastern district holds court at Danville, Cairo, and East St. Louis.

The Municipal Court was created by act of the Legislature for Chicago and under the power of an amendment to the State constitution (I904) allowing special legislation for Chicago. This municipal court act had to be approved by the voters. In addition there are now nineteen small cities in the State, as East St. Louis, Peoria, and Springfield, that have a special city court having a concurrent jurisdiction with the State circuit courts in their respective cities.

Jurisdiction of a Court may be of four kinds: Original, if a case must begin there; appellate, if the case 
has been tried in a lower court and has come up on appeal; concurrent, when there are two or more courts having the same kind of jurisdiction, and final, if the case must end in that court with no chance of appeal to a higher court.

In what court in the United States is the jurisdiction always final? Has any Illinois court final jurisdiction? What courts have no juries?

The work of the justice of the peace and the police magistrate has already been described. For the municipal court, see pages 27,28 , I6 I.

Lawyers. All lawyers in Illinois must be formally admitted to the bar after passing an examination. These legal examinations are arranged by the State supreme court, and every lawyer in the State admitted to the bar is an officer of the court, and must render obedience to the orders of the court. Any lawyer, or attorney, who fails to obey a court order, or to show proper respect to the judge, or to other lawyers in court, may be fined for "contempt of court," if the judge chooses to exact such a penalty. Many judges, however, tolerate conduct and language in their court rooms from lawyers trying cases before them that never ought to be permitted. The dignity of our State and local courts would be greatly improved if all the judges in the lower courts were as particular about the decorum observed in their court rooms as are the Federal judges.

Supreme Court. The supreme court is the highest in the State: only one court in the land is higher. What one? There are seven judges, elected for nine years, first Monday in June: one from each of the seven judicial districts into which Illinois is divided. They choose one of their number for chief justice. Their sessions are all held at Springfield, beginning in October. Their principal, or 
"first-hand jurisdiction" is cases involving the constitutionality of Illinois laws, cases involving taxes, habeas corpus, and mandamus cases. Many appealed cases come up from the circuit and appellate courts. There is no appeal from their decisions unless the United States law is involved, when the case goes direct to the United States Supreme Court.

Appellate Courts. (Four: two branch courts in Cook County.) There are four principal appellate courts and two branch courts for Cook County, which makes a district by itself. Three judges are named by the supreme court to act as appellate judges in each district from the large number of circuit judges elected by the voters. They are appointed for three years, but are generally reappointed if they do good work. It is counted an honor to be thus chosen by fellow judges for the specialized work of the appellate court. Cook County, making one of the appellate districts, has to have nine judges appointed to care for the large number of cases appealed mainly from the municipal courts of Chicago. The county pays half the salaries of these State judges, who preside in the courts of Cook County. There are no juries in the appellate courts and nearly all cases tried are those appealed from the county, circuit, or municipal courts.

Circuit Courts. (I8.) Illinois is divided into eighteen circuits, Cook County making the eighteenth. Three judges are elected the first Monday in June from each circuit except the eighteenth, and they serve six years. From Cook County twenty judges are elected and the number is increased nearly every session of the Legislature. County judges are constantly called to serve in Cook County to fill the places of the circuit judges chosen for 


\section{I64 ACTUAL GOVERNMENT IN ILLINOIS}

appellate duty. The circuit courts care for the cases appealed from the county courts and for any cases arising between citizens living in different counties.

Outline the three State courts, supreme, appellate, and circuit, under the following topics:

I. Composition.

2. Manner of choosing.

3. Term of Office.

4. Jurisdiction.

a. Original.

b. Appellate.

c. Final.

5. Salary. 


\section{CHAPTER XII}

\section{PUBLIC EDUCATION IN ILLINOIS}

\section{REFERENCES :}

1. Revised Statutes, ch. cxxii (School Laws, our final authority).

2. Greene: Government of Illinois, pp. 190-205 (a very clear, complete account).

3. Boynton: School Civics with Civics of Illinois, pp. $60-63$ (brief but clear).

"Religion, morality, and knowledge being necessary to good government and the happiness of mankind, schools and the means of education shall forever be encouraged."

This sentence from the famous Ordinance of $1787(\mathrm{Am}$. Republic, p. 50) embodies the principal reasons for the free public school system of Illinois as well as the other States formed from the Old Northwest Territory. It deserves memorizing by every citizen in the State and is the Magna Charta of our public schools. In harmony with the Ordinance, the present State constitution says: "The General Assembly shall provide a thorough and efficient system of free schools whereby all the children of this State may receive a common-school education." (Art. viii, sec. I.)

School Taxes. Nine-tenths of the money needed to support the public schools comes direct from taxes levied in each school district. In addition to the local taxes of the districts, the State levies a school tax of $\$ 3,000,000$ 


\section{I66 ACTUAL GOVERNMENT IN ILLINOIS}

annually. ${ }^{1}$ This is appropriated by the General Assembly at each biennial session. The Legislature of I9I I doubled this tax, which helps the less wealthy districts maintain better schools. This State school fund is divided by the auditor of public accounts among the IO2 counties of Illinois in proportion to the number of children under twenty-one years of age. The county superintendent of each county receives his share of the State fund from the county collector and distributes in turn to the township treasurers in the county. The township (school) treasurer then divides it between the school districts in his township according to the children under twenty-one.

Permanent School Funds. The same process is used in distributing the permanent school funds held by the State. The largest of these for the common schools is the Township Fund, amounting now to more than fifteen millions. By the Enabling Act of 1818, Section 16, or its equivalent, in every township was given by the National Government for the support of schools in that township. This grant amounted to over one million acres. All of it has now been sold except about seven thousand acres, lying principally in Chicago. The Chicago schools receive nearly a million dollars annually from the rentals of these unsold school lands. Their market value is hundreds of millions and increasing each year.

In some of the Western States, like Idaho and Wyoming, where they have profited by our mismanagement of school lands, no district tax is levied, but the schools are run entirely from rentals from unsold school lands.

State School Fund. The second largest permanent fund for the common schools is the State school fund.

1 Act of Legislature, 19r3. 
Three per cent., less one-sixth (one-half of one per cent.) of the proceeds of the sale of all public lands in Illinois was given to the public schools. The one-sixth deducted was set aside for higher education.

The surplus revenue fund is an interesting one because of its source. Illinois received nearly half a million dollars in I835 from the National Government when, for the first time in its history, the United States was not only free from debt, but a capitalist. Congress voted to "permanently loan" these surplus millions to the different States, and suggested the application of this unexpected cash to the school fund; which wise advice Illinois followed. The principal of all these funds has been spent by the State long ago; but Illinois has pledged her honor to pay to the common schools annually the interest on the funds at six per cent.

Higher Education in the State. At the head of Illinois' system of higher education stands the State University at Urbana. This great State school, or rather collection of schools, owes its existence to a large gift of land made by Congress to the loyal States during the Civil War. This grant was made for the express purpose of establishing colleges whose leading object must be to teach "agriculture and the mechanic arts." The result of this wise action by Congress was the founding of agricultural colleges in all of the Western States. The Illinois Industrial University was founded then as the State's response to this offer. The university was reorganized as the "University of Illinois" in I885.

The University is governed by a board of trustees including the governor, president State Board of Agriculture, superintendent of public instruction, and nine men and 
women elected by the men and women voters of the State. The Legislature makes very large appropriations for the maintenance of the University in addition to the interest received from the permanent funds for higher education.

There are also five normal schools for the training of teachers, located in the different sections of the State, at DeKalb, Carbondale, Normal, Macomb, and Charleston.

State Superintendent of Public Instruction. The Siate superintendent of public instruction is the ranking school officer in the State, although his actual power is not great because the local boards manage the schools in their districts quite independently. He is elected for four years; in November of the alternate even year. His election is planned to come in the even year between the election of Presidential electors, to keep the State school offices out of politics as far as possible.

Duties. His duties are mainly advisory. The county superintendents report directly to him and he is their legal adviser. He must send a biennial report to the governor and recommend any changes in the school laws he thinks wise; he issues State certificates for ten years and for life to teachers who pass certain examinations and is ex-officio a member of the University board of trustees. He is constantly called on to give public addresses on educational questions and an able superintendent may thereby exert much influence indirectly on the school system of the State.

County Superintendent. This officer represents the State in school matters in the county; is directly responsible to the State superintendent, and must report annually to him. His salary is paid by the State. He distributes the county's share of the annual State school fund of three million dollars to the towns in his county; conducts exami- 
nations and grants certificates to all teachers, who without such certificate could not draw salary from the taxes; holds teachers' institutes each summer and other meetings during the year; visits all public schools in the county and suggests improvements. $\mathrm{He}$ is particularly required to supervise and assist the rural schools. A movement has been started under the county superintendents to encourage the teaching of agriculture and give more practical education to the boy and girl in the country. (Ch. iv: p. 75.)

Local School Administration. The Illinois school law makes the congressional township the school township and unit of school government (Rev. Stat., ch. cxxii, sec. 30). Therefore a school township always coincides with some congressional township. Remember, however, the school officers are in no sense town officers. The actual management of the schools, however, is vested in the school district. If the school district contains a thousand people there must be a board of education elected by the men and women voters of the district. This board shall consist of a president, elected for one year, and six members elected for three years, the president and two members to be chosen annually. There must be three additional members for every ten thousand people up to a board of fifteen. Cities above one hundred thousand population (Chicago) must have a board of education of twenty-one members, appointed by the mayor with the consent of the council, for three years; seven to be appointed annually. The board selects the president from its own members. This is an excellent illustration of the method pursued by the General Assembly to evade the provision against special legislation in the State constitution. Cities are grouped in classes according to population. In the class referred to above, of 
course Chicago is the only city to qualify. Why not be honest and remove from the constitution such a "dead letter" so far as it affects Chicago, and give that great city much needed legislation directly? (I)

The board of education in Chicago must get the consent of the council to issue bonds, buy or lease school sites, erect or purchase school buildings. For the powers and duties of the board, see Rev. Statutes, chapter cxxii, sections I78I79; also pp. I7 I, I72 of this book. School boards and directors throughout the State have the right to condemn prithe owner." This is the famous right of eminent domain (2), the right of the "greatest good to the greatest number," and is granted school boards in Illinois directly by law. (Rev. Stat., ch. cxxii, sec. I48.) If the owner of the property desired for the use of the schools refuses to accept a reasonable price, then condemnation proceedings are begun in court; the price may be fixed by a jury and the owner is compelled to accept it. This is just, because no individual, or group of individuals, ought to block the rights of a larger group. The property rights of a private citizen are amply protected in the United States constitution. (See Constitution of the United States, Amendment V.)

School Township Trustees. Each school township elects three trustees as the business officers for its school affairs. Their term is three years. One is elected annually on the second Saturday of April, by the legal voters of the township, men and women. In school townships where the boundaries coincide with those of a town (3), the school trustees are elected on the same day as the town officers (the first Tuesday in April), for convenience, and to save the expense of a separate election. Any resident, twenty- 
one years old, is eligible for the office; but no two trustees shall reside, when elected, in the same school district, nor can any person be trustee and director at the same time.

Duties of School Trustees. The trustees have three main duties: (a) To divide the township into school districts for the convenience of those who attend the schools; (b) to appoint a township treasurer who handles all school funds in the township; (c) to hold all school property, both lands and buildings, in their name. They may also establish a township high school if the people of the township vote for one at an election called for that purpose.

District Boards of Directors. ${ }^{2}$ After a township is divided by the trustees into school districts, each having less than one thousand population (unless it contains an incorporated city or village), each district must elect three directors who are charged with the management of the district school. Their term is three years and one is chosen annually on the third Saturday in April by the legal voters of the district, including men and women. Neither trustees nor directors receive any pay for their services. Women are eligible for directors. The board of directors must establish and keep in running order one or more free schools for at least i Io days of actual teaching each year, to accommodate all children in the district between the ages of six (compulsory age is seven) and twenty-one. The directors appoint the teachers, fix their salaries, levy the school tax for the district, and have entire charge of the schools. They are the educational officers for a school district, while the trustees are the business school officers for the entire township.

High Schools. Any school board has the right to es2 Rev. Stat., ch. cxxii, secs. 121-125. 
tablish a high school to provide the first steps toward higher education. The high school is properly named the "people's college," and ought to be the most democratic school in all our system. Public kindergartens, manual training, domestic science, music, and drawing may be provided under special teachers if the voters of the district so authorize the board through an election.

Compulsory School Law. School must be held in every district at least I Io days in the year and all children between seven and fourteen are compelled to attend under penalty. The parents may be brought into court by the truant officer and fined if they fail to keep their children in school the required months. Children who are feebleminded, blind, or crippled are provided with special instruction, or legally excused from attendance.

Township High Schools. This form of high school is in much favor in Illinois. There are about one hundred in the State. A township high school is organized, after a special election has authorized its establishment, by electing a township board of five members, who have full control of the high school. The advantages of such a high school are: (a) more taxable property, hence larger revenue, better buildings, grounds, and equipment; (b) more careful supervision because the township board gives its time and effort to the high school alone; (c) more pupils can attend without paying tuition. It also enables the poorer districts in a township to unite their funds and get such an advanced school, which otherwise they could not afford to have. April is the usual month in Illinois for school elections. Consult the Revised Statutes, chapter cxxii, for the exact Saturday.

Teachers' Pension Fund. Illinois has a Teachers' 
Pension Fund, created by act of the Legislature in 1915, which applies to all the cities and school districts in the State except Chicago and Peoria. The fund is created by certain amounts deducted from the salaries of all teachers coming under its provision and the remainder comes from the State. The pension granted after twenty-five years of teaching is four hundred dollars. The teachers contributing elect three of the five trustees who manage the fund and the State superintendent and State treasurer are ex-officio members of the pension board.

\section{SUMMARY ILLINOIS SCHOOL SYSTEM BY OUTLINE}

(a) State superintendent (I)

(b) County superintendents (I02)

(c) School directors (3 in each township)

(d) Township school trustees (3 in each township)

(e) Township treasurer (I)

(f) Board of education (elected) (7-15)

(g) Board of education (appointed) (2I)

\section{PERTINENT QUESTIONS}

I. Which of these officers are elected? Which appointed? Which receive any salary?

2. To which school offices are women eligible? (Rev. Stat., ch. cxxii, sec. 290.)

3. To whom are school taxes paid?

4. How does a teacher get her salary?

5. If refused payment, could she legally recover her salary?

6. How would you secure an athletic field for your school?

7. How often may text-books be changed in your district? (Rev. Stat., ch. cxxii, sec. I46.)

8. How could your township get a township high school?

9. What difference in government between a township and a city high school?

Io. How could your district get a kindergarten? What children could attend it? 


\section{I74 ACTUAL GOVERNMENT IN ILLINOIS}

II. Do the citizens in your district use the schoolhouse for meetings outside of school hours?

I2. If not, why?

I3. Why should the property of a bachelor be taxed to support the schools?

14. Why must the property of a non-resident pay a school tax? 


\section{CHAPTER XIII}

\section{THE MERIT SYSTEM IN ILLINOIS}

STATE, COUNTY, AND CITY CIVIL-SERVICE COMMISSIONS

GENERAL REFERENCES

I. Edward Cary: The Merit System - The Spoils System.

2. Elizabeth Luther Cary: A Primer of the Civil Service and the Merit System.

3. Clinton B. Woodruff: The Merit System in Municipalities.

4. The Business Value of Civil-Service Reform.

5. Imogen B. Oakley: Spread of Civil-Service Reform Principles through Women's Clubs.

6. W. W. Vaughan: Every Man on His Own Merits. (These are furnished schools by Women's Auxiliary, Massachusetts Civil Service Reform Association - usually without charge. Address Miss Marion C. Nichols, 3I Beacon Street, Boston, for list of their valuable publications and reports.

SPECIAL REPORTS FOR ILLINOIS

7. Eighteenth Annual Report Cook County Civil-Service Commission, September, I9r3.

8. Report, I9I4, of Chicago Civil-Service Commission.

9. Report, I9I4, Illinois State Civil-Service Commission. (Send to the County, City, or State authorities for these interesting reports.)

"Civil-Service Reform has survived the doubts of its friends, as well as the rancor of its enemies, and has gained a permanent place among the agencies destined to cleanse our politics and to improve, economize, and elevate the publc service."-Grover Cleveland. 
"Civil-Service Reform is as democratic and as American as the public-school system."- Theodore Roosevelt.

Meaning of Civil Service. "The purpose of civilservice legislation is to provide a non-political method of determining fitness of applicants for public positions, and to prevent their removal for any political or religious reason. The method of determining fitness for these positions is by practical, competitive examinations, open to all citizens alike. From these examinations eligible lists are made up by rating applicants in the order in which they have passed an examination. And from these lists, in the same order, positions are filled.

"The purpose of the plan is to place the public civil service on a business-like basis, so that public business may be transacted as efficiently and honestly as in any private concern." - First Annual Report of the Illinois Civil-Service Commission.

History of the Movement. The United States Government has had a civil-service law - The Pendleton Act — since I883. The spoils system - "to the victor belong the spoils of the enemy" - came in under President Jackson, about 1830 , and for over half a century that degrading, wasteful system of office-holding prevailed throughout the country and covered State and local governments as well as Federal.

"Without the shedding of blood there is no remission of sins." The American people were at last aroused to the dangers of this vicious system by the death of President Garfield, shot by a disappointed office-seeker. The Pendleton Act was the response to awakened public opinion that a "public office is a public trust," and an office-holder only a trustee for the public who employs him. 
The post-office department was the first one placed on a merit basis, and its great growth in amount of business and in efficient service to the people dates from that time. At present nearly 260,000 Federal officers are in the classified service - about two-thirds of the entire Federal service and the major part of the clerical positions in all ten cabinet departments at Washington are under this common-sense method of determining fitness to hold government positions. Thomas Jefferson's three qualifications for office-holding have never been improved on: (Ist) Is he honest? (2nd) Is he capable? ( 3 rd) Will he be faithful to the constitution? Honesty, efficiency, patriotism - where will you find a better official creed?

City Civil Service. In I 895 the first civil-service law in Illinois passed the General Assembly, applicable to cities only, and after a referendum vote. Under its provisions Chicago and Evanston each adopted civil service and thus became the pioneer cities in Illinois to begin the merit system. Chicago has only about fifty positions exempt out of its huge pay-roll of 24,000 persons. This does not count the school teachers or the judges of the municipal court.

The Chicago civil-service commission has done some notable work during its twenty-one years of life. The special features of its excellent record (2) are: Equal salaries for equal duties, or for all employees in the same class; promotion through examination only and for efficiency alone; appropriate examinations, or those having a more direct bearing upon the requirements of the position to be filled.

To examine scrub women in arithmetic and grammar is absurd. A test for physical strength and endurance, added to some knowledge of practical sanitation, is much more to 


\section{I78 ACTUAL GOVERNMENT IN ILLINOIS}

the point. The Chicago commission proposes to carefully adjust its tests to the requirements of the work to be performed. It is already a pioneer in introducing practical tests as a prominent feature of its examinations. These are best understood by a few illustrations:

A bridge-tender is wanted. The commission requires a strong man with perfect sight and hearing; the mental examination for such a position forms a small part of the whole test. Then the appointee is required to take sight and hearing tests from time to time, to be sure his eyes and ears continue perfectly normal.

A meat inspector is needed. One day he takes a written examination on the theoretical part of his work. The next day he is taken to the stock-yards and told to select healthy and diseased meats; if diseased, to state what is the trouble and if there is a possible remedy.

For the fire and police departments fourteen physical tests for strength, agility, and endurance are required. A given height, weight, girth of chest, and lung expansion are also necessary. The result we see in the thirty-five hundred Chicago policemen, who are as fine a set of men physically as you will find anywhere. To show how this weeding process operates, look at one of the examinations for patrolmen. Out of eight hùndred and forty-eight applicants, only about twenty-five per cent. passed all these severe tests.

The Chicago commission also maintains a character-inzestigation department, where the honesty and reputation of the applicant is looked up, just as a bonding company investigates the character of a prospective bank cashier before they will issue a bond for him. A common trick to evade civil-service regulations was for a strong man to take 
the physical tests, a bright one the mental examination, and an entirely different person - but all three under the same name - to get the appointment. This is prevented by the system of identification used, where a print of the forefinger is made at different times under all these tests, and of course must be identical.

There has been a very decided change in sentiment on civil-service questions during the last few years. Formerly the merit system was regarded mainly as protecting the employee from grasping politicians and spoilsmen. Now the viewpoint has shifted to the interests of the tax-paying public. The efficiency of the public service is the leading object. As the counsel for the Chicago commission once expressed it, "The individual may suffer, but I feel I represent and am to safeguard the City of Chicago," - a very radical change of sentiment from the welfare of the individual to the benefit of the community, but quite in line with the trend of modern thought on many topics. A large number of cities in the State now have civil-service commissions and have placed their firemen and policemen at least under merit rules.

The Merit System in Cook County. The county civil-service commission of three is appointed by the president of the county board for a term of three years; but the terms are so arranged that only one commissioner is appointed each year. Under the present law the consent of the county board is not required. Cook County had the honor of the first woman civil-service commissioner (3) in Illinois and the second in United States. The county charity service owes much to her wise administration. The charitable institutions of Cook County were first placed under the merit system in 1895 ; but for nearly eight years the 
administration of the law was only a joke. The fact that not even a stenographer was employed by the civil-service commission is proof the law was a dead letter. Then public opinion began to demand better enforcement of the law. The account that follows was largely taken from the admirable Eighteenth Annual Report of the Cook County CivilService Commission, issued three years ago but just as illuminating now as then.

Purpose of the Act. "The purpose of the County Civil-Service Act is to maintain a system of employment in the various county offices and institutions, based solely on merit and efficiency. Positions in the county service are not owned by the successful candidates or political leaders who happened to have a majority of the votes at the last election, but belong to the whole people of the county. Every citizen, according to his ability to do the work required in the county service, should have exactly the same opportunity for employment possessed by any other citizen. The examinations, which test ability, should be practical and impartial tests, directed to the sole question of relative fitness to perform the duties of the position. The county hospital requires doctors; the State's attorney, lawyers; the county treasurer, clerks; and the county recorder, record writers. Appointments to these or other county positions ought never to be based upon service in a ward club, or upon supposed loyalty to a factional political leader. Politics has nothing whatever to do with a doctor's care of the sick, with the prosecution of crime, with the making out of tax bills, or the writing up of titles to real estate. Ability to do the work required, as measured by reasonable standards of efficiency, is under the Civil-Service Act made the sole basis of public employment. The elimination under persistent 
and systematic treatment of inefficient employees and of conditions of employment which breed waste and inefficiency are alike a benefit to the public and to the public employees."

A sweeping civil-service law, putting all the large fee offices under merit rule, was passed by the Legislature in I9II.

The Exempt Service. "On the 2oth of February, I9I3, these great fee offices of the county, the county treasurer, the county clerk, the sheriff, the offices of the clerks of the circuit, superior, county, probate, and criminal courts, the election commission, the State's attorney's office, the assessor's office, the board of review, the coroner's office, and the recorder's, became exempt from the provisions of the Civil-Service Act because the supreme court found that the Legislature had failed to print some forty words of the I9I I Act. A new civil-service act, so worded it will stand the test of the supreme court and be declared constitutional, that will place these great fee offices under merit rule, is one of the imperative needs of Cook County. It is estimated a half million dollars annually could easily be saved the tax-payers through such a law honestly enforced."

A recent illustration of the truth of this estimate is furnished by the county agent's office. Before an examination was required, forty-five investigators were employed to determine the condition of persons applying for county poor relief. After examination, only seven were found necessary to handle all such investigations.

How the Spoils System Works. "The system under which appointments are now made to the exempt offices does not differ much from the system in vogue for twenty years past. Candidates for office are usually asked to sign 
the customary pledge to place all positions in their departments at the disposal of the County Central Committee of the party winning the election. Some department heads may succeed, after negotiation, in retaining a few positions for their personal friends and helpers. Necessity compels the retention of a few old employees who are familiar with the routine work of an office." For example, since the last county election, less than a dozen experienced employees out of an office force of over seventy, were retained by the board of assessors to do the very important work of assessment of property in the richest county in the State.

"The agreement is usually enforced that the great bulk of the county positions shall be pooled in the hands of the County Committee. The County Committee allots these positions, graded according to salary, to the various party leaders, according to the size and nature of the party vote polled in their districts. Factional differences modify the size of certain shares, but the principle of allotment has been maintained. When a vacancy in the county service occurs, the privilege of filling it belongs of right to a particular party leader. $\mathrm{He}$, in turn, has obligations in the wards and precincts under him. Grotesque misfits of men in positions where the only thing they understand is the salary attached, are the inevitable consequences of this system.

"A burdensome political obligation is placed upon county employees in the exempt service. Though they are paid from the county treasury, a considerable part of their time is devoted to partisan work. An employee must be able to 'deliver his precinct,' or to show a certain number of votes in it, if he expects to retain his position. Increase in salary and promotion depend on the same practical test. His job is always at stake. He will be dropped from the 
pay roll if he fails to deliver the requisite number of votes. There are about forty thousand public employees within the geographical limits of Cook County. A civil-service law is the only barrier against the exploitation of these men and women for political purposes. Until such a law is applied to all these positions, the voters of Cook County have but a slender chance to determine real political issues, or to decide upon the relative merits of candidates for elective offices."

The Illinois primary law is at present a party measure, and nomination by petition the only chance for a non-partisan candidate. But such a candidate has slender chance of winning at the polls when he must overcome the strenuous partisan work of a crowd of office-holders whose " jobs" depend on the success of their party.

One of the important sections in every civil-service law forbids an employee from electioneering of all kinds, nor can he be compelled to contribute to any campaign fund. His time and his pocketbook are thus protected from the raids of candidates for the elective offices. "That the merit system of Cook County has survived the attacks of its enemies is proof of the soundness of its principles. Twice the people of the county have endorsed the merit system; the last time in I9Io by a majority of nearly I00,000 votes." There are now (October I9I6), I, IOO positions in the classified service, or places under the civil-service law. One great evil is usually the large number of temporary appointments - those made for sixty days - without the applicant passing any examination. Sometimes these applications are renewed so many times that the position really becomes " exempt," and persons who have honestly passed an examination and been placed on the eligible list are 
thereby kept out of an office to which they are entitled. When the reform county civil-service commission began work (March I, I9I3), there were 462 temporary appointees in a charity service of $\mathrm{I}, 074$ positions. By holding I I I examinations in six months, they finally reduced the tempo.* rary appointees to 147 out of a charity service of 1,074 persons. This is one of the vital tests of an honestly enforced civil-service law. Measured by this standard, as well as other tests, the merit system in Cook County has gone backward since the change in administration in I9r4. The present commission is of the old-style political type. ${ }^{1}$

The Merit System in the State. The youngest of the civil-service acts of Illinois, that of 1905, is the State Act, when the General Assembly by statute applied the merit system to the seventeen charitable institutions of the State. The present number of such institutions is twenty-one. This law was a hard-won victory for civil-service reform after a long struggle in the Legislature, and was only a shred of the original bill introduced. The only positions exempt in the charity institutions are the superintendents of the State hospitals and State schools, whose important places are still regarded as "spoils of office," to the disgrace of the State. A list of the State charitable institutions and their locations will be found in the chapter on State Charity Service, pp. 196 and 197.

The State of Illinois cares for about 22,000 dependents in the State institutions. By far the largest number are insane patients, cared for in the nine State hospitals, and

1 The valuable Eighteenth Annual Report of the Cook County CivilService Commission was largely the work of its president, Robert Catherwood. Other members of the commission were Miss Anna E. Nicholes, secretary, and W. F. Corby. (4) 
these helpless state wards are especially in need of wise and experienced care. The protection of these helpless men and women from political employees, and their wiser, more humane treatment, were the principal reasons for the adoption of the Illinois Civil-Service law of 1905. The entire treatment of the insane in our State has been revolutionized since that year.

Illinois was the first State to introduce oral examinations in connection with the written and physical tests required. For such positions as house-father and house-mother at the reform schools the personal qualities, tact, and commonsense of the applicants count far more than any mental test. These qualities can be determined better by a personal interview than in any other way. The Illinois commission has developed a practical system for such interviews, always providing a stenographer to record every question and answer, and keeping all such records as part of the examination.

At the State Eye and Ear Infirmary in Chicago the entire staff of oculists and aurists, about eighty, serve without pay, and yet submit to a hard written examination, and then are taken on some designated day into the clinic room and all the cases for that day, nearly one hundred, are put under their charge to test their practical skill. These applicants perform all operations under the eye of skilled specialists, who of course take care no harm comes to any patient through the awkwardness or ignorance of the candidate for a staff position. The doctors estimate it is worth ten thousand dollars a year to be known as a member of the operating staff of the Illinois Eye and Ear Infirmary, so they can well afford to give their services to the State for a term of years. 
The most recent example of a practical examination conducted by the State Civil-Service Commission was one for grain-inspectors. The management of this examination was turned over to the grain-committee of the Chicago Board of Trade, and they were told to give exactly the kind of test they would in their own private business. After writing on certain questions, the applicants were given twenty-seven samples of wheat, oats, barley, corn, and rye, and were obliged to test them and grade them according to their knowledge gained through previous experience in handling grain. The type of grain-inspector selected through such an examination shows its practical commonsense. (5)

Conclusion. A good law is recognized by its foes as well as its friends. The professional politician, the man who desires office solely for what he can get out of it, the old-time spoilsman, these men of course will fight the merit system. But in their opposition, if they only can be compelled to come into the open and declare their real sentiments, they will reveal themselves so unmistakably that their constituents will know beyond a shadow of a doubt what manner of public servants they are. Here lies the great benefit of a roll-call vote on an important measure, in the General Assembly, and why the legislators avoid its telltale black and white evidence whenever possible. To the mass of private citizens there is much calm satisfaction in watching the struggles of certain unfortunate law-makers, impaled like flies on pins, when they are caught in a rollcall vote.

Keep a sharp lookout on the State senator and the three representatives from your district for their vote on every civil-service bill. Watch their record on the roll calls as 


\section{THE MERIT SYSTEM IN ILLINOIS}

reported in the daily papers and the bulletins of the Legislative Voters' League, and judge the men by this touchstone of good citizenship.

\section{PERTINENT QUESTIONS}

I. Why are so many politicians against the merit system?

2. How will the tax-payer be benefited by an honestly enforced civil-service law?

3. Give six arguments in favor of the merit system.

4. Can you give any good argument in favor of the spoils system?

5. Why is this method of office-holding called the "spoils system"?

6. Show how the name fits the act.

7. How does the merit system protect the office-holder?

8. What are political assessments?

9. What is meant by electioneering? Can you give an actual illustration of it?

ro. What do you consider the best way to select a civil-service commission?

II. If the civil-service commissioners are mere political appointees, what evils result?

I2. Whom does the "exempt" office-holder obey? Whom does he serve? Who pays his salary? What kind of public service will he give? 


\section{CHAPTER XIV \\ STATE CHARITY SERVICE}

\section{REFERENCES :}

I. Revised Statutes, ch. xxiii, I-50.

2. Annual Reports Board of Administration, Address Secretary, James Hyland, Springfield, Ill.

3. Annual Reports State Charities Commission, address Secretary, A. L. Bowen, Springfield.

4. Institution Quarterly (Official organ of the public charity service of Illinois): published jointly by Board of Administration, Charities Commission, and Psychopathic Institute; editor, A. L. Bowen, Springfield. The quarterly is furnished free of charge to any citizen of Illinois who wishes regular information regarding Illinois' public charity service.

5. Greene: Government of Illinois, ch. xii, "Wards of the State." (Read this chapter if possible.)

THE PLATFORM OF PRINCIPLES OF ILLINOIS' CHARITY LAW

"To provide humane and scientific treatment and care and the highest degree of individual development for the dependent wards of the State;

"To provide for delinquents such wise conditions of modern education and training as will restore the largest possible portion of them to useful citizenship;

"To promote the study of the causes of dependency and delinquency and mental, moral, and physical defects, with a view to cure and ultimate prevention;

"To secure the highest attainable degree of economy in the business administration of the State institutions consistent with the objects above enumerated, and this Act, 
which shall be known as the code of charities of the State of Illinois, shall be liberally construed to these ends." (Rev. Stat., ch. xxiii, sec. 2.)

State Board of Administration. The amended charity law of Illinois, in force July I, I9I2, is worth study. It is necessary first to understand the legal machinery provided in the Act to carry out its purpose as stated in the preamble. At the head stands the State Board of Administration of five members to manage the twenty-one charitable institutions supported by the State. The five members of this board are appointed by the governor with consent of the Senate, for six years, and not more than three can be of the same political party. They are each paid $\$ 6,000$ per year and actual traveling-expenses. The executive secretary and all the employees of the board are under civil-service rules, but not the members of the board itself. These positions are still part of the governor's patronage. Headquarters are at Springfield and the members of the board must give their entire time to their duties. Illinois began the experiment of a single board instead of one for each institution, January I, 1910, and the success gained in more economical, efficient management is bringing the State charity service slowly but steadily to a higher grade. (I)

State Charities Commission. The same law that established the Board of Administration (January I, I9IO), also created a State Charities Commission of five members, appointed by the governor, with consent of the Senate, but serving without compensation except necessary traveling expenses. Their term is five years. The secretary of State must provide the commission with an office, stationery, and office supplies. Their headquarters are at Springfield and 


\section{0

they have a paid executive secretary who is under the civil service. Their duties are "to visit and investigate the whole system of public charitable institutions of Illinois."

The duties of the Board of Administration and of the Charities Commission are not the same. The members of each are required by the law to visit at unexpected times, both day and night, all the charitable institutions of the State at least every quarter. But the field of work for the Board of Administration is principally financial and executive, the buying of all supplies, care of the land and buildings, the business and property side of the institution; while the Charities Commission is charged with the oversight of the patients, inmates, and children cared for; to see that they are humanely treated and placed where, if improvement is possible, they may have a chance for recovery. Such matters as the physical condition of patients, their food, clothing, cleanliness, medical care, recreation, employment, if able to work, course of study in the schools, kind of teachers, discipline,- all these things are inspected, complaints heard and investigated by the Charities Commission and their secretary, who gives his entire time to this work and is a man thoroughly trained in public charity service. To see that the kitchen, dining-room, dormitory, laundry, bathroom, cellar, storeroom, hospital ward, and schoolroom of every State charitable institution is in good condition and suited to the needs of the patients and inmates is a very important work, difficult to do. The Charities Commission investigates and reports to the Board of Administration what they find and how conditions may be improved at the twenty charitable institutions now established. The new State hospital for the insane at Alton has not yet been opened, nor the Surgical Institute for Crippled Children 
even located. A State colony for improvable epileptics is also being built at Dixon. After a campaign of nearly twenty years, the Legislature ( I9I2) made a suitable appropriation for the site and buildings and the colony will be opened in $1916 .{ }^{1}$

The State Board of Administration appoint the superintendents of all the charitable institutions and may remove them at pleasure, as they are not protected by the civil service - a point that needs reform. The legal power of control, of course, is vested in the Board of Administration, while the Charities Commission has only visitorial and advisory power. The law states that "five persons" and "reputable citizens" are to compose the board and commission. At present no woman is a member of either, but there is nothing in the wording of the law to prevent a woman serving, and these positions are ones particularly adapted to women, and where the services of the mother, the housewife, and home-maker would be of special benefit to the unfortunate wards of the State.

Boards of Visitors. In addition to the Board of Administration and the Charities Commission just described, the law provides a board of three visitors, one of whom shall be a woman, for each one of the twenty charitable institutions; to be appointed by the governor and serve without any pay except actual traveling expenses. These three visitors must make thorough monthly inspection of the institution and report their findings to the State Charities Commission within ten days of their visit. Generally the board of visitors live near the institution and therefore will feel a local pride and interest in helping the superintendent through kindly suggestion and advice to keep the institution up to the best standard of service. Any unkindness to patients and inmates will be more quickly detected and

${ }^{1}$ See pp. 193-194, 197. 
stopped if these monthly inspections are conscientiously made.

Complete State Care of the Insane. July I, I9I2, the Board of Administration assumed control of the Cook County asylum for the insane at Dunning. There are about 3,000 patients in the asylum. The legal name is now the Chicago State Hospital. At last Illinois has complete care of the insane within her borders. Even those in private sanitariums are supervised by the Board of Administration, as no such private hospital can receive patients suffering from any mental or nervous disease without a license from the State Board, which can be revoked at any time the hospital fails to come up to the standard of care set by the board.

There are at present (October, 1916) over 16,400 insane men, women, and children in the nine State hospitals, out of more than 22,000 State wards in all the charitable institutions. (See The Institution Quarterly, June, I9I6, p. 8.) (2) When the new hospital being built at Alton is finished, it will provide for 1,500 more. It is unfortunate that the opening of this fine new hospital for the insane has been so long delayed. All the State hospitals are badly over-crowded and that means adequate care cannot be given to the patients no matter how earnestly the hospital staff and attendants may try to relieve the situation. By far the heaviest burden on the taxpayers for the charity service of the State is imposed by the care of this unfortunate class.

Psychopathic Institute. This fact makes the scientific study of the cause and cure of insanity carried on at the State Psychopathic (mental disease) Institute of very great value. The institute also provides invaluable training for the doctors at the State hospitals, who are all 
encouraged to take a six-weeks' course in the institute every year. They are working toward a solution of the big problems, "What causes insanity?" "Is it curable?" "If so, how?" The facts just stated from the records of the State hospitals emphasize the importance of sound mental habits to every one. The constant practice of a few simple, well-established rules of mental hygiene would help decrease this great Illinois army of the mentally sick by diminishing the supply. "Beware of alcohol! Be clean in mind and body. Be temperate in work and recreation. Don't worry. Look on the bright side of all your troubles."

All the State hospitals have training schools for nurses and attendants. Dental service is now provided in all the State institutions.

State Institutions for Children. The State of Illinois has assumed complete care of the blind, deaf, delinquent. feeble-minded child, of the dependent child in the poor house, and of the soldiers' orphan. A list of all these institutions is found at the end of this chapter and should be studied. The Surgical Institute for Crippled Children (I) is another much needed State charity. A law has been passed creating such an institution under certain conditions as yet unfulfilled.

The Colony for Epileptics is to be a farm colony located on a thousand-acre tract of suitable land to give all the out-door employment possible to the inmates. The buildings are to be only two stories and of fire-proof construction. There are to be inclines instead of stairs in all the buildings and every possible precaution used to prevent the epileptics housed in these cottages from injuring themselves in their seizures. It is hoped the Board of Administration will make all reasonable speed in getting this much-needed institution ready for use. (3) It is estimated there are now in 
Illinois at least ten thousand persons suffering from epilepsy, and their need of State care is very great. (4) Only young people and cases possible to cure will be cared for at this new farm colony near Dixon.

Care for the Blind. In addition to the State school for blind children at Jacksonville and the Industrial Home for the Blind in Chicago, there is a new work being undertaken throughout the State to teach blind men and women in their homes. Teachers are sent to these adult blind on request and a very excellent work has been begun. Illinois has an excellent record for its very humane care of the blind. (5)

Soldiers' Homes. Illinois is generous in her care of the old soldier and sailor, too feeble to work. The State also makes special provision, in separate homes, for the widow of the man who has fought for his country, and for his orphaned children. "These provisions for veterans and their families may be regarded not as charity in the ordinary sense but as the discharge of a public debt." (Greene, Government of Illinois, p. I68.)

Delinquent Boys and Girls. The St. Charles School for Boys is on the cottage plan; has a large farm connected with the institution and cares for about six hundred delinquent boys. A few miles away, at Geneva, is the State Training School for Girls, where delinquent girls are cared for, educated, and trained for some useful occupation when they leave the institution at twenty-one. By good conduct a girl may earn a much shortened sentence.

Poor Relief. The State requires the counties to care for the pauper class, or dependent poor. This includes all persons who for any reason are not able to support themselves and have no family or relatives to care for them. 
The county may build an infirmary, or poor house, located on a farm owned by the county; or the persons to be provided for may be "boarded out" with some citizen of the county. This method is rapidly being abandoned as expensive and not very humane, because of the natural desire to make all the money possible out of the county paupers. Instead the counties are building county infirmaries to house and feed their poor who must be cared for in an institution. In counties under township organization, the town supervisors act as overseers of the poor and may give "out-door relief " in their homes, or send the dependent poor to the County Home, or infirmary, as seems best. The universal dread of this institution in the minds of the self-respecting poor is the best comment on its general reputation and plainly shows where public charitable methods need revision. Where poverty is the result of sickness, accident, or misfortune, why should the victim feel so disgraced if compelled to enter the county poor house that many times an assumed name is given on entrance for fear some former acquaintance may discover the compulsory retreat? On the other hand, public charity is too often abused by the vicious, the lazy, and the "political poor," who are able to care for themselves, or have relatives who should be compelled to assume the burden of their support. The sensible, humane poor master has a difficult problem to solve in sifting. out the "wheat from the chaff" in the human rubbish heap with which he must deal. In the non-township counties, the county board appoints a "justice of the peace or other suitable person" to serve as overseer or poor master.

Greatest Need of the Charity Service. The charity service of Illinois costs over three million dollars a year, exclusive of the large sums spent by the counties in poor 


\section{I96 ACTUAL GOVERNMENT IN ILLINOIS}

relief, and the Board of Administration is responsible for the wise use of this large sum. The board is trustee for all the property of these twenty institutions, which is valued at fourteen million dollars. This large investment in land, buildings, equipment, and the millions spent each year from the taxes, represent the sincere effort of this great State to give wise, kindly care to the twenty-two thousand unfortunate wards within its borders. There should be no politics allowed in this care for the insane, blind, deaf, feebleminded, and delinquent. Public opinion should demand of the governor absolutely non-partisan, merit appointments to the Board of Administration. Citizens should serve notice on every governor of Illinois that the positions on the board can not be used to reward his political friends. The Board of Administration never ought to be considered a part of the "spoils of office." It goes without saying that no superintendent of any State charitable institution ought to be dependent on the election returns for his tenure of office. Yet this has always been the case, and it is true now. The superintendents of these institutions usually conform to the politics of the party in power and change with the downfall of the party. The sooner Illinois protects the heads of her charitable institutions, particularly the superintendents of the State hospitals for the insane, by a civilservice law, the sooner the State institutions will move toward the place Illinois ought to take in the care of the dependent wards of the State.

\section{STATE CHARITY SERVICE}

State Charitable Institutions and Their Locations

Lincoln State School and Colony (for feeble-minded).... Lincoln Illinois School for the Deaf..................Jacksonville 
The Illinois School for the Blind. Jacksonville Illinois Industrial Home for the Blind.

.Chicago, cor. Douglas Boulevard and igth St. The Illinois Soldiers' and Sailors' Home.............. Quincy The Soldiers' Widows' Home of Illinois............Wilmington The Illinois Soldiers' Orphans' Home................. Normal The Illinois Charitable Eye and Ear Infirmary.

Chicago, 904 W. Adams St.

The State Training School for Girls.................Geneva The St. Charles School for Boys................... Charles State Psychopathic Institute (for study of the causes and possible cure of insanity. A similar institute is needed at the

Chicago State Hospital at Dunning) ..............Kankakee Illinois Surgical Institute for Children............. Not located (The law creating this "Surgical Institute for Crippled Children" requires a donation of 160 acres of land for a site from the community where it is located. No city, village, or country district in the State has yet offered this prize. There is great need for this institute where a crippled child under fourteen could be placed for surgical treatment, which would probably save such a child from becoming a public charge.)

I11. State Colony for Improvable Epileptics. Opened 1916 .. Dixon For Care of the Insane

Elgin State Hospital........................... Elgin Kankakee State Hospital....................... Kankakee Jacksonville State Hospital ....................Jacksonville Anna State Hospital..............................nna Watertown State Hospital ...................Watertown Peoria State Hospital (for chronic or incurable cases)..... Peoria Chester State Hospital (criminal insane) .................. Chicago State Hospital (since July I, I9I2).......... Dunning Alton State Hospital (being built) $\ldots \ldots \ldots \ldots \ldots \ldots \ldots$. Alton 


\section{CHAPTER XV}

\section{AMENDMENT OF THE ILLINOIS CONSTITUTION}

\section{Constitution, Article XIV}

\section{FIRST, OR CONVENTION METHOD.}

A. Proposal.

I. By a two-thirds vote in both houses of the General Assembly to submit the question of a constitutional convention to the people at next general election.

2. Submitted to people at such election: total majority of all votes cast at the election must be favorable to the convention.

3. General Assembly must in that case at next session provide for such convention by law.

4. Number of delegates must be double the number in the Senate (102), to be elected in the same manner, place, time, and districts as State senators.

5. Convention to meet within three months and frame a new constitution

B. Ratification.

Submitted to people at special election: total majority of all votes cast at that election must be favorable to the new constitution or it will fail of adoption.

This method would take about six years and requires a vote in two sessions of the Legislature and at a general and a special election by the people. 
II. SECOND METHOD OR "SHORT CUT."

A. Proposal.

Single amendment at a time.

Must be by two-thirds vote in both houses.

B. Ratification.

Total majority of all the votes cast at the next general election must be in favor of proposed amendment if it is carried. Is printed on separate or "little ballot."

C. Restrictions on this method of amending:

I. Only one amendment may be proposed by General Assembly at any one session.

2. Assembly may not offer an amendment to the same article oftener than once in four years.

A constitution nearly fifty years old, made in the nineteenth century, for a State with only $2,500,000$ people, can not suit the unforeseen needs of the twentieth century and a population close to six millions.

Could a constitution be nailed down any tighter than Illinois'? How many years. will it take to get the amendments needed if Illinois has the constitutional dress she absolutely requires? The present constitution "was born before the trolley, the electric light, the telephone, the automobile, the sky-scraper. These familiars of our daily life were unknown to the framers of the constitution."

To " amend the amending clause" - Article XIV - allowing a number of amendments to be submitted to the people at once, has been proposed as a practical " short cut" through part of our difficulties. But it would give us only temporary, partial relief. In the end our necessities would compel us to resort to a constitutional convention to obtain simplicity and flexibility of form and relief 
from too many independent taxing bodies. The demand for a constitutional convention is being heard most persistently from the northern half of the State, particularly in Chicago and Cook County, where three hundred and seventy separate taxing bodies (I), with widely varying rates, lead to great confusion in government and waste of public money.

An editorial in the Chicago Tribune, October 23, 1913, entitled, "Give Us a Convention," is of interest on this point. A constitutional convention is urged " at the earliest practical date as the surest means of obtaining additional charter power for the city and as the only means of securing the power to consolidate the three municipalities" (Chicago, Cook County, sanitary district).

The council is urged to petition the governor of Illinois to call a special session of the Legislature "to consider the supreme need for holding a constitutional convention."

"But Chicago ought not to look at the constitutional convention proposal from a selfish point of view. We are citizens of the State and the State needs constitutional relief. Not only Chicago, but the State, has long outgrown the constitution of 1870 , and while our needs may be more dramatic and urgent, they are not more real than those of the entire State."

The legislatures of I9I 3 and I9I 5 refused to allow the people of Illinois to vote on this vital question of a constitutional convention preferring the " piece-meal plan." What will the 5oth General Assembly do with the question? Like Banquo's ghost “it will not down." 


\section{CHAPTER XVI}

\section{ILLINOIS MOVING FORWARD}

Illinois has the honor to be the first State east of the Mississippi to grant the ballot to women. This makes the tenth State in the Union to give "votes to women." Although not full suffrage, it grants greatly enlarged powers to women. A description of the essential parts of this famous law follows:

"The Woman Suffrage Law. Since I89I Illinois women have been allowed to vote for all school officers except State and County Superintendent of Schools.

"The Illinois legislature of I9I3 extended to women the right to vote for the following named officers: Presidential Electors, Member of the State Board of Equalization, Clerk of the Appellate Court, County Surveyor, Members of Board of Assessors, Members of Board of Review, Sanitary District Trustees, all officers of cities, villages and towns (except police magistrates), Supervisor, Town Clerk, Assessor, Collector and Highway Commissioner and also the right to vote upon all questions or propositions submitted to a vote of the electors of any municipality or other political division of the State.

"The wording of the law is such that some officers, like city judges, municipal court judges, commissioners in cities under a commission form of government, forest preserve president and commissioners, park commissioners and road district clerk, not common to every city, district or town 
are really covered by the law, because such officers are city officers or town officers, or to be voted for by 'legal voters.'

"The same legislature also enacted a law allowing women to vote at primaries for the officers named above.

"Other semi-official persons like delegates and alternates to national nominating conventions, members of state central committee, precinct and ward committees may also be voted for by women. Women may hold any of these offices because the word "male" is not used in describing the qualifications of the officer. "Women are eligible to appointive positions and deputyships.

"The women privileged to vote must be either native born or naturalized citizens of the United States, having resided in the State one year, in the county ninety days and in the election district thirty days next preceding any election therein, and they must be registered in the same manner in which men are registered.

"The days for registration precede the primaries and elections by three weeks and are advertised beforehand.

"The city and school elections generally occur annually in April and the county and State elections biennially in November, though special elections may be called, for other dates.

"The statute provides for separate ballots and ballot boxes in order that the women may not vote for all the officers for whom men vote. There is a similar provision in the school suffrage law of I89I, as the legislature has no power to extend suffrage to women for officers mentioned in the constitution. Men only are now allowed to vote for the most of the State officers, county officers, judges, members of congress and the State legislature. To give women the same rights, the Illinois constitution must 
be amended. Such an amendment, if submitted to the people by a vote of two-thirds of the I9I7 legislature, that is, by thirty-four senators and one hundred and two representatives, and then voted for by a majority of all voting at the November, 1918, election would become a part of the constitution and fully enfranchise Illinois women." 1

State Aid Good Roads Law. The new State Aid Good Roads law, in effect July I, I9I3, creates a new State Highway Department of five commissioners, two of whom must be engineers. Their term is six years, and the governor appoints them. They will supervise all roads built with State aid, prepare a uniform plan of construction, and a road map for the State. The county board of each county must appoint a county superintendent of highways for six years from a certified list submitted by the State commission. This superintendent of highways will oversee the construction of the State roads in the county, advise the State commission of any peculiar local conditions in that county, and act as a State agent for the commission. Certain highways in the county are designated by the county board as "State Aid roads," subject to the approval of the State commission, which is responsible for making the various county roads fit into the general plan. The State pays half the cost of construction of such highways and also bears the entire cost of keeping them in repair.

Each township or road district, if in a county not under township organization, decides by referendum vote whether it wants one highway commissioner or three to look after

${ }^{1}$ This material is taken from a pamphlet, "The A. B. C. of Woman's Suffrage Rights in Illinois," by Catharine Waugh McCulloch, and is used throngh the courtesy of the author who is also author of the law. 


\section{ACTUAL GOVERNMENT IN ILLINOIS}

its country roads, except the State Aid roads. ${ }^{2}$ This is the worst feature of the law, because the county ought to be the center of local management as well as construction. Not more than twenty-five per cent. of the total mileage of country roads in any county can be State Aid roads. There is no aid for roads in cities or villages.

Funds. The funds come from three sources: The State automobile tax, which now amounts to $\$ 800,000$, an appropriation from the General Assembly, and the county tax. The new law revives a poll tax of one to two dollars levied on all men between twenty-one and fifty, and is payable in cash, not labor. Enlarged powers of taxation and bond issue for road building are granted the counties. After April I9I4, the supervisor in each town becomes treasurer of the Road and Bridge Fund, making that town office of more importance.

Cook County has approximately I,200 miles of country roads, so the county is entitled to 300 miles of State Aid roads. These must be principal highways, and connect with the State roads in adjoining counties.

Western, Milwaukee, Archer Avenues, Halsted and Twelfth Streets have been designated by the county board as the first State Aid roads in Cook County. They are being made of concrete. ${ }^{3}$

This law is the first sensible attempt to "pull Illinois

${ }^{2}$ Roads and Bridges Act, 19I3, sec. I58.

${ }^{3}$ There has already been planned and surveyed a great transcontinental highway of concrete running from New York to San Francisco, to cost approximately $\$ 75,000,000$. The cement companies of the United States have offered to furnish the cement for this highway at a cost to the companies of $\$ 10,000,000$. This Lincoln Memorial highway will run along the south boundary of Cook County and pass through Joliet and Dekalb. 
out of the mud," and is full of promise for the future. Farm property will be immensely benefited by these new State Aid roads, and indirectly, the cities and villages will profit by better transportation for all farm products. ${ }^{4}$

Public Utilities Commission. Two bills concerning public service companies and corporations were made law by the Legislature of I9I3. A bi-partisan public utilities commission of five members to be appointed by the governor for six years was created. The salary is large $-\$ 10,000$ - and each commissioner must devote his entire time to the duties of his office and hold no other office nor engage in any other business.

All public utility corporations must supply the commis-. sion with any information required, and their books can be inspected at all times. The law says: "All rates and other charges made by any public utility shall be just and reasonable." Every unjust or unreasonable charge made is declared unlawful and prohibited. If the language of the law means what the words usually mean, then the public utilities commission can absolutely regulate the price of gas, electric light, ice, and water; railroad, express, telegraph, and telephone rates; warehouse and storage charges, and the price paid for oil throughout Illinois. Certainly this is tremendous power to place in the hands of five men, and the entire value of the law rests in the type of men the governor appoints. There is provision for an appeal from any ruling of the commission to the circuit court of

${ }^{4}$ See synopsis of the State Aid Good Roads Law prepared by the Roads and Bridges committee of the Cook County Board. Also Revised Roads and Bridges Act, in effect July I, I9I3. Secure this act from secretary of State, Springfield, or from your county board. Get a road map of your county from the county board and notice the State Aid roads on it, if any in existence. 
Sangamon County and from that direct to the State supreme court. The act went into effect January I, I9I4. (I)

The greatest objection to the law comes from Chicago, because there is no clause allowing "home rule" for that city, or control of its own great public-service companies. Chicago, through its mayor and council, has unitedly protested against such a great increase in the power of the State at the expense of the cities. Some control and regulation of public utilities is greatly needed, and if the law is firmly, impartially, and wisely administered, both the public-service companies and the people at large will benefit equally.

Municipal Ownership of Public Utilities. The second law is: "An act to authorize cities to acquire, construct, own, and to lease or operate public utilities and to provide the means therefor." (Session Laws, I9I3, pp. 455-459.) This act, in force July I, I9 I 3 , gives the cities, villages, and towns of Illinois the right of municipal ownership, operation or lease of their street car, telegraph, telephone lines; water, gas, electric light, cold storage, and power plants of every kind; public warehouses, storage places, docks, and to fix the rates and charges for the services rendered by such public utilities.

How must a city proceed under the act if it wishes to construct and operate a street-car line? First an ordinance must be passed by the council providing for municipal construction and ownership of such street-car line and providing for a bond issue in payment of same, the bonds to run not longer than twenty years. This ordinance must be approved by a referendum vote, and the city may then proceed to build and operate the new municipal car line. If a car line was already in existence, and the franchise about 
to expire, the city could proceed under the new powers to buy the privately owned car line, repair it, and run it. The same is true of a gas, electric light, or ice plant, a warehouse, or telephone line. If the private company will not sell its property at a fair price, then the city may condemn it under the right of eminent domain. (2) Instead of issuing bonds, a new method is provided in the act to pay for such municipally owned utilities. If authorized by the voters, the council may issue " public utility certificates," to be paid for out of the profits of the utility. This plan has the advantage of making the plant pay for itself. The utility may be mortgaged as security for the redemption of these certificates, and there is danger of foreclosure of this mortgage by which a private corporation could easily. get possession of a plant built by the city, run it for twenty years, and reap all the financial rewards of the experiment. This possibility ought to make the citizens in any community keenly alive to the necessity of an honest, efficient, city government and a strictly enforced civil-service law for all city employees before they attempt municipal ownership of their public utilities. The act gives broader powers to Illinois municipalities than any recent law.

Municipal Coliseum Law. The Legislature has conferred the right on cities and villages under 500,000 population to levy a tax of three mills to build and one mill on the dollar to maintain a public coliseum for purposes of assembly and recreation. There must first be a favorable referendum vote to build such a coliseum. The mayor, or the president of the village, appoints three directors to serve without pay for three years to have entire control of the use of the coliseum as well as to build and equip it. Bonds running thirty years may be sold to pay for the 
building and payment secured by a mortgage on it. Every public municipal coliseum so erected is for the "free use and benefit of the people for lectures, concerts, public assemblies, and all other educational purposes, and for free amusements and entertainments," subject only to the rules and regulations laid down by the three directors. The coliseum is to be used " for the greatest benefit to the greatest number," according to the terms of this very progressive law. In small rural communities a suitable place for public gatherings is hard to find. Usually the church or schoolhouse is the only available place, and neither building is large enough or central enough to serve community needs. A public municipal coliseum would be a genuine community and social center and fill a real community need. No city or village need build such a coliseum unless it wants to, for the law provides absolute "home rule" in the matter. (Session Laws, I9I3, pp. I42-I45.)

Legislative Reference Bureau. Several States, particularly Wisconsin and Massachusetts, have established such a bureau, and the members of their State Legislatures have found it a great service in drafting bills and voting intelligently on bills introduced. Illinois has joined this group of " forward looking" States, and provided by law for such a reference bureau. The duty of this bureau is to " collect, catalogue, and index laws, periodicals, documents, and digests" from other States and arrange this valuable material in the most convenient form for the use of members of the Legislature.

The reference bureau is composed of the governor, who is ex-officio chairman, and the chairman of the committees on judiciary in the Senate and the House. This committee of three appoints a paid secretary who gives his entire 
time to the work of the bureau and keeps it open the year round, Sundays and legal holidays excepted. (Session Laws, I9I3, pp. 391-392.)

Workmen's Compensation Act. "A business that does not care for its own waste is a parasite." The appalling number of deaths and accidents to working men, women, and children in industries led Dr. C. R. Henderson to make the statement quoted.

The present workmen's compensation act is not compulsory. An employer may voluntarily accept its provisions, or he may serve notice that he will not be bound by its terms. But if he fails to file such notice, he is obliged to come under the act. An Industrial Board of three members, appointed by the governor for six years, is created to enforce the act. This board is composed of an employer, an employee, and a " representative citizen," who is neither, and the board must be bi-partisan.

The amount allowed for the death of a workman incurred in the industry is not less than $\$ 1,500$ nor more than $\$ 3,500$. Lesser amounts are paid for injuries received. In case of permanent disability, a small life pension, payable monthly, is provided. Any employer can withdraw from the compensation plan by giving notice to the Industrial Board and his own workmen; but such withdrawal does not affect the pensions for which he is already liable. The workmen employed by the State, county, and local governments are also protected by the law. This act marks a cautious beginning in Illinois toward making industry "carry its own waste."

Mothers' Pension Fund. This new law takes the place of the carelessly drawn law of I9I I and provides a pension of $\$ \mathrm{I} 5$ a month for a mother with one child under 
fourteen years old and \$Io per month for each additional child under fourteen, provided no relief is granted for any one mother to exceed \$6o per month. Alien mothers who have taken first papers toward citizenship are eligible as well as mothers who are citizens of United States. Both classes of pensioners must have lived three years in the county where relief is sought. If the father is living, but permanently unable to support his family, upon recommendation of the probation officer investigating the case, the mother and children may still obtain the pension. Relief ceases whenever a child becomes fourteen, unless that child is sick or has become crippled, when the pension may be continued until the said child is sixteen.

This pension is paid through the office of the county agent. The county board levies a tax of three-tenths of one mill on the dollar annually on all taxable property in the county, to be known as the mothers pension fund. The judge of the juvenile court, or the county judge in counties having no juvenile court, is charged with the administration of the law, and there are special probation officers for the investigation of every applicant for the fund. (See Juvenile Court in Cook County, pp. 78-79, for working of this new pension act in that county.)

Illinois Park Commission. Illinois is one of the pioneer States in the Mississippi Valley to create a State park. The Illinois Park Commission, of three members, serving without pay, was appointed by the governor in I9I I to acquire sites noted for their history or natural beauty and maintain the same as State parks. "The historic spot where the great tribe of the Illini Indians is said to have made their last stand, and the site of the French fort of Saint Louis," have been purchased, and the twelve hundred acres are now known as Starved Rock State Park. This 
beautiful park lies on the Illinois River in LaSalle County. The increasing number of people using the park shows how great the need of State-owned parks is. Cottages and camping grounds are being provided and every effort made by the Park Commission for the freest possible use of this great out-door playground. ${ }^{5}$

Child Labor Law. Illinois had an apology for such a law over twenty years ago; but the law passed in 1903 is the one of which the people are proud, and justly, because it is counted one of the best child labor laws in the country. No child under fourteen is allowed to work in any place where liquor is sold, and there is a long list of prohibited occupations, for which see Revised Statutes, I9I2, chapter xlviii, sections 20-20a. All children come under the compulsory school law until fourteen years old. At that time age and school certificates are required from parents and the school superintendent. Between fourteen and sixteen all hazardous occupations are forbidden and every such child employed in permitted occupations must be registered by a wall list giving name, age, and residence, which is posted in the establishment where he is employed. The child's working day is eight hours and must lie between seven a. m. and six p. m. The State factory inspector and his deputies are charged with enforcing the child labor law and a certain proportion of the deputy inspectors must be women, because they are keener in protecting the rights of the child. Every child must be able to read simple sentences and write legibly before a work certificate is granted. A fine is imposed for each violation of the child labor law. Illinois protects the children in part until they are sixteen. After

- Report Illinois Park Commission, 1912, is a very interesting document and will repay careful reading. 
that they are adults in the legal sense and must take their chances. Is it wise? Can you give any reasons for favoring a longer period for preparation for life occupation?

The Local Option Law. Since 1907 Illinois has had a "local option" law allowing any city, village, town, precinct, or township to become anti-saloon territory by popular vote and remain "dry" for eighteen months, when the question may be resubmitted on petition of a small number of voters. Under the terms of this act, over half the State of Illinois is "dry" territory. But the permission to reopen the question every eighteen months keeps the battle between the "personal liberty" advocates and the anti-saloon people always to the front. A decision of the State supreme court declared this local option law constitutional. "This insures the permanence of township local option in Illinois." The county local option law, unfortunately, was repealed in I913 - another evidence of the constant warfare between the liquor interests and the temperance sentiments of the people. A recent Legislature (I9I3) passed a new "dram-shop law" prohibiting the sale of liquor within four miles of the State University; but the residence district bill to keep saloons out of such districts of homes, was defeated through the influence of the United Societies, the powerful liquor organization in the State. Illinois needs to join the educational campaign being carried on in Massachusetts to teach the economic and civic waste caused by alcohol. The first municipal poster on this subject is recommended for thoughtful consicleration. This poster has been placed in every park, fire and police station in Cambridge, Mass., by order of the mayor and council.

Most of the laws described in this chapter were passed by the last two Legislatures and prove that Illinois is genuinely 


\section{ALGOHOL!}

THE PUBLIC THINKS: ..॰

It is only Heavy Drinkind that harms.

EXPERIMENTS SHOW:...

That even Moderate Drinkind Hurts Health, Lessens Efficlency.

THE PUBLIC THINKS : -..

-Alcohol braces us for hard work and wainst fatidue.

EXPERIMENTS SHOW: ....

That ALCOHOL IN NO WAY INCREASES MUSCULAR STRENGTH OR ENDURANCE.

\section{ALCOHOL LOWERS VITALITY; ALCOHOL} OPENS THE DOOR TO DISEASE

Resolved, at the International Congress on Tuberculosis, 1905, to combine the Fight Against Alcohol with the Struggle Against Tuberculosis.

At the Massechnsetts General Hospital, Boston, the use of Alcohol as a medicine declined 77 per cent. in eight years.

Most Modera Bospitals show the samo tendeacy.

Alcohol is Responsible for Much of Our Insanity, Much of Our Poverty, Much of Our Crime. OUR PRISON COMMISSIONERS REPORTRD TEAT 95\% OF THOSE WHO WENT TO PRISON IN 1911 BAD INTEM. PERATE HABITS.

YET TEC POBLIC SAYS :--- We need the Revenue from Liquot

THE PUBLIC SHOULD KNOW.--HOW SMALL IS THE REVENUE COmpared with the Costs of Carrying the Wreckade.

YOUR YONEY SUPPORTS THIS WRECKAGE.

YOUR WILL ALLOWS IT.

YOUR INDIFFERENCE ENDANGERS YOUR MATIOR.

Commercialized Vice is Promoted through Alcobol.

CITIZENS, THINK!

ARRAYED AGAINST ALCOHOL ATC ECONOMY, SCIENCE, EFFICIENCY, BEALTH, MORALTTY.

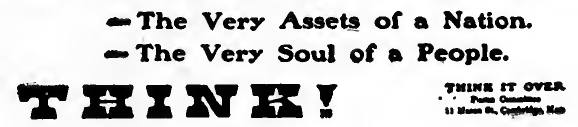

Used by Courtesy of The Survey, August 9, 1913

First Municipal Poster against Alcoholism in the United States.

Placed by authority of the mayor and park commissioners of Cambridge, Mass., in all parks and public buildings. 


\section{I4 ACTUAL GOVERNMENT IN ILLINOIS}

" moving forward" along the highway of progress. If Illinois will throw aside her outgrown State constitution and adopt one better suited to the needs of the twentiethcentury the centennial birthday of the State, so near at hand, will witness wonderful progress in effective government. [For legislation of I9I5 see Appendix C.] 


\section{APPENDIX A}

Reference List of Books and Pamphlets valuable for study of Actual Government in Illinois.

I. Beard, C. A. American City Government. Century Co. I9I2.

2. Boynton and Upton. School Civics with Civics of Illinois. Ginn \& Co. I9Io.

3. Campbell, W. H. Illinois History Stories. Appleton. I9Io.

4. Currey, J. S. History of Chicago. S. J. Clarke Co. 1912.

5. Debaters' Handbook Series. H. W. Wilson Co., Minneapolis. 1909.

6. Eastman, F. A. Chicago City Manual for 1915. Bureau of Statistics. Room I005, City Hall.

7. Fairlie, J. A. County and Town Government in Illinois. Annals American Academy, May, I9I3.

8. Fairlie, J. A. Report on the Taxation and Revenue System of Illinois. I9ro. Illinois State Journal Co., Springfield.

9. Fairlie, J. A. Report of Joint Legislation Committee of 47 th General Assembly. 1913.

Io. Forman, S. E. The American Republic. Century Co. I9I2.

II. Forman, S. E. Advanced Civics. Century Co. Revised ed.

12. Forman, S. E. Essentials in Civil Government. Illinois Edition. American Book Co. 1909.

13. Garner, J. W. Government in the United States. Illinois Edition. American Book Co. 19I5.

14. Greene, E. B. The Government of Illinois. Macmillan Co. I904.

15. Guitteau, W. B. Government and Politics in United States. Houghton Mifflin Co. I9II.

16. Hurd, H. B. Revised Statutes of Illinois. Chicago Legal News Co. I9I5-I9I6. 
I7. James and Sanford. Government in State and Nation. Scribners. I9I2.

18. James and Sanford. Our Government: Local, State and National. Illinois Edition. Scribners. I903.

19. Judson, Harry Pratt. Government of Illinois. Maynard Co. I900.

20. Mather, Irving $\mathrm{F}$. The Making of Illinois. A. Flanagan. I900.

21. McCleary, J. T. Studies in Civics. American Book Co. 1897.

22. Moody, W. D. Wacker's Manual of the Plan of Chicago. Chicago Plan Commission. I9I2.

23. Ostrogorski, M. Democracy and the Party System. Macmillan Co. I9I I.

24. Smith, G. W. Students' History of Illinois. Published at Carbondale, Illinois. I907.

25. Session Laws of Illinois for I9I5. Chicago Legal News Co. 26. Thomas, R. W. A Manual of Debate. American Book Co. I9Io.

27. Winchell, S. R. A Civic Manual. A. Flanagan. I9ı. 28. Wilcox, D. F. Great Cities of America. (Chap. IV-Chicago.) Macmillan Co. rgro. 


\section{APPENDIX B}

Valuable Publications of Civic Organizations in Chicago.

I. Chicago Association of Commerce. Reports and a weekly paper Commerce.

II. Chicago Bureau of Public Efficiency, 315 Plymouth Court, Harris S. Keeler, Director.

I. Park Government in Illinois. Dec., I9I I.

2. Growing Cost of Elections in Chicago and Cook County. Dec. I9I2.

3. The Voting Machine Contract. Jan., 1913.

4. The County Treasurer's Office. Nov., I9I3.

5. Nineteen local Governments in Chicago. 2nd ed. Mar., 1915.

III. City Club. 315 Plymouth Court. George E. Hooker, Secretary.

Bulletins.

IV. Illinois Equal Suffrage Association. 603 Tower Building.

I. A. B. C. of Woman's Suffrage in Illinois.

2. Illinois Lazes Concerning Women.

3. Woman Suffrage Law of Illinois. July, 1913.

All by Catharine Waugh McCulloch.

4. What Illinois Women Have Accomplished with the Vote.

5. How the Suffrage Law Was Saved in the Illinois Legislature, I9I5.

V. Legislative Voters' League of Illinois. Io So. La Salle St., Chicago.

The Assembly Bulletin, issued monthly.

VI. Municipal Voters' League. Iog No. Dearborn St., Chicago. Annual Reports on the Chicago Aldermen. 
VII. Woman's City Club. iı6 So. Michigan Ave. Amelia Sears, Director.

I. A Suggested Solution of the Garbage Question.

2. Catechism for Women Voters in Illinois. Nov. I9I3.

3. Handbook for the Women Voters of Illinois. Dec. I913.

4. Madam, Who Keeps Your House?

5. Mothering a Municipality.

6. The Larger Housekeeping.

VIII. Chicago Normal College. History and Government of Chicago, in the Educational Bi-Monthly.

IX. Chicago Public Library, Civics room, main building. Package Libraries for the Study of Civics. This magazine material is for circulation and can be had in duplicate for class use. 


\section{APPENDIX C}

Vital Statistics Law. The General Assembly of I9I5 gave the baby citizens of Illinois their right to a legal proof of birth and descent, so important in matters of residence, inheritance, voting, obtaining passports or work-certificates. "There is hardly a relation in life from the cradle to the grave where a record of birth may not prove of the greatest value." The law went into effect Jan. I, I916, and provides for registration districts and local registrars who must be city or town clerks where possible, or their deputies. All births must be registered within ten days, under penalty, and proper certificates containing all the information required by the United States Census bureau must be filed with the State Board of Health within thirty days. The executive secretary of the State Board is made superintendent of birth and death registration under the law. All burial permits are issued and recorded by the same authority subject to any sanitary regulations made by the State Board of Health. A fee of .25 for each birth certificate and burial permit is paid the registrar up to 5,000, and .Io for each ensuing certificate. In Chicago the registration is left with the health department but all original certificates must be filed in Springfield with the State Board of Health. An annual report of births and deaths must be published by the State Board with such data as "will serve to promote public health and the general welfare of the citizens of the state."

Commitment Law for the Feeble-minded went into effect July I, I9I5, after a campaign of thirty years to secure it. The object as stated in the title is, "to better provide for the care and detention of feeble-minded persons," and within the first six months of its operation $\mathrm{I} 50$ such persons were committed for life to the Lincoln State School and Colony. The law provides for a commission of three persons "two of whom must be qualified physicians - or one may be a qualified psychologist - to be selected 
by the judge on account of their known competency and integrity," to make a careful examination of the person thought to be subnormal and report their findings to the judge. Thereupon the person declared feeble-minded may be committed for permanent care to a suitable private or public institution or colony, to the great benefit of the community and the individual involved. This is the first time psychology has ever been recognized by law. This commitment law has attracted general attention throughout United States and copies have been requested from every section of the country. "Illinois is the first state to enact and put into practical operation so comprehensive a plan for the permanent segregation of its mentally deficient." 1

Consolidation Law for Chicago. Public opinion in Chicago - is slowly but surely moving toward consolidation of the 22 local governments within the city and county limits as the only certain remedy for numerous evils in the body politic, especially the burdens due to nearly four hundred separate taxing bodics within Chicago and Cook County. Various plans to get rid of useless and duplicated offices in city, county, township, sanitary and park districts are being suggested from several sources.

The General Assembly of I9I5 passed an act providing one method, although a clumsy one, to bring about this greatly needed reform. The act is very elaborate and includes a multitude of detail but fails to strike at the root of the matter. If adopted it would give the city council absolute control over the public library, the house of correction, the parks and townships lying within Chicago. But the great taxing bodies of the county, sanitary district, municipal tuberculosis sanitarium and board of education are not touched by the act. This law can be submitted to the legal voters by ordinance of the city council, at any general election or by petition signed by a certain per cent. of the voters. For adoption a majority of all the votes cast at such election is necessary and also "a majority in two or more of the local governments to be consolidated." This makes possible "piece meal consolidation," and will not do violence to any of the local gov-

1 The Institution Quarterly, June 30, 1916, p. 33. Used through the courtesy of A. L. Bowen, secretary, State Charities Commission. The members of this commission succeeded in getting this much-needed law through the legislature. 
ernments concerned. But if Chicago depends solely on this law, she will wait another century to get actual consolidation.

The garbage problem in cities under 100,000 can now be dealt with in a scientific manner if the councils in such cities use their new power to levy a special tax of two mills on the dollar to provide for the collection and disposal of garbage. The method, whether by reduction or incineration, is left entirely to the decision of each community.

The 49th General Assembly has to its credit a county tuberculosis law allowing county boards in all the counties of the state to levy a three-mill tax to provide a fund "to erect and maintain a county tuberculosis sanitarium" if the voters so order on a referendum vote at any general election. 


\section{APPENDIX D}

(The following notes are referred to by number in the corresponding chapters of the text)

\section{CHAPTER I}

(I) A lack of funds caused the office to be abolished in 1915 .

(2) Only the most important officials, as heads of departments or the "Mayor's Cabinet." Officials are not employces.

(3) H. A. Toulmin, "The City Manager," Appleton \& Co., is an excellent recent volume on this topic.

\section{CHAPTER II}

(I) Chicago City Manual, I915, p. I35.

(2) Defeated Apr. 7, I9I4.

(3) The time of regular council meetings was changed from evening to afternoon by an ordinance passed Oct. Io, I916.

(4) For non-partizan organization of the committees see note 28, pp. 224-25, Appendix D.

(5) Only true when Mayor and chairman are from the same political party. I9I6, Mayor Thompson, republican; chairman Richert, democrat.

(6) Appropriations from the Water Fund must always be added to estimates in the budget to find the total appropriations for that year. Note amount given for 1916, p. 19.

(7) Mayor Thompson issued a proclamation Oct. 4, I9I5, ordering the saloons of Chicago to be closed on Sunday according to the State law which had been a dead letter for many years. Order went into effect Oct. I0, 1915.

(8) Only two departments, Public Welfare and Public Service, have been added since 1913. See chart. p. 25.

(9) Four year term defeated Apr. 7, IgI4. 
(10) Department of Public Service was created by Council, Mar. 30, 1914. It includes bureaus of transportation, gas, telephone, electric and engineering.

(II) The new Municipal Pier, extending three quarters of a mile into the lake near Chicago Avenue, and containing ample facilities for all kinds of public recreation as well as docking privileges for lake boats, was opened in June, 1916. It is administered by the Harbor Board but under the commissioner of public works. The average daily attendance for July, 1916, was over 50,000 and for Sundays, over 250,000. These figures show the great possibilities of the pier for serving the people.

(i2) The name has been changed to Chicago and Cook County School for Boys: located just outside the city limits on part of the Gage farm. Buildings and site are provided by the city; Cook County provides the maintenance; the Chicago Board of Education provides the teachers and pays their salaries. It was dedicated Chicago Day, Oct. 9, 1916.

(13) A boys' court to try offenders between I7 and 2I years old was organized in 1915. It tries boys who are beyond the Juvenile Court age yet ought not to be thrown with hardened criminals. A Night Court is a recent addition and is proving very successful.

(14) Four infant welfare stations are now maintained in the congested districts.

(15) Clean Living, a monthly magazine on health, has recently been added to their preventive agencies.

(16) Required by act of legislature beginning Jan. I, I9I6.

(I7) Half a dozen comfort stations have at last been opened after a long campaign to secure these public conveniences. They are under the bureau of the health department.

(18) Under the auspices of the Y. M. C. A. twenty minute talks on hygiene are given during the winter months in the noon hour in car shops, factories and industrial plants all over Chicago. These talks are part of the educational work of the health department and are given by its members. 
(I9) Dr. John Dill Roberston was appointed health commissioner, April, I915, by Mayor William Hale Thompson.

(20) Dr. Drake is now Secretary of the State Board of Health. Appointed by Governor Dunne, Apr. I0, I9I4.

(2I) Fire Prevcntion School Readcr, Sept., 19I5, issued by state fire marshal department gives good material on this important subject.

(22) The official title is Chicago Normal College. It is located on the South side and the Normal furnishes about half of the teachers in the Chicago schools.

(23) Henry E. Legler, appointed Oct. 9, 1909.

(24) Since the map opposite p. 47 was prepared, four park districts have been added to the number of park governments in Chicago, making 16 in all.

(25) An act of the legislature, approved June 29, I9I5, provides for such consolidation of local governments in Chicago whenever the legal voters of the city so order at any election. The difficulty is to get the proposition on the ballot.

(26) Percentages are for I9I3, but practically true for I9I6.

(27) Progress is being made toward a genuinely scientific solution of this ancient problem. The Municipal Reduction plant is being rebuilt and soon will be one of the best in United States. An up-to-date garbage crematory has been built and is operated by convict labor at the Bridewell. A modern incinerator is being built at Ninety-fifth St. and new garbage boxes, trucks and loading stations are being installed over the entire city.

\section{NON-PARTIZAN ORGANIZATION OF COUNCIL COMMITTEES}

(28) Since 1902, the Chicago Council has been organized on a non-partizan basis of honesty and fitness. Council committees are made up by a committce on committees of six aldermen, two from each side of the city to represent the two leading parties. This committee on committees is elected in March by a caucus of the better aldermen. This caucus is called by the Municipal Voters 
League and the committee lists submitted by the committee on committees are reported to the new council after the April election. For fourteen years the council has approved these lists. The Municipal Voters League thus assumes the burden, which individual aldermen would naturally shrink from assuming, of excluding the socalled "gray wolf" element from a voice in making up these council committees. The great bulk of the work of the council is done in the committees. The Municipal Voters League is a non-partizan league of private citizens of twenty years' standing and the improved quality of the Council is largely due to its efforts.

(Above statement is from executive secretary of the league.)

\section{CHAPTER III}

(I) By annexation the Northwestern part of Evanston township to the City of Evanston in 1914, the whole of that township is now included in Chicago. The Southeastern corner of Ridgeville township has been annexed to Chicago. The remainder of Ridgeville township since July I7, I9I6, has been made the "Town of the City of Evanston" to provide a consolidated township for that city.

\section{CHAPTER IV}

(I) County commissioners are $e x$ officio also commissioners of the Forest Preserve District of Cook County, created by an act of legislature, I9I3, and approved by referendum vote, Nov. 3, 1914. A bond issue of $\$ 1,000,000$ was voted by the commissioners Mar. 5, 1915, for the purchase of forest districts.

(2) Change in party control caused her resignation, Dec. 22, 1914, in spite of notable work on the commission.

(3) Appropriations for 1916, \$13,182,000. Smaller building operations account for the decrease; but all department appropriations are larger.

(4) Legislature increased salary to $\$ 12,000$, but suit by the county to prevent payment of the increase is now before the State Supreme Court. 
(5) The Juvenile Psychopathic Institute under Dr. W. C. Healy conducts all these physical examinations and also tests any child thought to be subnormal.

(6) The new building was dedicated Mar. 4, 1915.

(7) By amendment to this law (July I, I9I5), alien widows who have taken first citizenship papers are eligible for a pension for their children under I4, born in this country. This change in the law has greatly increased the number of pensioners in Cook County.

(8) According to the report of the chief probation officer, Joel D. Hunter, 6,116 boys and girls were brought before the Juvenile Court during 1915.

(9) Established I915 with consulting staff of three alienists who serve without pay.

(10) To this large sum must be added the $\$ 27,400$ appropriated by the county board for outdoor relief in the country towns.

CHAPTER V

(I) A new assessment was made in 1915 .

(2) After 1916, the county collector cannot retain these fees but must turn them over to the county. (See pp. 73-74.)

(3) An amendment to the state constitution giving the legislature power to reduce and simplify the processes of taxation was voted on favorably on Nov. 7, 1916.

(4) The new "Town of the City of Evanston" was created by the County Board, July I7, 1916, and leaves all that remains of the Town of Ridgeville in Chicago.

(5) The district described here is popularly known as "the loop." It is one of the most valuable bits of property in the United States. The tax rates, 1915, for Town of South Chicago containing the loop:

\begin{tabular}{|c|}
\hline State \\
\hline County \\
\hline Sanitary \\
\hline City \\
\hline School \\
\hline Park \\
\hline
\end{tabular}




\section{CHAPTER VI}

(I) In Chicago, raised I9I5 to $\$ 7$ for each regular election day and $\$ 5$ for revision days, but the increase is being contested in the courts. Granted, Oct., I916.

(2) State convention of each party also nominates the presidential electors for their party.

CHAPTER VII

(I) The panel, or required number of jurors, either grand or petit, is obtained in Cook County from the jury commissioners, p. 82.

(2) The wonderful Fall River road and High Drive in Estes Park, Colo., are examples of convict-built roads of which Colorado is justly proud.

\section{CHAPTER IX}

(I) There has been no new reapportionment since I90I owing to political influence in the Legislature. See p. 99.

(2) Session Laws, 1915, p. 464.

(3) The 49th General Assembly, 1915, was dead locked six weeks over the election of a speaker. (Pp. 149-150.)

(4) Lawrence Y. Sherman is the first U. S. Senator chosen by popular vote in Illinois. He was reellected for the full six year term in Nov., I9I4. Term is from Mar. 4, I9I5, to Mar. 4, I92I. Senator Lewis' term expires Mar. 4, I9I9.

(5) "When the State Pays" and "Padding the Payrolls," the Assembly Bulletins issued by the Legislative Voters League, vol. 9, Nos. 24-25, are the best brief statements of such facts for the 49th General Assembly. Every civics pupil should make use of these valuable little bulletins of the L. V. L. issued monthly.

(6) The new law gave the Public Utilities Commission power to prohibit passes and they promptly forbade them within the state, to the joy of the railroads and the great disgust of the legislators.

(7) The 49th General Assembly, 1915, under the leadership of Speaker Shanahan reduced the number of standing com- 
mittees from 67 to 33 by altering the ancient house rules - a great gain toward more efficient law making.

(8) A salary raise to $\$ 3,500$ was passed in the session of 1915 . See note p. I43 on anti-pass ruling.

(9) Legislature of I9I5-I6. The three sessions of the 49 th General Assembly furnish a number of illustrations of the archaic system under which the Legislature of Illinois is organized. There were three sessions, one regular and two special, the latter made necessary by the careless wording of some of the large appropriation bills that had been "railroaded" through the last day of the session and afterward declared unconstitutional by the Supreme Court. The regular session in January began with the customary deadlock in the House over the election of a speaker. This deadlock lasted six wecks owing to the old struggle between the "wets and drys," neither side being willing to yield any point in this legislative duel and neither party seeming to consider the rights of their employers and paymaster, the people of Illinois, to their services as legislators. Late in February the deadlock was broken by the election of a so-called "wet" candidate, but a man with a reputation for justice and impartiality - a man respected by both sides. Under his leadership the ancient rules of the House were amended to reduce the seventy standing committees to thirty-three and the House payroll for janitors, watchmen and clerks was cut down to the smallest amount in ten years. But the Senate "padded its payroll" with an unusual number of "legless janitors and armless stenographers" until all the House economy was fruitless for the taxpayers. The special sessions, called by the governor in November and January, corrected their earlier blunders and also appropriated more money. The legislative "grist" in the shape of bills for the three sessions included some longsought reforms. Among them was a law for the registration of births and deaths; for permanent state care for the feeble-minded; a fixed salary for the treasurer of Cook County, all fees and interest to go to the county; a 
large number of park-and-playground bills and a "piecemeal" consolidation law for Chicago local governments. Appropriations totaled $\$ 46,000,000$, yet Illinois has no balance sheet. "Probably no state in the Union has appropriated money for government expenses with greater carelessness than has Illinois." But increasing tax rates are leading citizens to inquire "Where the money goes when the state pays." The 5oth session of the General Assembly [Jan., 19I7] has organized without the customary deadlock and elected a speaker of the House and president pro tem of the Senate promptly for the first time in a dozen years. The prospects are bright for the submission to the voters of Illinois of a constitutional convention resolution within two years. The majority party in the Legislature and the newly elected governor have pledged an "efficiency program" through reorganization of the state departments and revision of the archaic rules of procedure in both houses.

\section{CHAPTER $\mathrm{X}$}

(I) See pp. I4I-I42 for description of this deadlock.

(2) The state fire marshal's department is doing good educational work in fire prevention. (P. 37.)

\section{CHAPTER XII}

(I) This has been done in part through an amendment of 1906 to the state constitution.

(2) "The right of eminent domain is the right of the public to take private property for public use if just compensation is given the owner."

(3) Ch. III, towns and townships in Illinois.

\section{CHAPTER XIII}

(I) The reports for 1912 for Illinois and Chicago show better work in general than the more recent ones. I912 was a "reform year" along most lines of government work.

(2) This record has been sadly marred owing to the change in administration (April, I9I5) and the attempt to care 
for all "deserving friends" of the new mayor on the city pay-rolls.

(3) Miss Anna E. Nicholes, Secretary of the commission appointed by A. A. McCormick, Feb. I, I9I3, resigned Dec. 22, I9I4.

(4) Every citizen ought to study this report.

(5) These practical tests, made in I9I3, were begun under the presidency of W. B. Moulton whose able work on the civil-service commission set a high standard for the state. Recent political changes have weakened the work of the present commission.

\section{CHAPTER XIV}

(I) The board of administration has established an eight-hour day for all the employees, nurses and attendants in all state charitable institutions; also "equal pay for equal work" regardless of sex. The board has been a pioneer in these matters.

(2) The Institution Quarterly is the official organ of the Public Charity Service of Illinois and furnishes the best, most recent information on the service.

(3) Located on the Rock River near Dixon. Seven buildings are under construction. To be opened in the fall of rgi6.

(4) A new law for the "care and detention of feeble-minded" went into effect July I, I9I5. This law now recognizes mental defectives as wards of the state. See pp. 79-80 under Juvenile Court for Cook County.

(5) Since Jan. I, I9I6, a pension of $\$ 150$ a year is paid out of the county treasury to all blind adults without other income.

\section{CHAPTER XV}

(I) The number is constantly increasing owing to the creation of new park districts.

\section{CHAPTER XVI}

(I) For results of the law see reports of "„e Public Utilities commission.

(2) See p. I7o for definition and explanation of eminent domain.

(3) See Appendix C. 


\section{INDEX}

"After-supper" classes, 44.

Aldermen, salary, 6; term, 6. See Chicago and City Council.

Amendment Illinois constitution, 198-200, 202, 203.

American City Government, quoted, 4, 43 .

Assessor, county, 90, 9I ; town, 58, 9I, 92, 93.

Assessment property, 90-93.

Attorney, city, 13.

Attorney general, 157.

Auditor of public accounts, 157.

Australian ballot. See ballot.

Backyard proverbs, 34, 35 .

Ballot, description of, ro4-105; "little," I08; marking, 105-106; need of shorter, IIO; specimen, I04, 105.

Bartelme, Miss Mary E., 78.

Beaconsfield, Lord, quoted, 29.

Beard, Chas. A., quoted, 3-4, 43.

Bills, I45-148; enacting clause, I47.

Blind, care for, 194.

Board of, assessors, 90, 91, 182; education, 42, 169-170; equalization, 88; local improvements, 24 , 26; prison industries, II8-1 19 ; registry, IOI-IO2 ; review, 92, 93; school directors, I7I; visitors, I9I.

Bryce, quoted, I4.

Bureau of hospitals, baths, lodging-house, 32 ; legislative reference, 208; vagrancy, 39; vital statistics, 29-32; vocational supervision, 44,45 .

Cairo, 7, 56, I6r.

Camera squad, I4.
Capital punishment, II8.

Catherwood, Robert, quoted, I8oI8I ; I8I-I83, I84.

Change of venue, 59 .

Character - investigation department, I78-179.

Charity service of Cook County, 83-86.

Chart, Government of Chicago, 25; Government of Cook County, 87.

Chester, penitentiary at, II8.

Chicago, aldermen of, I8, I9; board of local improvements, 24, 26; Bridewell, 27; budget, 20; business agent, 24; city clerk, 23, 24; city collector, 23, 26 ; City Hall, 52, 68; city physician, 32 ; city treasurer, 24 ; civil-service commission, 23, I 77179; civic creed, 16 ; comptroller, 26; commissioner public works, 26, 27; Council, I8-20; custodian lost property, 4I-42; dead animals removed in, 3233; early history of, 15,17 ; fire department, 36-37; garbage, 26, 50; health department, 29-32 ; "home rule" for, 206; house of correction, 27; law department, 24 ; mayor, term, 20, powers of, I8, 20, 22, 23, salary, 20; meaning of, I7; parks, 46-49; police department, 38-4I ; population, 17, 70; problems of, 49-50; public library, 45-46; sanitary district, 50-53; school system, 4245; school lands, 42, 43, I66.

Chicago Bureau of Public Efficiency, $16,23,25,46,47,5 \mathrm{I}$, 69, 74, 87, I10, II2.

Chicago City Manual, I6, 4I. 
Chicago Fire, 37, I34, I36.

Chicago Historical Society, 16.

Chicago's Pocketbook, 2I.

Chicago Railways Company, 42.

Chicago State Hospital, 192.

Chief of police, $6,12,38$.

Child Labor Law, 2II-2I2.

Cities, officers of, 5; organization of, 5 and Villages Act, 4, 5, 10, I8; City civil service, I77-I79; City courts, 8 (See Municipal Courts).

City, attorney, I3; council, 6, I0, I8; government, outline of, 9I3; manager, $7,8$.

Civil-service commission, 6, I2, I76, I79-180; Chicago, I77-179; Cook County, I79, I84.

Civil service, history of movement, I76-I77; law, 52, 196, 207; meaning of, I76.

Clerk, city, IO-II ; county, 73, 75, 92, 94, 95; of elections, I02, I05, I07; town, 58 .

Clerks of the courts, 77 .

Cleveland, Grover, quoted, I75.

Coles, Gov. Edward, I35.

Collector, city, 6, I I, 90; county, $73-74,95,96$; town, 58, 95.

Comerford, Frank D., I40-I4I.

Commissioner public works, 6 , II, 26,27 ; health, 6, 12.

Commission plan city government, 6.

Committee men, I04.

Common law, I6o.

Comptroller, 6, II, 26, 73 .

Compulsory school law, I72, 2 II.

Congressional townships, 54, 6I, I69.

Constable, 59; Differences policeman and, 60 .

Constitution of 1870 , Illinois quoted, I47, I5I, I59, I65.

Constitutional convention, I98, 200.

Convergence of meridians, 62,63 .

Convict labor, I20.

Cook County, area, 68; board, 66, 70-7I; board of visitors, 86 ; budget, 72 ; charity service, $83-$ 86 ; clerk, $73,94,95$; comptrol- ler, 73 ; coroner, 74-75; courthouse, 68; government of, 7076 ; hospital, 83; infirmary, 58 , 83 ; judge, 80 , 85 , IOI ; juvenile court, 77-78; Juvenile Detention Home, 78 ; population, 68 ; president county board, 70, 7I-72; recorder, 75; sheriff, $72,73,74$; State Aid roads in, 204 ; State's attorney, 75-76; State courts in, $76-79$; superintendent of schools, 75, I66, I68-I69; surveyor, 75; treasurer, 73, 74, 91, 92.

Cook, Daniel P., 68, I36.

Corporations, taxation of, 88; public utility, 205, 206.

Cost of elections, III.

County, agent, 84, I8I ; assessor, 90 , 9I ; boards, 66, 203; commissioners, 66-67; government, faults of, 66-67.

Counties, area, 65 ; population, 65 ; work of, 65 .

Courts. See Judges.

Currey, J. S., I6, I7, 61, 63, quoted, I3I-I 32.

Cutting, Charles S., I2I.

Dead animals removed, 32-33.

Delinquent taxes, 95, 96 .

Deneen, Chas. S., I03, I52.

Detective bureau, 40.

Detention hospital, Cook Co., 80, 83-84.

Diagrams, Chicago's Pocketbook, 2I ; Chicago Public Safety departments, 34; Courts of Illinois, I60; Our System of Law, I59; Township with Sections numbered, 62 ; Subdivisions of a Section, 62.

Director public safety, 8 .

Dog-pound master, 39 .

Doolittle, Hon. J. R., quoted, I32.

Drake, Dr. C. St. Clair, photoplays by, 33; quoted, 35-36; model, "Breathing Dolls," 35.

Dram-shop law, 212.

Dr. Killjoy Was Right, 33 .

Dunne, Gov., quoted, 37, 156. 
Education, board of, 42, 169-170.

Election districts, 99, 100; in Cook Co., I38-139; officers, IOI.

Election commissioners, IOI.

Elections in Cook Co., 105; cost of, III.

Eminent domain, right of, 170, 207.

Equalization, board of, 88 .

Equity, r6r.

Error of Omission, 32, 33.

Evans, Dr., quoted, 29.

Evanston, assessment, 98; city of, 98, 177; director public safety, 8; school districts in, 62 ; town elections in, 56 .

Executive, state, I5I-I57; named, I5I.

Exempt from execution, property, II6; from taxation, 89 .

Fairlie, J. A., quoted, 56, 94.

Federal civil service, 176-177.

Fee offices Cook Co., I8I.

Finance committee, 19.

Fire-prevention day, 37 .

Fire marshal, 6, 12, 36.

Fitch, Geo., state rep., I46.

Foreign-born in Chicago, 49.

Forman, American Republic, 29, $50,54,65,74$.

Fort Dearborn, 16, 130-131.

Fresh-air crusade, 35-36.

Funds to parents, 78.

Garbage, Chicago, 26, 50; Sce Appendix $B$.

Garfield, Pres., 176.

Garner, J. W., Government in United States, 3, 88, 138, I5I ; quoted, Iog.

General Assembly, I38-r5o; apportionment of members, I38I39; committees, I43-I44; comparison, congress and, 49-50; disqualification of members, 140-I4I; employees, I42-I43; organization, I4I-I42; qualification of members, I40; rules of procedure, I44; salary, senators and representatives, I4I ; ses- sions, 143; speaker, I4I, I42, I43, I52; work of, I44-145.

Governor, I52-I55; appointing power, 152-153, 196; pardoning power, I54; veto power, I47I48.

Grand jury, II6, II7, I22.

Greene, E. B., 3, 9, 65, 88, I5I, 165, 188 (Government of Illinois), quoted, 194.

Guitteau, W. B., quoted, I59.

Health commissioner, 6, I2.

Health dep't, Chicago, 29-32; organization, 29-32.

Henderson, Dr. C. W., quoted, 209.

Higher education in state, 167r68.

Highway commission, 58, 203.

Hospitals, bureau of, 32 .

House of Correc :on, Chicago, 23.

How a bill becomes a law, 145I 48.

Hyde, H. M., quoted, 39.

Illinois, state of, I26; admitted to union, I3I ; area, I26; capitals, I34; charity law, I88-189; coal in, I28; constitutions, I32-134; constitution amendments, 198200, 202, 203; forests in, 127; history, 129-137; Indians, 128; latitude of, 126; map of congressional districts, I33; meaning of, 128; northern boundary, I3I-I32; physical features, 126; slavery, I35; under territorial government, 130; surface of, I27; waterways, I27.

Illinois and Michigan canal, I35.

Illinois moving forward, 20I-2I4. Illinois park commission, 2I0-2II. Illustrative material, I3, I4, 19, 23, 88; A Taxpayer's Calendar, 97, 98.

Indeterminate sentence, I I8.

Infirmary, 83, 195. See Oak Forest.

Initiative, 108, 109.

Inspection, food, 29; sanitary, 29. 
Inspectors of moral conditions, 40. Institution Quarterly, I88.

James and Sanford, 63, II3; quoted, I20-I2I.

Jefferson, Thomas, 61, I77.

Joliet, city of, 56 ; penitentiary at, I I8-I20; township of, 55 .

Judicial trials, II3-II8; civil, II3II6; criminal, II6-II8.

Judiciary, state, I59-164.

Judges, appellate, I00, I63 ; circuit, $76,77,99,163,164$; county, 8o, 85, IOI ; criminal court, 77 ; juvenile court, 77-78; municipal court, 27,28 ; probate court, 8082 ; superior, 76 ; supreme, I62163.

Judges of election, IOI, IO2.

Judson, Harry Pratt, Government of Illinois, 63.

June Law, 97.

Juries, II4, II5; differences grand and feit, I22.

Jurisdiction of a court, I6I-162.

Jurors, women, 80.

Jury commissioners, 82 .

Justice of the peace, 8,59 , II 4 , I24.

Juvenite court, report for I9I2, 79-Eo.

Juvenile Detention Home, 78, 84 .

Krutckoff, Chas., head clerk with Cook (o. board of assessors, 88.

Laboratory service, 30 .

Lawyers, I62.

Legislative reference bureau, 208209.

Legislative Voters' League, I46, I48-I49, I87.

Legislature of Illinois, I38-I50. See General Assembly.

Lewis, Hon. J. Hamilton, I4I.

Library, Chicago public, 45-46.

Library directors, I2, 22, 46.

Licenses, II, 24.

Lieutenant-governor, I4I, I5I, I56.

Lincoln, Abraham, I34.
Lincoln Memorial highway, 204.

Lincoln Park, 46, 48.

Lindsey, Judge Ben, 77.

Little ballot, I08.

Lobbying, I 47.

Local governments in Illinois, 65 .

Local improvements, board of, 24 , 26.

Local Option Law, 2 I 2.

Log-rolling, I47.

Long Nine, I34.

Lovejoy press riots, I35.

McCormick, A. A., pres. Cook Co. board, 7I, 72, I79.

McCleary, J. T., I I3, see Appendix $B$.

McCulloch, Catharine Waugh, 59; quoted, 20I-203.

McKinley, Wm., speaker, I4I.

"Madam, Who Keeps Your House?" 4.

Maps, Cook Co., showing townships, 69; Illinois, showing congressional districts, I33; Park districts of Chicago, 47; Sanitary district, $5 \mathrm{I}$.

Mayor, powers of, 6, Io. See Chicago.

Mental hygiene, rules of, 193.

Merit system, I75-I87; in city, I77-I79; in Cook Co., I79-184; in Illinois, I84-I87.

Minority representation, I39-140. Mothers' pension fund, 209, 210.

Moving-picture bureau, 40 ; theaters and films, 33, 40.

Municipal Coliseum Law, 207-208; courts, 27, 28, I6I ; ownership public utilities, 206-207; recreation, 46-49; Tuberculosis Sanitarium, 22, 34 .

Newell, M. H., article by, 54 .

Nicholes, Anna E., 7I, 83, I79, I84.

Non-township counties, 6o, 66, 91, I00, 195.

Oak Forest, infirmary at, 83 . 
Ordinance of 1787, I30; quoted, 165.

Outlook, The New York, article, $4 \mathrm{I}$.

Overseers of poor, 195 .

Owens, County Judge John E., 80.

Parents' pension fund, 78, 79, 209210.

Park districts, creation of, 48.

Penal institutions, II8-I20.

Pendleton Act, 176.

Pertinent questions, 14-15, 63-64, 8I-82, I24-I25, I50, I58, I73-174, I87.

Petit jury, 122.

Photo-plays, 33.

Pinckney, Judge Merritt W., 78.

Policeman, see Chicago; comparison with constable, 60; police magistrate, I3.

Police pension fund, 40.

Police women, 40.

Polls, see elections and ballot.

Poll-tax, 58, 204.

Poor relief, 194-I95.

Pope, Judge Nathaniel, I3I-I32.

Poster, 4 ; Clean Chicago, 31 ; Alcohol, 213.

Presidential preference vote, 108.

Primary elections, I03-IO4, 183.

Primary Law, 103, 183.

Prison industries, board of, II8II9:

Probate court, 80.

Probating a will, 80-82.

Probation officers, 77; adult, 8485.

Problems under township survey, 62.

Property exempt from taxation, 89.

Psychopathic Institute, 192, 193.

Public baths, 32.

Public education, I65-I73.

Public policy Law, Io9.

Public safety, 4I-42; bureau, 42; commission, 42; departments, 28-34; director, 8.

Public utilities commission, II9, 205-206.
Public utility certificates, 207.

Pullman strikes, 136-137.

Qualifications legal voter, I00, 200. Queen Victoria, 45.

Referendum, I08.

Registration, IOI-I02; by mail, 102.

Requisition papers, I55.

Restrictions on taxing power, 96, 97.

Review, board of, 92-93.

Ridgeville township, 56, 59, 70, 9I, 98.

River Forest, 7, 8.

Roosevelt, Theodore, quoted, 67 , I76.

Rural directors country schools, 75.

Sanitary district, 50-53; electricity generated by, 52 ; government of, 52 ; no civil service, 5253 ; salary trustees, 53.

Saturday Evening Post, quoted in Foreword for Teacher.

School administration, local, I69I70; directors, I7I ; funds, permanent, 166-167; township fund, 166; houses as polling places, I06; law, compulsory, I72; lands, 43; statistics, 43 ; tares. 165, 166; system of Illinors, summary by outline, I73; township trustees, I70-I7I.

School, John Worthy, 27.

Schools, high, I7I-I72; normal, I68; township high, I72; Little Mothers', 29; as social centers, 44.

Secretary of 'State, 156.

Sections, twp., 6I, 62 .

Senators, State, see Gencral Assembly; United States, election of, $56,108,141$.

Senatorial districts, 99, I38.

Sherman, Lawrence Y., I4I.

Sheriff, 72, 73.

Social centers, schools as, 44 . 
Social service department county court, 85 .

Soldiers' Homes, 194.

South Park board, 48, 49.

Speaker of house, see General Assembly.

Special assessments, II, 90, 95.

Spoils system, I76; how it works, I8I-I83.

Springfield, I35, I61, I62.

State aid good roads law, 203, 205; board of administration, I89, I90, I9I, I92, I96; charities commission, I89-I90, I9I ; charity service, I88-197; greatest need of, I95-I96; care of insane, I92; colony for epileptics, I9I, I93-I94; courts in Cook Co., 76-80; charitable institutions, location, 196-197; Eye and Ear Infirmary, 185; factory inspector, 2II; highway department, 203; hospitals for insane, I84-I85; institutions for children, I93; militia, I54-I55; school of St. Charles, 27, I94, I97; supreme court, I62-I63; superintendent public instruction, I68; Training School for Girls, 194, I97; University, I67I68.

Starved Rock, I29.

Streets, city, 3, 4.

Supervisor, town, 57, 58, 66, I95, 204.

Surgical Institute for crippled children, I90, I93, I97.

Surplus revenue fund, I67; State, I66-167.

Taxation, 88-98.

Tax warrant, 91, 92.

Teachers' pension fund, I72-I73.

Town of Chicago, I7.

Town, assessors, 58, 9I, 92, 93; clerk, 58 ; executive officers, 57 , 58 ; how formed, 55 ; judicial officers, 59; legislature, 56,57 ; meaning of terms, $54-55$; -meeting, 56,57 .

Towns, 54-6o.
Township, survey systems, $6 \mathrm{I}-63$; high schools, I72.

Townships in Cook County, 70.

Traffic squad, 39.

Treasurer, city, II ; county, 73, 74, 9I, 92 ; State, 156.

Treaty of Greenville, I6.

Trials, civil, II3-I I6; criminal, I I6-I I8.

Tribune, The Chicago, 16, 39, I46; quoted, I99, 200.

Tuberculosis, hospitals for, 84 .

Tuthill, Judge Richard A., 77.

Unearned increment land values, 43.

United States courts in Illinois, I6I.

Vagrancy, 39.

Ventilation, division of, 30 ; model to teach, 35 .

Veto power, governor, I47-I48; mayor, Io, 20-22; pres. Cook County board, 72 .

Village government, 8, 9; meaning of, 55 .

Visitors, board of, I9I.

Vital statistics, bureau of, 29-32.

Vocational supervision, 44, 45 .

Voting, see Elections and Ballot; machines, I09, IIO.

Wards, 5, 6; of Chicago, 18.

Wells, David A., quoted, II3.

West Park board, 48, 49.

Whiting, F. V., article by, 4I.

Whitman, John L., 27.

Woman's Auxiliary Mass. Civil Service Reform Ass'n, I75.

Woman's City Club of Chicago, 21, 43, see Appendix $B$.

Woman's Suffrage Law, 20I-203.

Workmen's Compensation Act, 209.

Writs, seven important, I22-I24; attachment, I24; certiorari, I23; habeas corpus, I22-123; injunction, I23; mandamus, I23; quo warranto, I23; replevin, I24.

Young, Ella Flagg, quoted, 42. 
4

$=$ 
THIS BOOK IS DUE ON THE LAST DATE STAMPED BELOW

\section{AN INITIAL FINE OF 25 CENTS} WILL BE ASSESSED FOR FAILURE TO RETURN THIS BOOK ON THE DATE DUE. THE PENALTY WILL INCREASE TO 50 CENTS ON THE FOURTH DAY AND TO \$1.00 ON THE SEVENTH DAY OVERDUE.

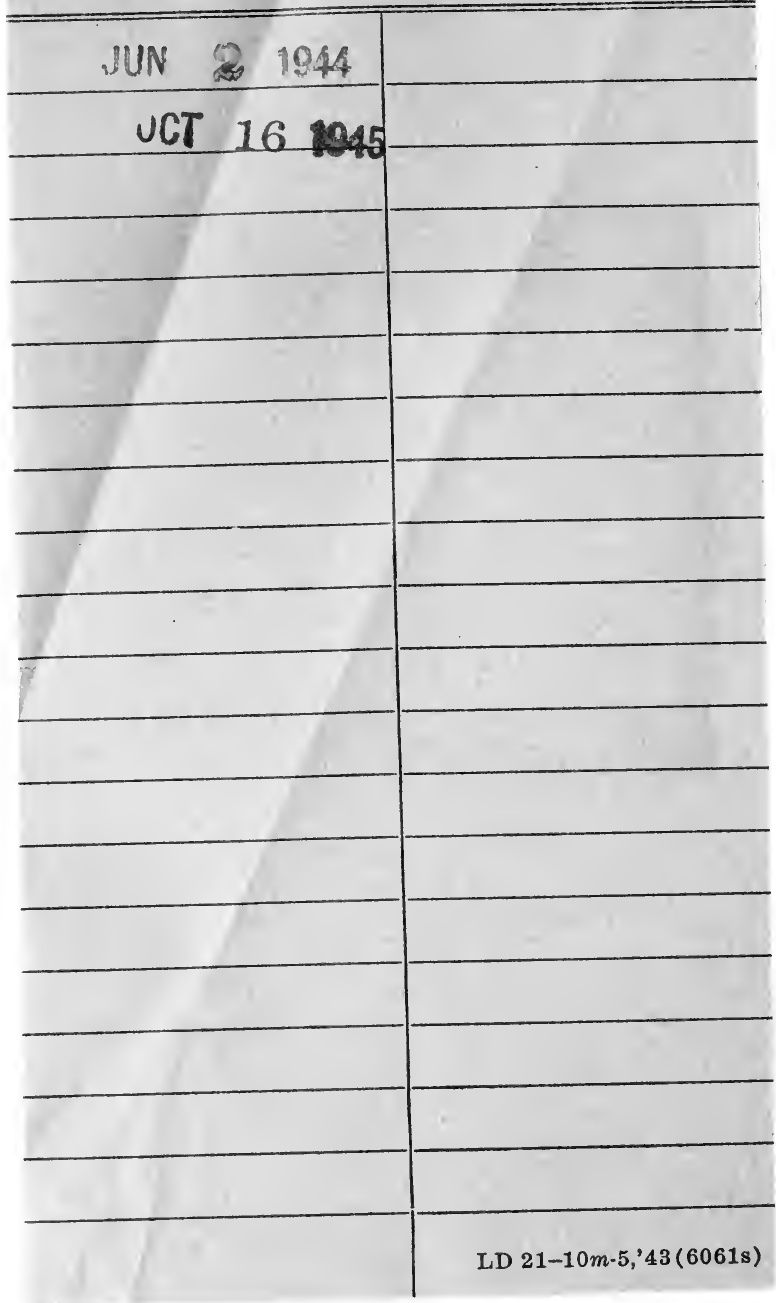


